\title{
Geology of the Selene perlite deposit in the northern Sierra Madre Occidental, northeastern Sonora, Mexico
}

\author{
Héctor Roberto Hinojosa-Prieto ${ }^{1, *}$, Jesús Roberto Vidal-Solano², Karl W. Kibler³, \\ Héctor Jesús Hinojosa-García ${ }^{4}$
}

${ }^{1}$ Universität zu Köln, Institut für Geologie und Mineralogie, Zülpicher Str. 49a, 50674 Köln, Germany.

${ }^{2}$ Departamento de Geología, Universidad de Sonora 83000 Hermosillo, Sonora, México.

${ }^{3}$ Prewitt and Associates, Inc. 2105 Donley Drive, Suite 400 Austin, Texas, 78758 USA.

${ }^{4}$ Science, Math \& Agriculture Division, Arizona Western College, Yuma, Arizona 85366 USA.

*hector.hinojosa@hotmail.com

\begin{abstract}
The Selene perlite ore deposit of northeastern Sonora, Mexico, lies at the southern edge of an extensive ( $85 \times 35 \mathrm{~km})$ assemblage of Early Oligocene-Miocene volcanic rocks. This fault-bounded and east-tilted volcanic assemblage is of variable composition and was erupted onto Cretaceous non-volcanic rocks. The volcanic ridge is located within the tectonically extended region of the northern Sierra Madre Occidental (SMO) silicic large igneous province. Geologic mapping reveals a faulted and uplifted bimodal volcanic sequence, dated as Late Oligocene, that contains more perlite outcrops than previously recognized and two new coplanar normal faults of Early Miocene age or younger that promoted the development of an adjacent, small half-graben filled by a volcaniclastic unit. The bimodal volcanic sequence comprises a basal Early Eocene rhyolitic lava and rhyolitic tuff overlain by a rhyolitic ignimbrite sheet, a middle flow-banded rhyolitic lava dome that hosts the Selene perlite flow, and the upper basalt on an erosional unconformity. The volcaniclastic unit rests in angular unconformity with the bimodal volcanic sequence, and was likely deposited in the Early Miocene. It comprises a lower fault breccia containing clasts of local eruptive products, a previously unidentified thin quartz arenite bed, and an upper, thick polymictic conglomerate containing clasts of perlite, rhyolite, andesite, and basalt. Potential sources for the bimodal (silicic and mafic) volcanic facies are distal and proximal-distal volcanic fissure vents, the locations of which were controlled by preexisting NW-SE and N-S normal faults and related fractures linked to the Mexican Basin and Range Extensional Province. This implies the bimodal volcanism to be synchronous with crustal extension, as recently shown for other areas of the SMO silicic large igneous province. Normal faulting in the area also influenced the formation, preservation, and exposure (uplift) of the Selene perlite flow. The structural discontinuities created a permeable uppermost crust that channeled meteoric water into the subsurface and promoted both the percolation and underground circulation of meteoric water and gases rising into the subsurface. The water-lava interactions led to the hydration of the flow-banded rhyolitic lava flow and the formation of huge amounts of perlite. The Selene perlite was partly preserved by the overlying basalt, but continued local normal faulting and subsequent erosion exposed the perlite ore at its current location.
\end{abstract}

Keywords: perlite, Sonora, synextensional volcanism, northern Sierra Madre Occidental, Mexico.

\section{Resumen}

El yacimiento mineral de perlita Selene del Noreste de Sonora, México, se encuentra en el límite sur de un extenso paquete de rocas volcánicas Oligoceno temprano-Mioceno. Este ensamble volcánico, limitado por fallas y basculado hacia el Este (85 x $35 \mathrm{~km}$ ), es de composición variable y fue emplazado sobre un basamento Cretácico. Este paquete volcánico se encuentra localizado dentro de una región tectónicamente extendida en la porción norte de la Gran Provincia Ígnea Silícica de la Sierra Madre Occidental (SMO). El mapeo geológico realizado en el área de estudio revela una sucesión volcánica de tipo bimodal y de edad Oligoceno temprano, 
que ha sido fallada y levantada. La secuencia contiene abundantes vestigios perlíticos y es cortada por fallas de a lo más una edad Mioceno temprano, que promueven el desarrollo de un semi-graben adyacente, rellenado por una unidad volcaniclástica. La secuencia volcánica bimodal comprende, a la base, tanto un derrame, como una toba de composición riolítica, que son cubiertos por un depósito ignimbrítico de edad Eoceno temprano. Un domo-colada de composición riolítica en la parte intermedia, hospeda a la perlita Selene y, un basalto en la parte superior cubre discordantemente a la secuencia. La unidad volcaniclástica, considerada Mioceno temprano, ocurre en discordancia angular sobre la secuencia volcánica bimodal. Esta unidad presenta, a la base, brechas de falla con clastos de volcánicas locales, una capa previamente no identificada de cuarzo-arenita y, en la parte superior, un potente conglomerado polimíctico, que contienen clastos de perlita, riolita fluidal, andesita y basalto. Las fuentes potenciales para los miembros máficos y félsicos del volcanismo bimodal se consideran puntos de emisión de tipo fisural y distal, y/o distal-proximal, que fueron controlados por fallas ligadas a la Provincia Extensional del Basin and Range. Esto implica que el magmatismo bimodal es sincrónico a la extensión cortical, tal y como recientemente se ha encontrado en otras áreas de la Gran Provincia Ígnea Silícica de la SMO. Además, el fallamiento normal del área influenció la formación, preservación y exposición del yacimiento de perlita Selene. Pero también, las discontinuidades estructurales presentes en la región crearon una corteza superior permeable, que canalizó agua meteórica en el subsuelo y promovió, tanto, la percolación y la circulación del agua subterránea, así como el ascenso de gases en el subsuelo. En esta región, la interacción de agua y lava riolítica dejo consigo la hidratación de los derrames riolíticos y la formación de grandes mantos de perlita. Particularmente en la localidad, la perlita Selene fue preservada por la extrusión de la unidad basáltica superior, pero el fallamiento normal y la erosión subsecuente expusieron el actual afloramiento del yacimiento en el área.

Palabras clave: Perlita, Sonora, volcanismo sin-extensional, Norte Sierra Madre Occidental, México.

\section{Introduction}

Perlite is a naturally occurring amorphous hydrated silicic volcanic glass of rhyolitic composition formed through secondary alteration by the slow diffusion of meteoric water into the glass/silica structure under low temperature surficial conditions (Ross and Smith, 1955; Marshall, 1961; Friedman et al., 1963; McArthur et al., 1998; Maxim et al., 2014). Through the hydration process, perlite retains between $2-5 \%$ water in the glass structure while maintaining its parental chemical composition (i.e., rhyolitic). The composition of the glass and the temperature of the environment control the rate of hydration (Friedman and Long, 1984). In the field, perlite is commonly distinguished by its vitreous, pearly luster, and concentric (conchoidal) fractures, with colors ranging from transparent light gray to glossy black. The geologic settings in which perlite occurs include the glassy parts of domes and lava flows of rhyolitic composition (Marshall, 1961); pyroclastic flows and ignimbrites (White and McPhie, 1997; McArthur et al., 1998); vitric tephra and the chill margins of dykes and sills (Davis and McPhie, 1996; Allen and McPhie, 2002; Orth and McPhie, 2003; Denton et al., 2009; Tuffen and Castro, 2009); and welded ash-flow tuffs (Koukouzas and Dunham, 1994; Tait et al., 2009; Denton et al., 2012). Perlite can transform (devitrify) into clays in response to low temperature metamorphism and/or hydrothermal activity (Marshall, 1961; Lofgren, 1970; Friedman and Long, 1984), but can also remain quite stable under surficial conditions for millions of years (Yamagishi and Dimroth, 1985; Davis and McPhie, 1996; McArthur et al., 1998). The rate of devitrification is a function of glass viscosity, which is mainly controlled by the water content and temperature
(Marshall, 1961).

Crude perlite ore can expand (“pop”) by a factor of 4 - 20 when rapidly heated to a suitable point (typically 760 $-1200{ }^{\circ} \mathrm{C}$ ) in an industrial expansion furnace to create a product referred to as expanded perlite (Doğan and Alkan, 2004; Ennis, 2011; Perlite Institute). Expanded perlite has various physical properties with commercial applications including high porosity, low thermal conductivity, low bulk density, high sound absorption, high heat resistance, high surface area, and chemical inertness or stability. These properties make expanded perlite adaptable to applications in several industries including construction (Topçu and Işikdağ, 2007, 2008; Zukowski and Haese, 2010; Sengul et al., 2011; Celik et al., 2014), chemical (Vaou and Panias, 2010), air (Gutarowska et al., 2014) and liquid filtration (Chakir et al., 2002; Torab-Mostaedi et al., 2011; Akkaya, 2012), horticultural (Daza et al., 2000; Acuña et al., 2013; Asaduzzaman et al., 2013), and petrochemical (Perlite Institute). The specific uses of expanded perlite in several industries are shown in Figure S1 in the Supplementary Figures section.

Perlite ore deposits occur worldwide and simple economics make open-pit mining operations the preferred practice for extraction. Crude perlite processing is restricted to crushing, drying, grinding, screening, sizing, and perhaps blending different grades of expanded perlite, all of which are commonly done at the mine site prior to shipment to expanding plants (Maxim et al., 2014; Perlite Institute). Expanded perlite production is completed in expansion furnaces. After preheating and heating, a suction fan pulls the expanded particles from the furnace and transfers them pneumatically to a cyclone classifier system. The classifier collects the expanded particles and removes excessively 
fine particles that do not expand. Expanded perlite can be manufactured to various densities (Austin and Barker, 1998) ranging from $32-240 \mathrm{~kg} / \mathrm{m}^{3}$, and can be produced in various grades (e.g., fine, medium, coarse) depending on the industrial application. Grain sizes vary by grade and producer and, contingent upon grade, can vary from $10 \mathrm{~mm}$ to as little as $\sim 20 \mu \mathrm{m}$ (Maxim et al., 2014; Perlite Institute). Chemicals are unnecessary in the processing and industrialization of crude and/or expanded perlite; thus leaving a modest environmental footprint relative to the quarrying and beneficiation operations for various other ores (Maxim et al., 2014; Perlite Institute).

The economic value, distribution, and surface extent of perlite ore deposits in the western North American Cordillera north of the US-Mexican border are well-documented, particularly in the states of Texas, New Mexico, Arizona, Colorado, Wyoming, Utah, Nevada, California, Oregon, and Washington (Huntting, 1949; Jaster, 1956; Zielinski, 1978; Wilson and Emmons, 1985), as well as in British Columbia, Canada (Rotella and Simandl, 2004). Conversely, Mexican perlite ore deposits immediately south of the border remain both geologically understudied and poorly understood despite their widespread occurrences within the silicic volcanic units of the Sierra Madre Occidental (SMO) silicic large igneous province. Nonetheless, Mexico has steadily produced perlite for nearly two decades (see Figure S2 in the Supplementary Figures section), although in low quantities relative to major world perlite producers such as Greece, China, Iran, Turkey, USA, Japan, Hungary, Italy, Russia, and the Ukraine, according to statistical data published by the British Geological Survey (BGS, 2004, 2007, 2010), Bide et al. (2014) at the BGS, the U.S. Geological Survey (USGS, 2005) and Bolen (2000, 2011a, 2011b, 2014, 2015) at the USGS. Perlite production in Mexico has been highly variable: it grew steadily from 1996 to 2002, boomed in 2003 and 2004 (reaching almost 200000 tons in both years), dropped in 2005, and has since plateaued (see Figure S3 in the Supplementary Figures section). Yet Mexico remains the largest and second largest perlite producer in Latin America and North America, respectively, according to the aforementioned statistics.

Mexican perlite ore deposits are commonly hosted in rhyolitic lava flows and ignimbritic strata of the Late Oligocene-Early Miocene SMO silicic large igneous province. From south to north, perlite ore deposits occur in the States of Puebla (Ugalde, 1970, 1975), México (Vivanco-Flores, 1978), Jalisco (Solis-Vorrath, 1984; Sánchez-González and Ramírez-Evangelista, 1996; 1997), Michoacán (Schmitter, 1951; Velasco-Hernández, 1976), Sinaloa (Mendoza-Cordova et al., 1989), Chihuahua (Hernández-Ávila, 2000), Durango (Rodríguez, 1961), Sonora (Bustillo-Sáynez and Gómez-Gutiérrez, 1965; Lagarda-Lagarda, 1983; Almazán-Holguín and TrellesMonge, 1986; Palafox-Reyes et al., 1998; Arriaga-Meléndez et al., 2008), and Baja California Norte (Corral-Gastélum et al., 1999; Staude and Barton, 2001; Cobo-Rivera et al.,
2010). The Selene perlite ore deposit, formerly known as Babidanchic perlite (Almazán-Holguin and Trelles-Monge 1986; CRM, 1994; Palafox-Reyes et al., 1998), occurs along the tectonically extended western edge of the northern SMO in northeastern Sonora, Mexico (Figure 1). The SMO is one of the largest silicic igneous provinces in the world (Bryan and Ferrari, 2013). The Selene perlite ore deposit received its name following a new mining claim undertaken by two independent prospectors. To document this deposit, we used traditional geological mapping within an area of $4 \times 4$ $\mathrm{km}$ combined with petrographic analysis of representative volcanic samples of rhyolitic and basaltic composition, and local lithostratigraphic correlations with well-dated volcanic units of rhyolitic composition. The objective was to define the occurrence of the deposit and understand its volcanogenic context and formation process.

\section{Regional Tectonomagmatic Setting}

Tectonomagmatic processes have shaped the state of Sonora since at least the Proterozoic (González-León et al., 2011 and references therein). Subduction of the oceanic Farallon plate beneath the continental North American plate as early as the Middle Cretaceous was responsible for the Late Cretaceous-Paleogene arc plutonism and cogenetic volcanism of northwestern Mexico, and the resulting compressional Laramide orogeny (ca. 90 - $40 \mathrm{Ma}$ ) (McDowell and Keizer, 1977; Aguirre-Díaz and McDowell, 1991; McDowell et al., 2001; Ferrari et al., 2007). The Late Cretaceous-Early Cenozoic Laramide magmatic arc of Sonora (González-León et al., 2011) was followed by a 6 m.y. magmatic hiatus (Valencia-Moreno et al., 2001). The once horizontally subducting Farallon plate either rolled back or detached (Humphreys, 1995; Ferrari et al., 2007) leading to the westwards migration of magmatism and a period of intense volcanism known as the Early Oligocene and Late Oligocene-Early Miocene ignimbrite flare-ups (at ca. 34 - 24 and $24-18 \mathrm{Ma}$, respectively; McDowell and Keizer, 1977; McDowell and Clabaugh, 1979; Cameron et al., 1980; Demant et al., 1989; Armstrong and Ward, 1991; Ferrari et al., 2007). During these magmatic episodes rhyolitic and lesser basaltic and andesitic lavas were emplaced in a supracrustal regime already undergoing extension (AguirreDíaz and McDowell, 1991; Bryan et al., 2008; Ferrari et al., 2013; Murray et al., 2013). This bimodal volcanism built vast parts of the SMO from the USA-Mexico border as far as south-central Mexico, and was partly concurrent with high-angle normal faulting associated with the Basin and Range Extensional Province (BREP) and with low angle faulting producing metamorphic core complex (MCC) formation in the Late Oligocene (Nourse et al., 1994; Gans, 1997; Staude and Barton, 2001; Dickinson, 2002; VegaGranillo and Calmus, 2003; Ferrari et al., 2007; Bryan et al., 2008; Wong et al., 2010; Ferrari et al., 2013; Murray et al., 2013). North of latitude $\mathrm{N} 22^{\circ}$, the Farallon plate 

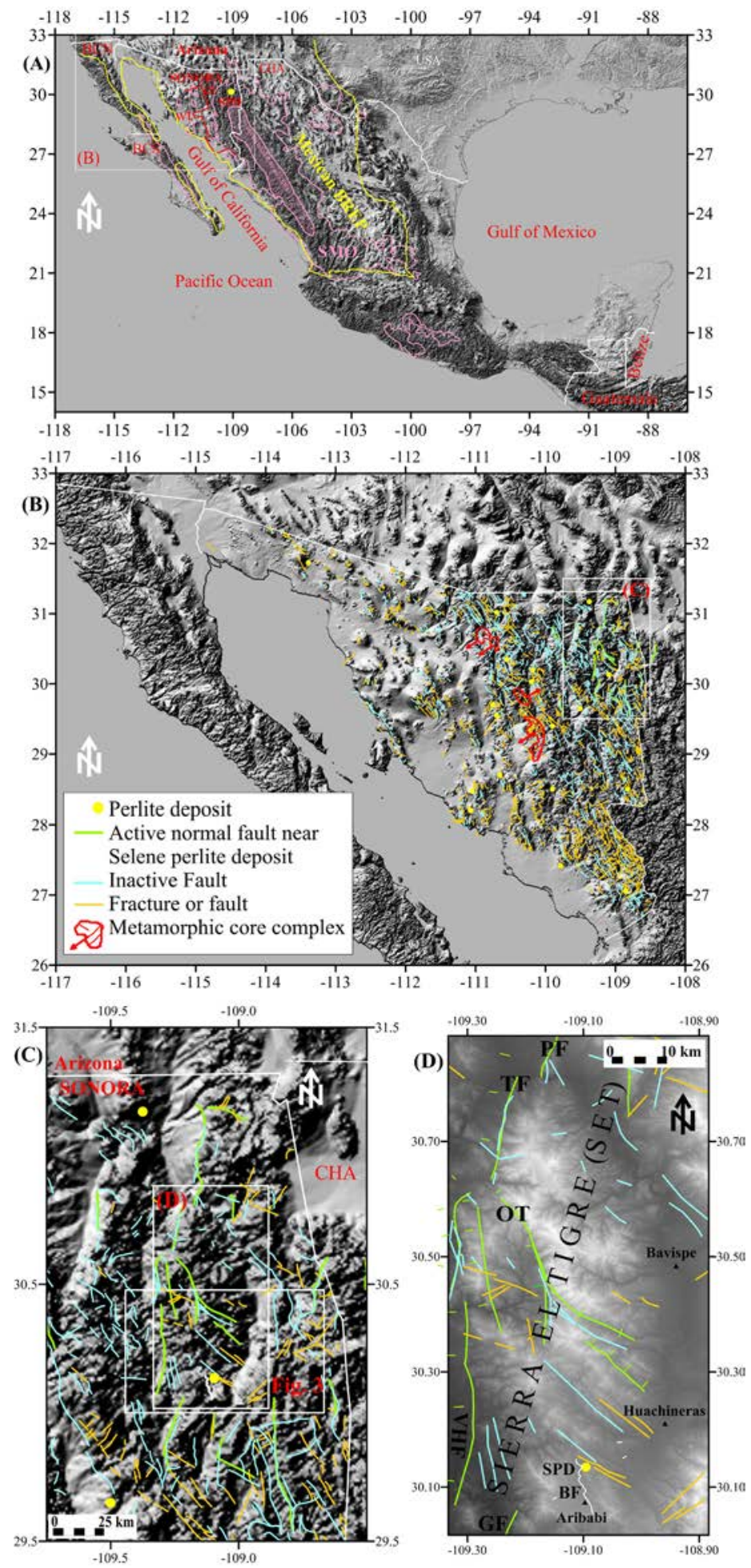

Figure 1. Terrain Map of Mexico showing the distribution of the Sierra Madre Occidental (SMO) silicic large igneous province (pink), the Mexican Basing and Range Extensional Province (BREP) (yellow), and the west-tilted (wt) and east-tilted (et) domains in Sonora divided by the red line (after Gans, 1997) (A). Shaded area inside the SMO corresponds to the unextended core of the SMO. SPD-Selene perlite deposit (in A and D); BCN-Baja California Norte; BCS-Baja California Sur; CHA-Chihuahua. Map in (A) compiled after Henry and Aranda-Gomez (1992); Gans (1997); Staude and Barton (2001); Ferrari et al. (2007); and Bryan et al. (2008). Distribution of Sonoran perlite ore deposits and main structures (B). Note close proximity between normal faults and fractures relative to perlite localities. Metamorphic core complex (MCC) with slip-vector (black arrow) after Nourse et al. (1994); Vega-Granillo and Calmus (2003); Hines and van der Pluijm (2008, 2012); and Wong et al. (2010). Close-up of northeastern Sonora showing active (Suter, 2008a, 200b, 2015; Castro et al., 2010; Villalobos-Escobar and Castro, 2015) and inactive (Arriaga-Meléndez et al., 2008) normal faults and related fractures around the Sierra El Tigre (SET) (C). Close-up of the SET showing the location of the Selene perlite prospect relative to the Babidanchic normal fault, population centers, and NS-trending active and NW-SE-trending inactive normal faults and related fractures (D). PF-Pitáycachi fault; TF-Teras fault; OF-Otates fault; VHF-Villa Hidalgo fault; GF-Granados fault; BF-Babidanchic fault. 
subducted completely beneath the North American plate by the Early-Middle Miocene (Lonsdale, 1991). The end of subduction and the onset of rifting produced transitional and tholeiitic magmatism with icelanditic and peralkaline flows throughout the region (Vidal-Solano et al., 2005, 2007, 2008a, 2008b; Calmus et al., 2011), and initiated the opening of the Gulf of California. Beginning at $c a$. $30 \mathrm{Ma}$, the complete Pacific-Farallon ridge came in contact with the North America plate. Ever since, the Pacific-North America boundary has evolved through the migration of triple junctions along the coast, so that the whole margin from southern Baja California to Cape Mendocino becomes a dextral transform boundary (Atwater, 1970; Atwater and Stock, 1998; McQuarrie and Wernicke, 2005). However, diffuse crustal extension across the Basin and Range province of Mexico was still active and headed the extension in the Gulf of California (McQuarrie and Wernicke, 2005; Bryan et al., 2013; Ferrari et al., 2013; Bennett and Oskin, 2014). Recent regional geologic studies demonstrate that the Gulf of California began to rift between the Late Oligocene to Early Miocene (Bryan et al., 2013; Ferrari et al., 2013; Duque-Trujillo et al., 2014a, 2014b), and extension became narrower at $c a .20-18 \mathrm{Ma}$ and again after $c a .12 .5 \mathrm{Ma}$ when kinematics of rifting became more oblique and strike-slip faults started to developed (Ferrari et al., 2013; Bennett and Oskin, 2014; García-Martínez et al., 2014). The active tectonic regime shaping the Gulf of California is defined as a narrow, NNW-trending dextral transtensional belt of strike-slip faults connecting en echelon pull-apart basins all kinematically linked to the strike-slip San Andreas Fault system (Ferrari et al., 2013; Bennett and Oskin, 2014).

\section{Perlite deposits in Sonora}

The exact surficial exposure and geologic interpretation of individual perlite occurrences are not only relevant to assessing the economic potential and quality of a given perlite ore deposit, but also to an understanding of their formational process (e.g., whether perlites form by a common or different processes during a single or multiple episodes). Figures 1 A-B show the location of the Selene perlite prospect and the distribution of some known perlites in Sonora relative to the geographic extent of the SMO silicic large igneous province. Our current geologic understanding of individual perlite localities is poor and the literature is limited to a few unpublished technical reports and bachelor's theses (Bustillo-Sáynez and GómezGutierrez, 1965; Lagarda-Lagarda, 1983; Almazán-Holguin and Trelles-Monge, 1986; CRM, 1994). Up to now, a total of 19 perlite localities have been identified in the State of Sonora (Figure 1B), all of which remain undated and some nameless. Radiometric ages of nearby silicic rocks of rhyolitic composition, which are (tentatively) correlative to the rocks that host perlites, provide clues about the age of the hosting rock(s), and hence, the minimum age of perlite formation.

Since at least Late Oligocene times, crustal extension and decompression-driven mantle and crustal melting have been the dominant tectonomagmatic factors influencing western Mexico (Bryan et al., 2013; Ferrari et al., 2013; Murray et al., 2013, 2014; Murray and Busby, 2015). Erosion has removed vast amounts of Laramide-related igneous rocks down to their plutonic roots, especially in central and western Sonora. In general, perlite occurrences in eastern and southern Sonora are hosted in lava flows, domes, and ignimbritic strata of rhyolitic composition, all linked to the Late Oligocene-Early Miocene SMO silicic large igneous province. However, perlites in central and western Sonora (Lagarda-Lagarda, 1983; CRM, 1994) are typically hosted in Early to Late Miocene ignimbritic and peralkaline rhyolites associated with the intra-continental rifting of the proto-Gulf of California (Vidal-Solano et al., 2005, 2007, 2008a, 2013, 2014a, 2014b). The distribution of perlite ore deposits in Sonora is such that (i) they occur along the western margin of the northern SMO as far as the coast, (ii) they are in proximity to extensional faults and related fractures, and (iii) they sometimes contain zeolite and puzzolana beds (CRM, 1994) indicative of different devitrification histories.

\section{Geologic Setting}

The Selene perlite ore deposit occurs at $1350 \mathrm{~m}$ above sea level and is located on the southern edge of the Sierra El Tigre (SET) (Figures 1 C-D) within the Nacozari Mining District (Palafox-Reyes et al., 1998). The SET is an ovalshaped ( $85 \mathrm{~km}$ by $\sim 35 \mathrm{~km}$ ), uplifted and east-tilted (by normal faulting) volcanic edifice composed of thick Early Oligocene-Miocene andesitic, rhyolitic and basaltic lavas, rhyolitic ignimbrites, and lesser trachitic lavas erupted onto pre-Cretaceous non-volcanic rocks (SPP, 1987; CRM, 1994; Palafox-Reyes et al., 1998). The SET is located in the extended portion of the northwestern SMO silicic large igneous province (Figure 1), the thick bimodal volcanic sequence belonging to the Upper Volcanic Supergroup (e.g., McDowell and Keizer, 1977; Demant et al., 1989; Palafox-Reyes et al., 1998).

The geology around the Selene perlite prospect is dominated by: (i) a Late Oligocene volcanic package composed of basalts, rhyolites, rhyolitic ignimbrites, and minor andesites; (ii) Miocene basaltic lava flows and terrestrial clastic rocks; and (iii) Quaternary alluvium (Figure 2). Most of the Late Oligocene volcanics dip $10-$ $30^{\circ} \mathrm{ENE}$ with small variations to the NNE, whereas most of the Miocene basalts and clastic rocks (conglomerates and sandstones) dip $3-30^{\circ} \mathrm{WNW}$ (SPP, 1987; Palafox-Reyes et al., 1998). The Miocene basalts are interstratified with conglomerates that resemble those of the Miocene Baucarit Formation, which fill syndepositional extensional basins across Sonora (McDowell et al., 1997). 


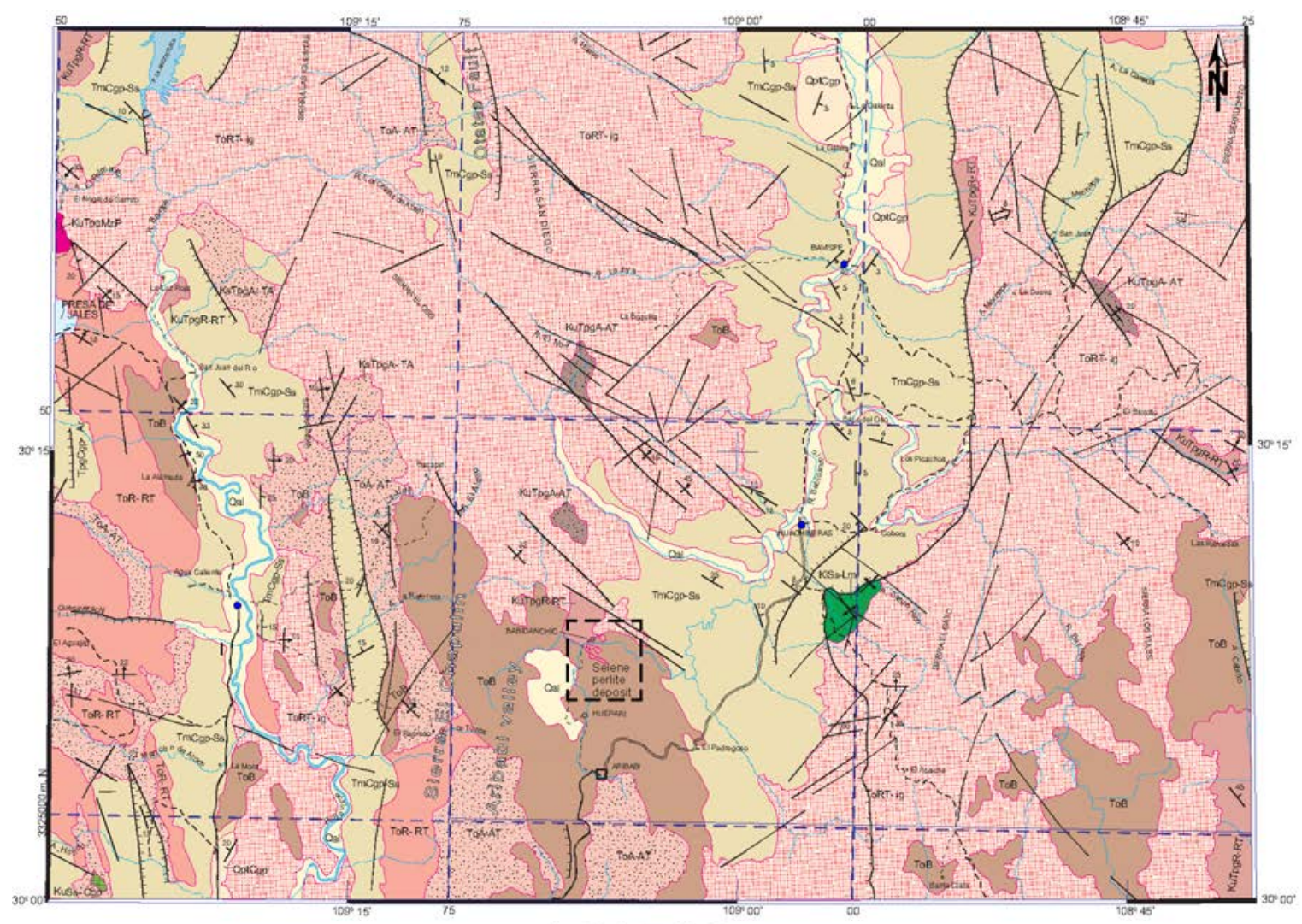

LE GEN D

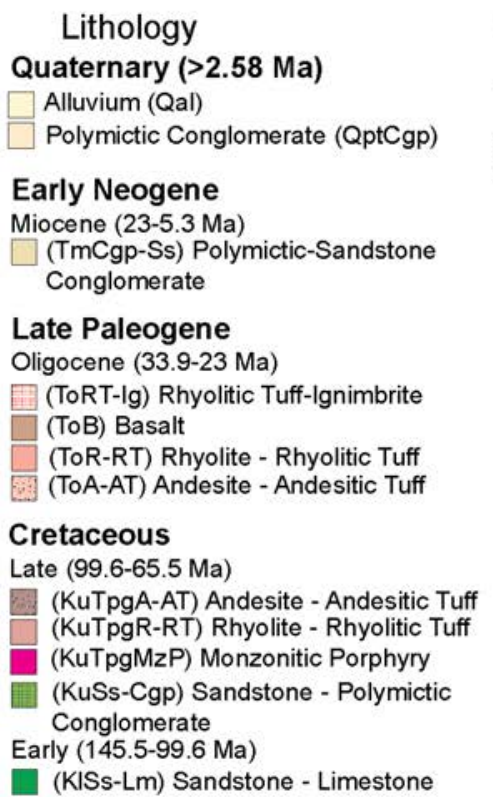

Geologic Structures

Symbols
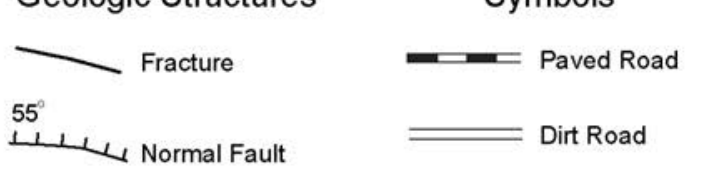

Regional Fractures $(\mathrm{N}=127)$
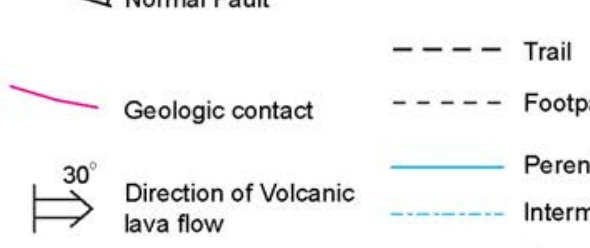

(TmCgp-Ss) Polymictic-Sandstone Conglomerate

Late Paleogene

Oligocene (33.9-23 Ma)

(ToB) Basalt

(ToR-RT) Rhyolite - Rhyolitic Tuff

(ToA-AT) Andesite - Andesitic Tuff

a (KuTpgA-AT) Andesite - Andesitic Tuff (KuTpgR-RT) Rhyolite - Rhyolitic Tuff (KuTpgMzP) Monzonitic Porphyry

(KuSs-Cgp) Sandstone - Polymictic Conglomerate

(KISs-Lm) Sandstone - Limestone
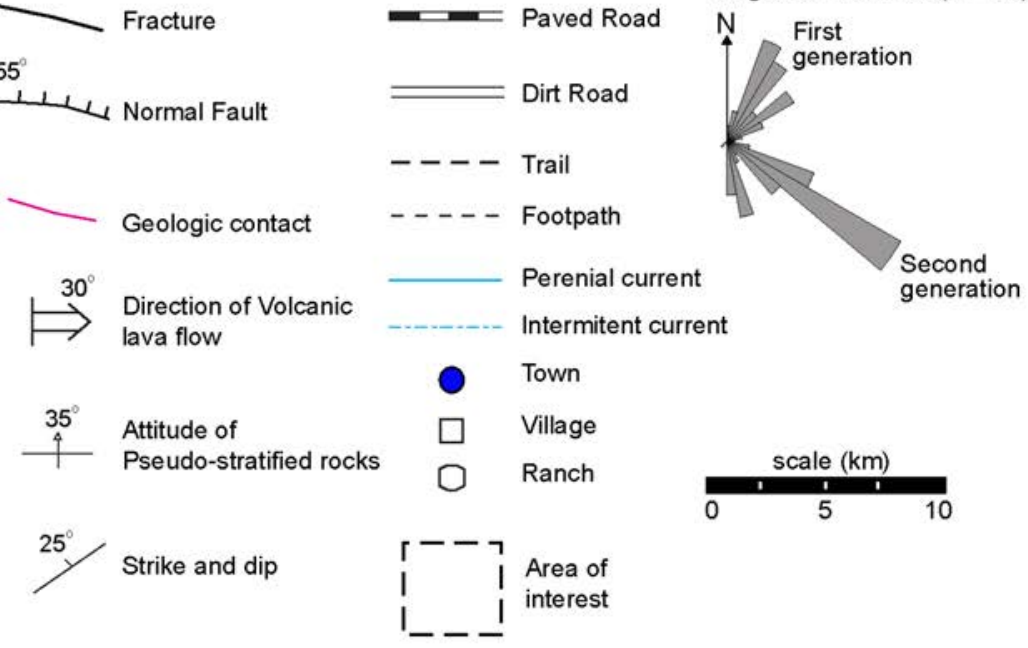

Figure 2. Regional structural geologic map of the southern half of the SET and surroundings (modified after SPP, 1987; Palafox-Reyes et al., 1998). The Selene perlite prospect occurs in the southern tip of the SET.

The main geologic structures around the Selene perlite prospect are 5 to $60 \mathrm{~km}$-long, $\mathrm{N}-\mathrm{S}$ and NW-SE normal faults and associated 2 to $16 \mathrm{~km}$-long, NW-SE fractures/ fissures that affect Late Oligocene rhyolitic lava flows and rhyolitic ignimbrites (Figure 6) and are linked to the Mexican BREP (Palafox-Reyes et al., 1998). Various north-south, west-dipping normal faults bound long, narrow half-graben basins filled by polymictic conglomerates and lesser sandstones of Miocene age (Figures 1 A-D and 2). The Selene perlite prospect is bounded to the west by a valley, in turn bounded by an uplifted Late Oligocene volcanic ridge comprised of andesitic lavas and tuffs, and subordinate 
rhyolitic lavas (Palafox-Reyes et al., 1998) named the Sierra El Chapulín (Figures 3 A-B) in the topographic chart of the Instituto Nacional de Estadística y Geografía (INEGI, 2005). It is bounded to the east by a $\sim 120 \mathrm{~km}$-long by $~ 13$ $\mathrm{km}$-wide, N-S trending (synextensional?) half-graben that wraps around the eastern slopes of the SET (Figures 1, 2 and 3 A-B). The NNW-SSE-trending Sierra El Chapulín is $11 \times 5 \mathrm{~km}$, and is bounded to the west by a $\sim 27 \mathrm{~km}$ - long by $\sim 2.5 \mathrm{~km}$ - wide N-S-trending sedimentary basin. All the active and inactive normal faults around the Selene perlite prospect are linked to the Mexican BREP (PalafoxReyes et al., 1998; Suter, 2008a, 2008b; Castro et al., 2010; Rascón-Heimpel et al., 2012; Villalobos-Escobar and Castro, 2015; Suter, 2015) and controlled the synextensional deposition of Miocene volcaniclastic units and Quaternary alluvium across the area. Recent seismological monitoring around the SET shows rather low levels of seismicity within and around the Selene perlite prospect compared to levels of seismicity beyond the prospect scale (Castro et al., 2010; Villalobos-Escobar and Castro, 2015). These seismological studies reveal three north-south-striking, steeply west-dipping, seismically active normal faults within $\sim 25$ to $100 \mathrm{~km}$ north of the Selene perlite prospect, and two coplanar faults farther south ( 25 to $45 \mathrm{~km}$ ) (Castro et al., 2010; Villalobos-Escobar and Castro, 2015) (Figures 3 B-C). The northern normal faults (from closest to farthest) correspond to the active Otates ( $28 \mathrm{~km}$ - long), Teras ( 21 km- long), and Pitáycachi ( 42 km- long) faults (Castro et al., 2010; Villalobos-Escobar and Castro, 2015) that ruptured during the 3 May $1887 M_{\mathrm{w}} 7.5$ earthquake (Suter, 2001, 2006, 2008a, 2008b, 2015; Suter and Contreras, 2002). The southern faults are the active Villa Hidalgo and Granados normal faults of comparable length (Castro et al., 2010; Villalobos-Escobar and Castro, 2015). Hence, the Selene perlite ore deposit clearly formed in a volcanogenic setting that has undergone crustal extension since the Late Paleogene. This implicates permeability in the uppermost crust.

\section{Geology of Selene perlite prospect}

Almazán-Holguín and Trelles-Monge (1986) investigated the Selene perlite prospect; however, they only focused on the westernmost exposed perlite body and left other bodies unexplored. They reported the following lithostratigraphic sequence: (i) a basal $200 \mathrm{~m}$ thick lava of andesitic to basaltic-andesitic composition of inferred Upper Cretaceous age; (ii) a $120 \mathrm{~m}$ thick pyroclastic unit of inferred Paleocene-Eocene age comprising a lower, thin, pink lithic tuff; a middle, thin, reddish-brown vitrophyre; and an upper, very thick pinkish-brown ignimbrite; (iii) a $120 \mathrm{~m}$ thick rhyolite with aphanitic texture that grades locally into light-to dark-gray perlites of inferred Oligocene age; (iv) a capping, $90 \mathrm{~m}$ thick, dark-brown, amygdaloidal basalt of inferred Late Oligocene-Miocene age, flanked by
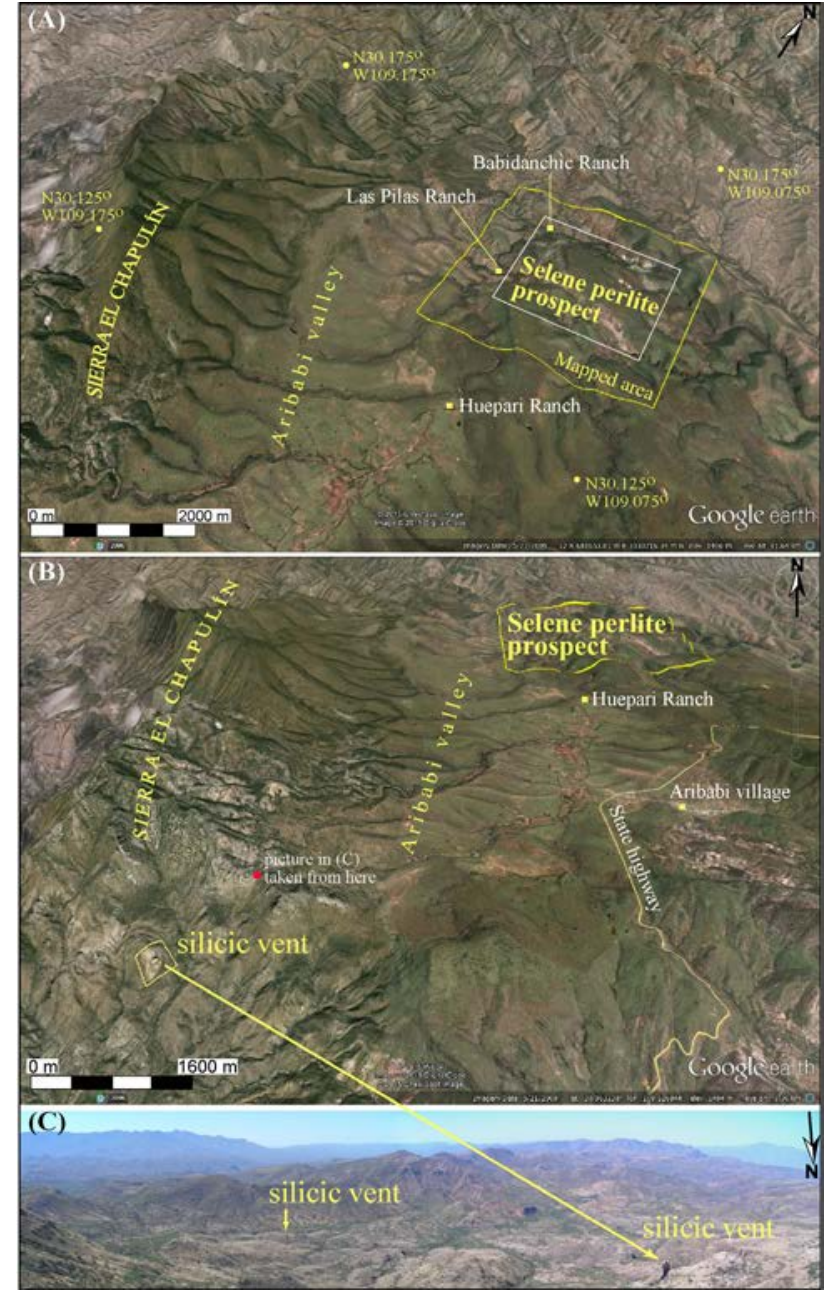

Figure 3. Oblique satellite views toward the northeast showing the mapped area of the Selene perlite prospect (A) and toward the north displaying the location of vertically-oriented resistant silicic intrusions (B) interpreted as vents with respect to the mapped area. Representative panoramic field photograph viewing toward the south highlighting the interpreted silicic vents (C). Satellite images from Google Earth ${ }^{\circledR}$ with $2 \times$ vertical exaggeration.

a $120 \mathrm{~m}$ thick well-consolidated agglomerate containing clast of andesites, rhyolites, basalts, and pyroclastic rocks of inferred Miocene-Pliocene age; and (v) Quaternary alluvium ( $5 \mathrm{~m}$ thick) composed of an unconsolidated mixture of clay, mud, sand, and gravel deposits derived from local volcanic sources. They reported only two wellexposed perlitic bodies, which are labeled $I$ and $I I$ in our geologic map (Figure 4). Our new mapping identifies some differences, likely due to our larger map area.

We mapped the Selene perlite ore deposit using the 1:50000 scale Villa Hidalgo (H12-B86) topographic map published by INEGI (2005). Our mapping revealed six exposed perlite ore bodies outcropping within an area of $\sim 6.3 \mathrm{~km}^{2}$ and here referred to as $I$ to $V I$ (Figures 4 and 5A). We also mapped a silicic and mafic volcanic and volcaniclastic unit, and two previously unrecognized faults, here named the Babidanchic and Selene faults (Figure 4). 


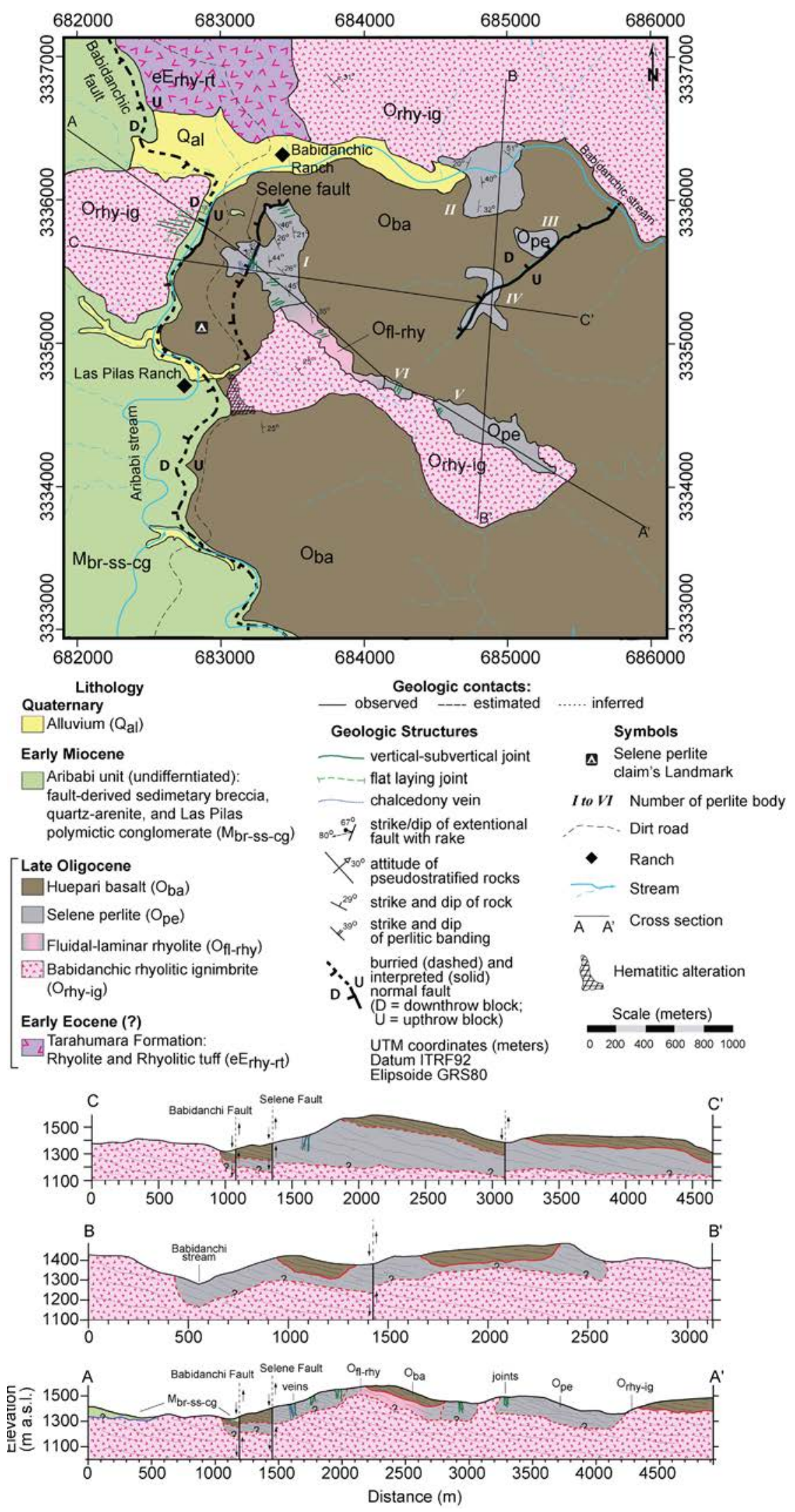

Figure 4. Geologic map of the Selene perlite prospect and cross sections (AA', BB' and CC'). SMO-Sierra Madre Occidental. The Roman numerals $I$ to VI correspond to the number of the perlite body referred in the text. 

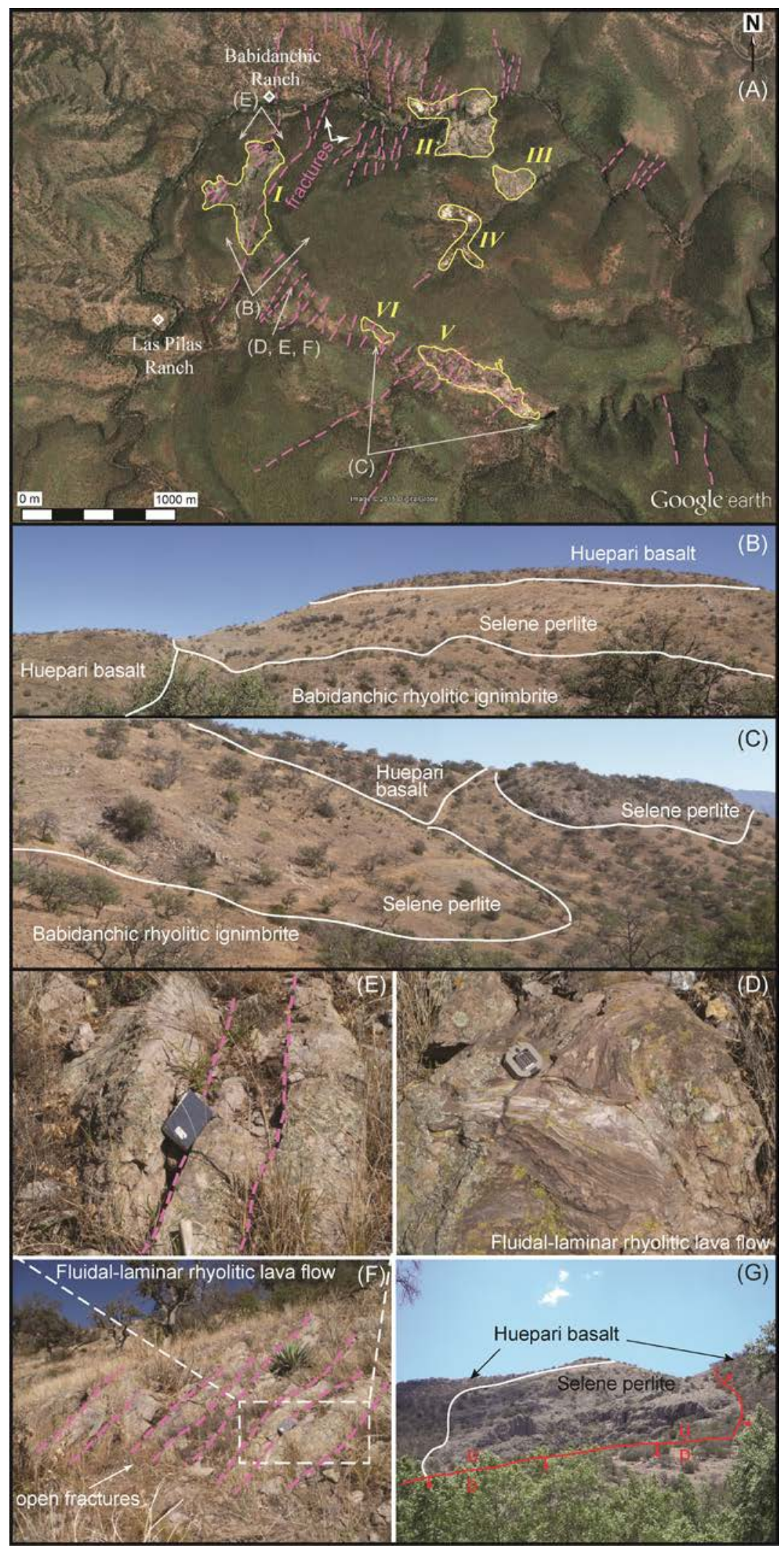

Figure 5. Satellite image of the Selene perlite bodies labeled in Roman numerals (A), representative field photographs of the Selene perlite flow relative to its bounding silicic and mafic volcanic units (B-F), and the cross-cutting Selene normal fault whose surface trace shown in red (G). Satellite image from Google Earth ${ }^{\circledR}$ with no vertical exaggeration. 
From bottom to top, the lithostratigraphy includes (Figure 6): (i) a basal early Eocene sequence of rhyolitic lavas and rhyolitic tuffs (see Almazán-Holguín and Trelles-Monge, 1986; Palafox-Reyes et al., 1998); (ii) an ignimbrite sheet, here informally named the Babidanchic rhyolitic ignimbrite; (iii) a flow-banded rhyolitic lava flow, which hosts (iv) the Selene perlite flow; and (v) a ubiquitous basaltic lava flow, here informally named the Huepari basalt, erupted on an erosional unconformity. This is, in turn, covered along an angular unconformity by a newly discovered volcaniclastic unit, previously mapped as Quaternary alluvium and Oligocene basaltic lavas (Palafox-Reyes et al., 1998) and here informally named the Aribabi unit (after Aribabi village), which comprises three members: (vi) a basal fault breccia (previously identified by Almazán-Holguín and Trelles-Monge, 1986), (vii) a middle, thin ( $1 \mathrm{~m})$ quartz-arenite bed, and (viii) an upper, very thick, pervasive polymictic conglomerate, here termed the Las Pilas polymictic conglomerate (after Las Pilas Ranch). Overlying all units is (ix) a thin $(\leq 5 \mathrm{~m})$, unconsolidated, poorly sorted layer of Quaternary alluvium composed of mud, sand, gravels, and boulders of silicic and mafic composition deposited along stream beds (see Almazán-Holguín and Trelles-Monge, 1986; Palafox-Reyes et al., 1998).

\subsection{Volcanic and Volcaniclastic Lithofacies}

\subsubsection{Volcanic units}

Babidanchic rhyolitic ignimbrite: This $~ 180 \mathrm{~m}$ thick, silicic volcanic unit is well exposed along a $\sim 3 \mathrm{~km}$ - long NW-SE trending gully flanking the southern edge of the Selene perlite ore bodies $I, V$, and $V I$ (Figures 4 and 5 B-C). Hematitic alteration is evident in the field as small red zones best exposed next to the Babidanchic fault (Figure 4). Dykes, sills, and/or hypabyssal intrusions were not observed. Petrographic observations demonstrate a pyroclastic eutaxitic texture with a spherulitic vitreous, fluidal, porphyritic devitrified matrix (Figure 7), and corroborate previous petrographic observations (see Almazán-Holguín and Trelles-Monge, 1986). The main minerals include subhedral phenocryst of alkali feldspars, quartz (corroded) and plagioclase (with disequilibrium texture) ranging in size from 300 to 500 microns. Biotite is a minor mineral. Accessory minerals include zircon and $\mathrm{Fe}-$ Ti oxides, with quartz veinlets and devitrification spherules as secondary minerals.

Petrographic (Figure 7) and field observations (Figure 4) indicate this silicic volcanic unit to be a moderately fractured, light-pink to very light-brown, welded porphyritic rhyolitic ignimbrite that lacks both strongly welded volcanic

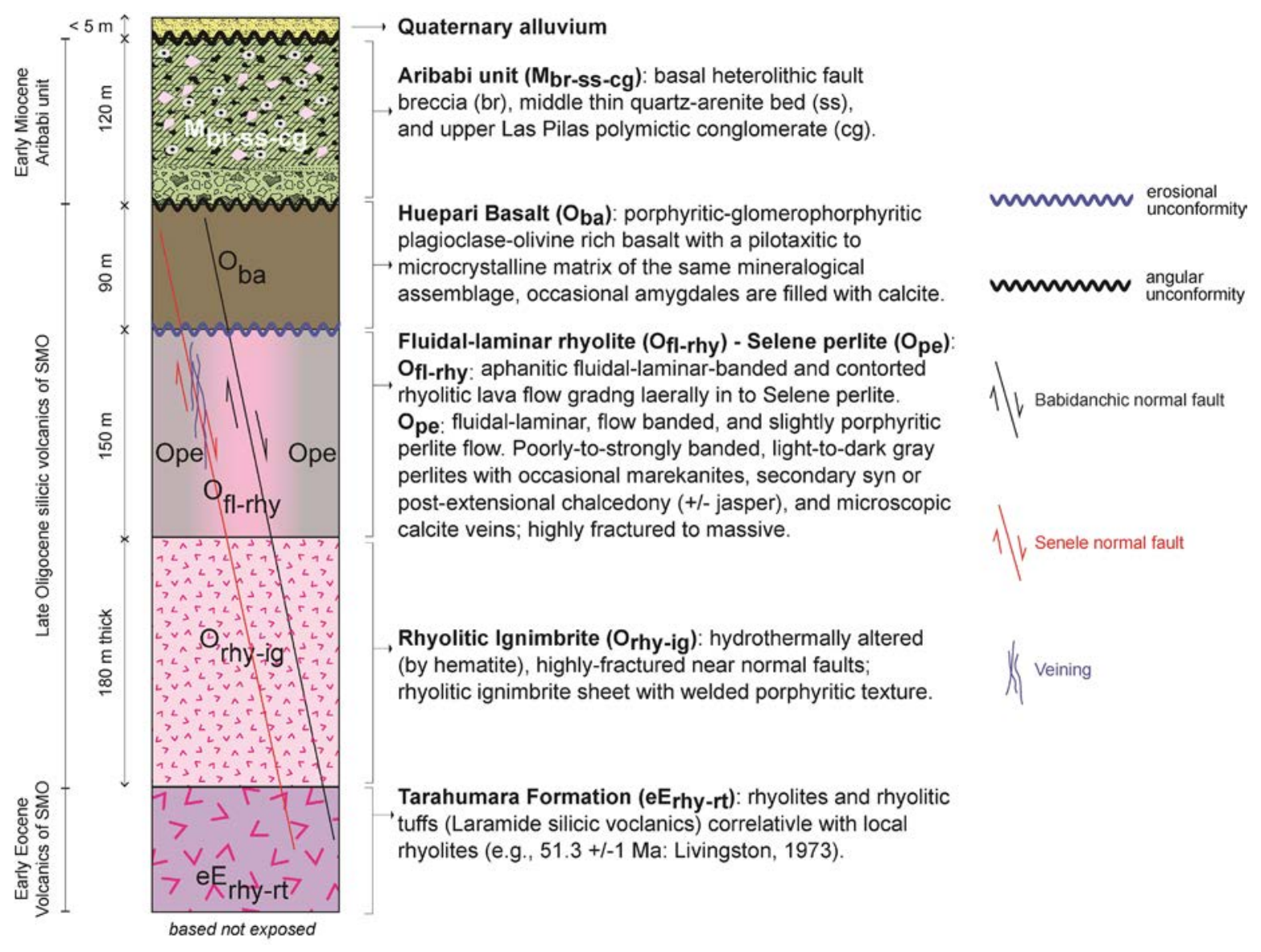

Figure 6. Lithostratigraphic column of the Selene perlite prospect, northeastern Sonora, Mexico. 


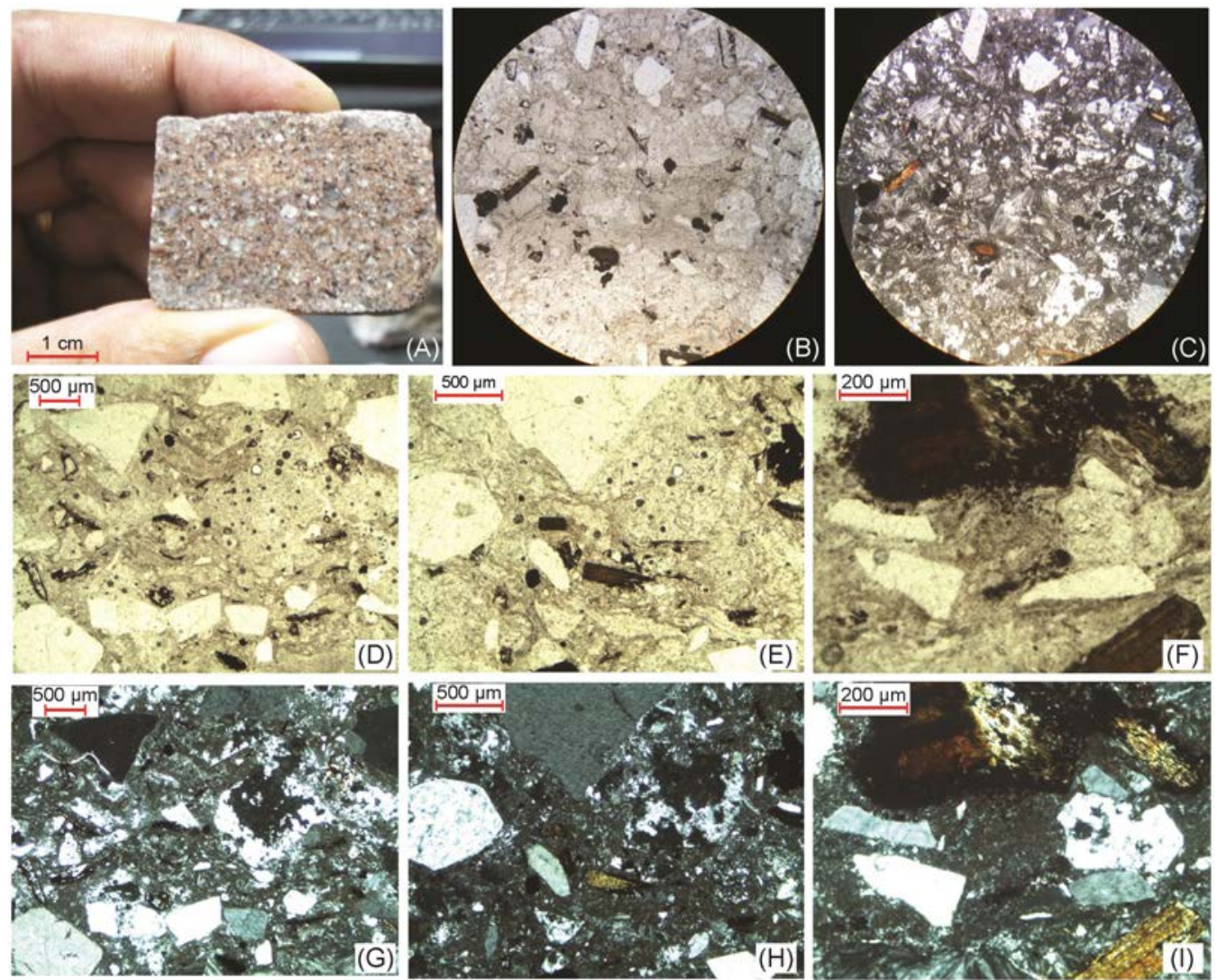

Figure 7. Petrography of the Babidanchic rhyolitic ignimbrite. Rock slice with a high concentration of crystals and lithic fragments in a devitrified glass matrix (A). Photomicrograph taken with a $2.5 \times$ total power and natural light showing the phenocrysts of quartz, feldspar, plagioclase, biotite and Fe-Ti oxides (B). Same view as B in crossed nicols (C). Phenocrysts of alkali feldspar, plagioclase, quartz, and biotite in a vitric matrix; natural light (D). Pumice fiammes in a eutaxitic matrix; natural light (E). Feldspar fragment with sieve texture and biotite micro-phenocrysts (F). (G), (H) and (I) have the same view as D, E and F, respectively, but with crossed nicols.

facies and rheomorphic textures. The Babidanchic rhyolitic ignimbrite is overlain by a flow-banded rhyolitic lava flow, the Selene perlite flow, and the Huepari basalt (Figures 4 and 5 B-C). The nature of the contact between them shows that the Babidanchic rhyolitic ignimbrite was differentially eroded (SPP, 1987) prior to the eruption of the overlying flow-banded rhyolitic lava flow. Prior to the present study, this silicic volcanic unit was mapped as a moderately fractured, differentially eroded, rhyolitic volcanic breccia with a glassy matrix that was of pyroclastic origin and correlative with nearby Tertiary volcanic rocks (SPP, 1987). Palafox-Reyes et al. (1998) mapped the unit as part of the Oligocene rhyolitic lavas and ignimbrites at the southern tip of the SET (Figure 2).

The Babidanchic rhyolitic ignimbrite is here considered to be a rapidly cooled ignimbrite sheet. The volcanic facies is interpreted as proximal-distal of a silicic explosive eruption likely from nearby vents or caldera(s) controlled by pre-existing normal faults and associated fractures/ fissures. Field evidence for such a vent system is suggested by resistant, vertical silicic intrusions that can be seen from the southern edge of the Sierra El Chapulín (Figures 3 B-C). These intrusions occur $\sim 12 \mathrm{~km}$ southwest of the
Selene perlite prospect, have a rhyolitic composition, and lie within the NS-trending normal fault zone west of the Sierra El Chapulín (Figures 2 and 3 B-C). They have been assigned an Oligocene age (Palafox-Reyes et al., 1998) and correspond to vent-proximal facies deposits.

Flow-banded rhyolitic lava flow: This silicic volcanic unit is pink to very light brown with an aphanitic, flowbanded, perlitic base and contorted texture at both the macro and microscopic scale (Figure 8). It strikes NW, dips $25-35^{\circ}$ ENE, and only crops out along a steep, NW-SEtrending $\sim 1100 \mathrm{~m}$ - long scarp (Figures 4 and $5 \mathrm{~A}$ ), where it is sandwiched between the basal Babidanchic rhyolitic ignimbrite and the upper Huepari basalt. To the NW and SE, the flow-banded rhyolite unit grades laterally into the Selene perlite ore bodies $I$ and VI, respectively (Figure $5 \mathrm{~A}$ ), an observation also reached by Almazán-Holguín and TrellesMonge (1986). Fractures and flow banding occur in the margins of the rhyolitic lava and near the gradational contact with the Selene perlite flow (Figure 4). The compositional bands comprise alternations of quartz-feldspathic material and glass with concentrations of quartz and chalcedony (see Almazán-Holguín and Trelles-Monge, 1986). Dykes, sills, hypabyssal intrusions, and/or signs of hydrothermal 
alteration were not observed. Petrographic examination indicates an aphanitic, flow-banded, and contorted rhyolitic lava with a microcrystalline matrix composed of quartz, alkali feldspar and late micro-phenocrysts of biotite (Figures $8 \mathrm{~A}-\mathrm{H})$. Zircon crystals ( $<5$ microns) and Fe-Ti oxides are accessory minerals, with quartz veinlets as a secondary mineral.

Almazán-Holguín and Trelles-Monge (1986) assigned a Middle Eocene-Early Oligocene age to this rhyolitic unit in relation to middle Tertiary arc volcanism. PalafoxReyes et al. (1998), however, assigned a Late Oligocene age, which is supported by our lithologic correlations with the nearby El Globo Rhyolite ( $24 \pm 0.4 \mathrm{Ma}$, K/Ar age on biotite; Livingston, 1973) (see section 6) that forms part of the SMO silicic volcanics of northeastern Sonora. A Late Oligocene emplacement age would imply that the flow-banded rhyolitic lava in the Selene perlite prospect corresponds to the Upper Volcanic Supergroup (e.g., McDowell and Keizer, 1977).

The flow-banded rhyolitic lava is interpreted to be the near-vent lava dome-flow facies deposit of an intracaldera effusive volcanic complex; however, continuing extensional crustal deformation and erosion across the region has eroded the intracaldera structure.

Selene perlite flow: Our mapping revealed four new, well-exposed perlite occurrences labeled $I I I, I V, V$, and $V I$ located next to the previously documented perlite bodies $I$ and II (Figures 4 and 5A). At a regional scale, both SPP (1987) and Palafox-Reyes et al. (1998) assigned a Late Oligocene age to the rocks hosting the Selene perlite. This implies that the Selene perlite ore body also belongs to the Upper Volcanic Supergroup (e.g., McDowell and Keizer, 1977). The morphology of the $3 \times 2.5 \mathrm{~km}$ hill hosting the Selene deposit resembles a dome-flow structure of small dimensions. The thickness of the Selene perlite flow is estimated to be $\sim 150 \mathrm{~m}$ (Figure 4). Perlite ore bodies $I, I I$, and $I V$ are cut by a normal fault. In general, these rocks are aphanitic, light-to dark-gray perlites with a vitreous flowbanded texture (Figure 9). Perlite rocks strike NW-SE and dip -NE at $\sim 30^{\circ}$ (Figure 4 ). Flow banding is prominent in the central and northern parts of the ore body I (i.e., NE and NW lobes) (Figures 5A and 9 A-C). Flow banding varies from planar parallel to wavy non-parallel and is very closely spaced (1 to $50 \mathrm{~mm}$ thick). It is composed of alternating bands of obsidian and light-to dark-gray perlite and contains ubiquitous, thin (mm thick) joints and randomly oriented cracks. Flow banding strikes mainly NW-SE and dips 20 $-45^{\circ}$ ENE (Figure 9C). Flow folding is clearly evident in the perlitic bodies $I$ (Figure 9E) and VI, and in the margins of the rhyolites (Figures 5D and 9A), roughly along the same elevation line. These zones of flow folding are in close proximity to each other.

Well-rounded, black marekanite (obsidian nodules, 2 - 5 $\mathrm{cm}$ in diameter) locally define a typical "bull's eye" texture (Figs, 9 A-C); however, small, but occasional thick lenses of red obsidian also exist within the flow banding and as thick lenses (Figures 9 E-F). Marekanites are clearly evident on the central-southern and northwestern margins of perlitic ore bodies $I$ (Figures $10 \mathrm{~A}-\mathrm{D}$ ) and $V$, respectively (i.e., near the outcropping flow-banded rhyolite flow). The marekanites float in massive (Figure 10A) and strongly flow-banded and flow-folded perlitic rocks (Figures $10 \mathrm{~B}-\mathrm{C}$ ). The presence of marekanite and/or thin bands of obsidian is an indicator of underhydrated zones relative to the perlite that wraps around the marekanite and/or the obsidian layers.

A NE-trending extensional fault cuts the NW lobe (Figure 4), and a network of cm-thick white chalcedony (primary) and jasper (secondary) veins occur near the fault plane (see section 5.2). Petrographic observation of this lobe reveals a vitreous fluidal lava with well-developed perlitic and weakly developed porphyritic textures, the latter defined by poorly developed crypto-phenocrysts of alkali feldspar, quartz, biotite, and clinopyroxene aligned with the direction of flow (Figures 11 A-I). Secondary minerals include quartz and calcite veinlets filling tensional fractures (Figures $11 \mathrm{~J}-\mathrm{K})$. Accessory minerals include apatite and very small ( $<5$ microns) zircon crystals. Two generations of perlitic texture are observed in thin section (Figures 11 F-I). The first is characterized by small concentric fractures that define thin gray bands of perlite that are occasionally sandwiched by laminations of black obsidian. The second is defined by much larger concentric fractures that wrap around those of the first generation. Both generations of fractures are cut by microfaults and microcracks occasionally filled by quartz and/or calcite (Figure 11K). The microfaults show normal slip that displaces the perlitic texture as well as the thin bands of obsidian (Figures 11 L-P). Our petrographic examinations match those of Almazán-Holguín and TrellesMonge (1986).

Cooling joints are abundant in the Selene perlite flow (Figure 12 A-D), and occasionally present in the flow-banded rhyolites and rhyolitic ignimbrites, but are not observed in the Huepari basalt. We focus on jointing in the Selene perlite flow where the spacing of the joints varies greatly. They are very closely spaced (30 to $50 \mathrm{~mm}$ ) in the central part of the perlite body I (Figures $12 \mathrm{~A}-\mathrm{C}$ ), but at another outcrop in the NW lobe, numerous widely spaced ( $800 \mathrm{~mm}$ ) parallel joints trend NE-SW and dip SE at moderate angles. Very widely spaced ( $>2 \mathrm{~m}$ ) joints also occur at the edges of the NW and NE lobes (Figures $12 \mathrm{~A}-\mathrm{B}$ ). These joints trend eastwest, are vertical to subvertical (Figure 12D), and have an orthogonal relationship with respect to layering. The cooling surface(s) controlled the orientation of the cooling joints. The middle and southernmost parts of the Selene perlite flow (i.e., bodies $I, V$ and $I V$ in Figures 4 and 5A) overlie the Babidanchic rhyolitic ignimbrite sheet, while its northern, western, and eastern margins underlie the Huepari basalt (Figures 4 and 5 B-C). Perlitic ore bodies $I$ and VI grade laterally in to the flow-banded rhyolitic lava flow (Figure $5)$. This gradation is relatively flat lying, follows a roughly constant elevation line ( 1500 masl), and is seen in the west-central zone of the Selene perlite prospect (Figures 4 

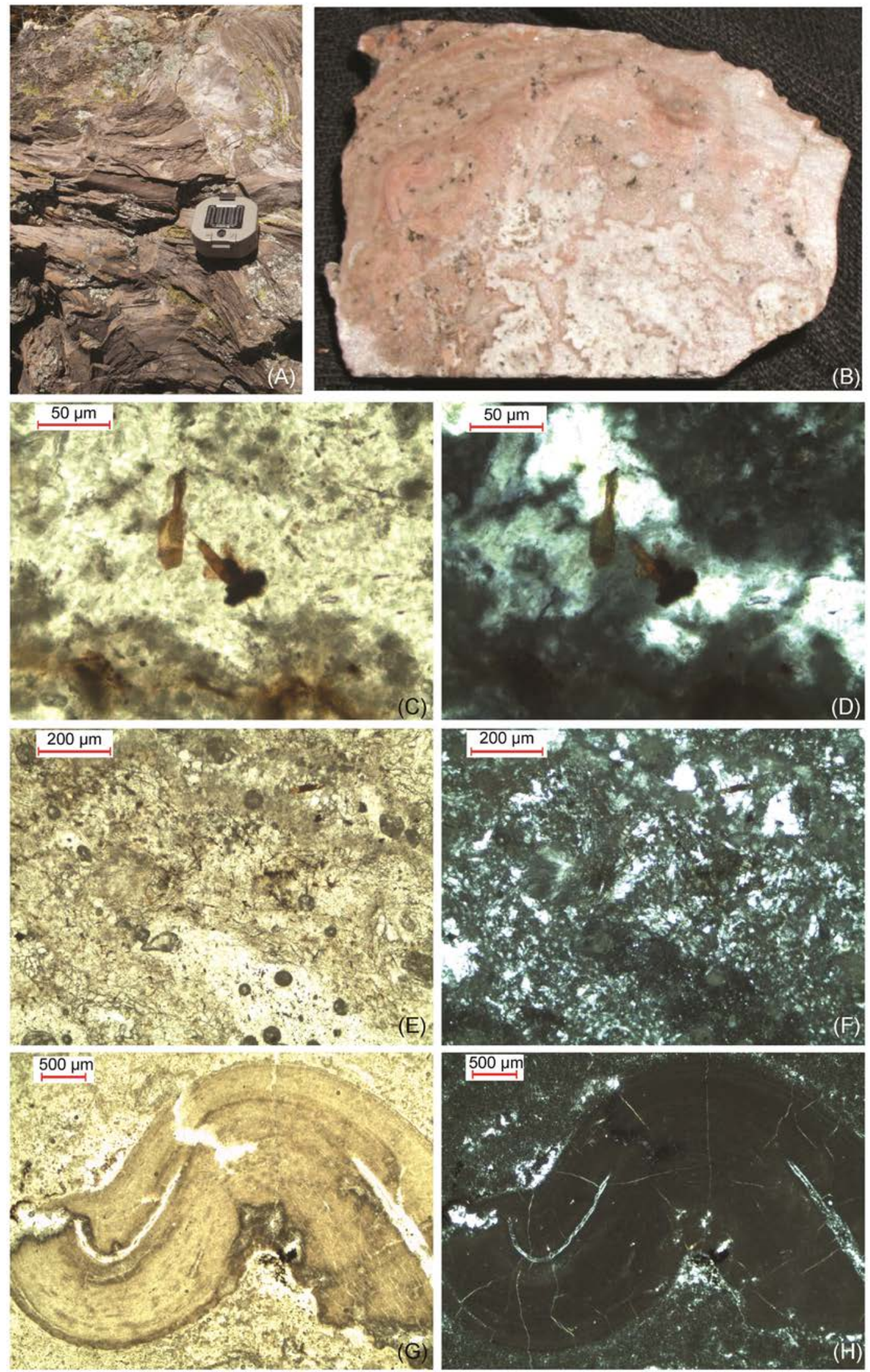

Figure 8. Field photograph of outcrop (A), $3 \times 5 \mathrm{~cm}$ hand sample (B) and petrographic photographs of the flow-banded rhyolitic lava flow (C-H). Microcrystalline matrix interlayered with a contorted flow banded obsidian $(\mathrm{G}$ and $\mathrm{H})$. Thin sections showing porphyritic texture comprising fine, sparse, euhedral phenocrysts of feldspar, quarts and biotite in a microcrystalline groundmass of the same mineral composition (C, E, G polarized light and D, F, H crossed nicols). 

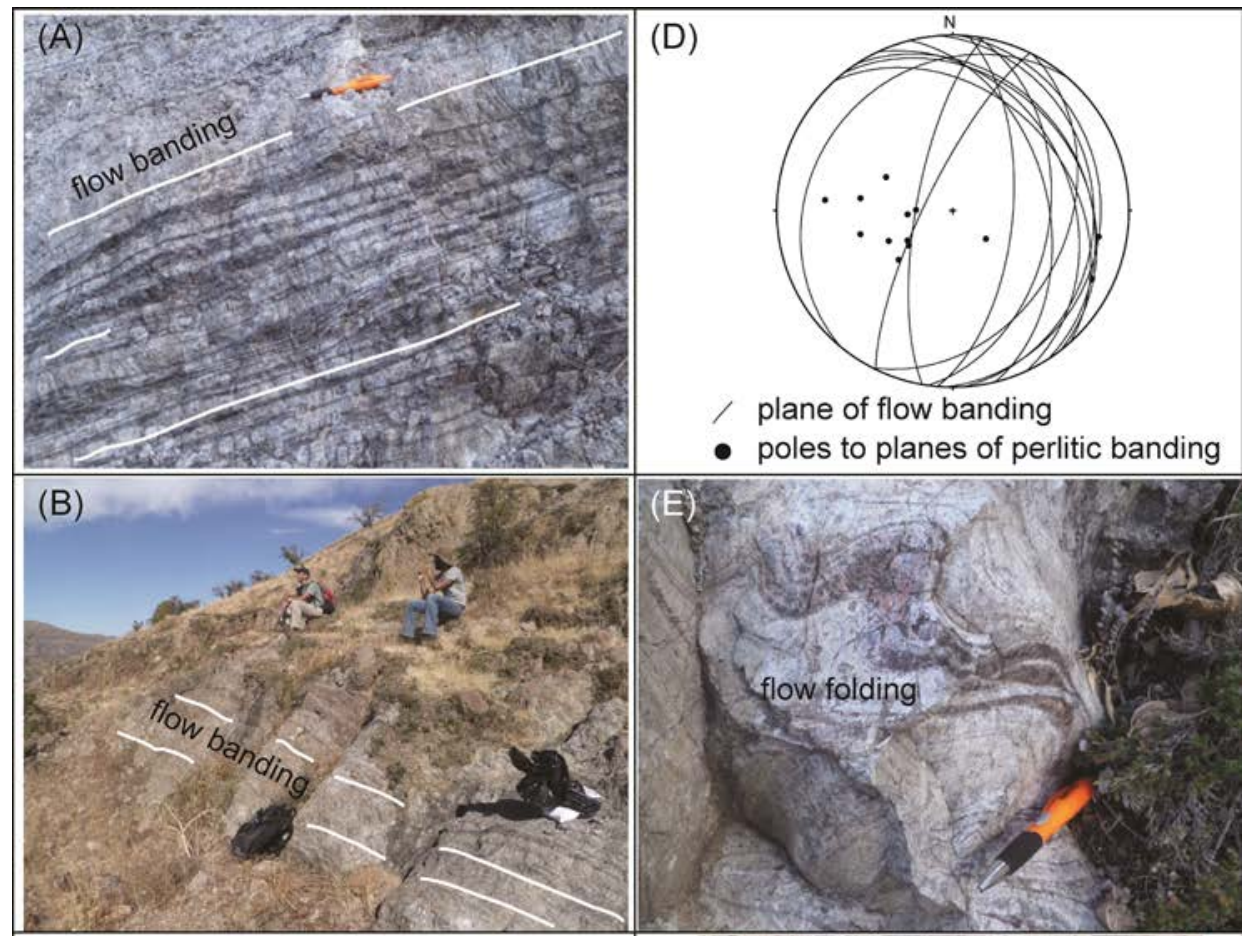

(C)

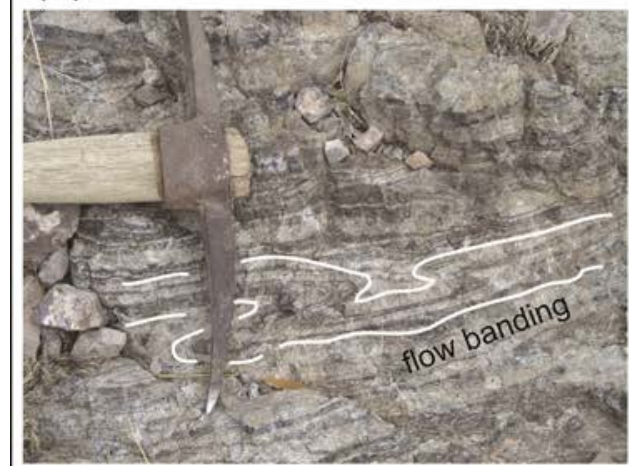

(F)

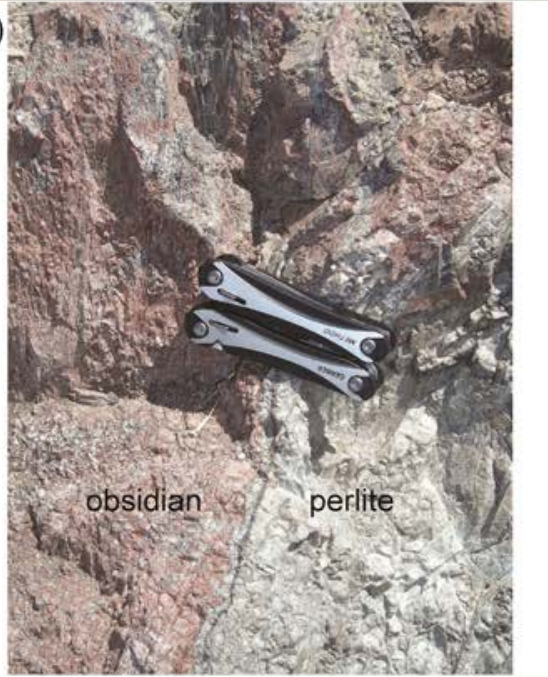

Figure 9. Representative filed photographs of perlitic banding (A-C), structural data of perlitic banding plotted in stereonet of equal-area lower-hemisphere projection (D), and perlitic flow-folding (E). Perlitic banding dips gently- to- moderately toward the east (D). Perlitic banding and perlitic flow-folding are defined by intercalations of perlite and black- or- red obsidian. Thick band of red obsidian in perlite (F).

and 5A). This is the only area where we observe the Selene perlite flow grading into the flow-banded rhyolite lava flow (see Almazán-Holguín and Trelles-Monge, 1986).

Several petrologic features indicate that the Selene perlite flow corresponds to extensively hydrated margins of the flow-banded rhyolitic lava dome. These features include: (i) flow banding in the perlitic rocks and in the margins of the flow-banded rhyolitic lava flow; (ii) the proximity of the marekanite outcrops relative to the margins of the flowbanded rhyolitic lava flow, which represents nonhydrated (dry) rock mass; (iii) the gradational contact between the perlites (e.g., bodies $I, V I$, and $V$ ) and the flow-banded rhyolitic lava flow; and (iv) the remarkably similar structural attitudes of the flow-banded rhyolitic lava and Selene perlite flows (i.e., $\sim 30^{\circ}$ dip towards the ENE). Therefore, the Late Oligocene flow-banded rhyolitic lava flow is interpreted to be the parent rock of the Selene perlite flow. Consequently, the Selene perlite flow shares the same volcanic facies of its host rocks, (i.e., a near-vent lava dome-flow facies deposit). This implies that the Selene perlite flow probably has a nonhydrated core of as yet unknown geometry, and that the gradational contact with the flow-banded rhyolitic lava flow most likely continues into the subsurface. The absence of exploratory drills and/or geophysical data hampers the 

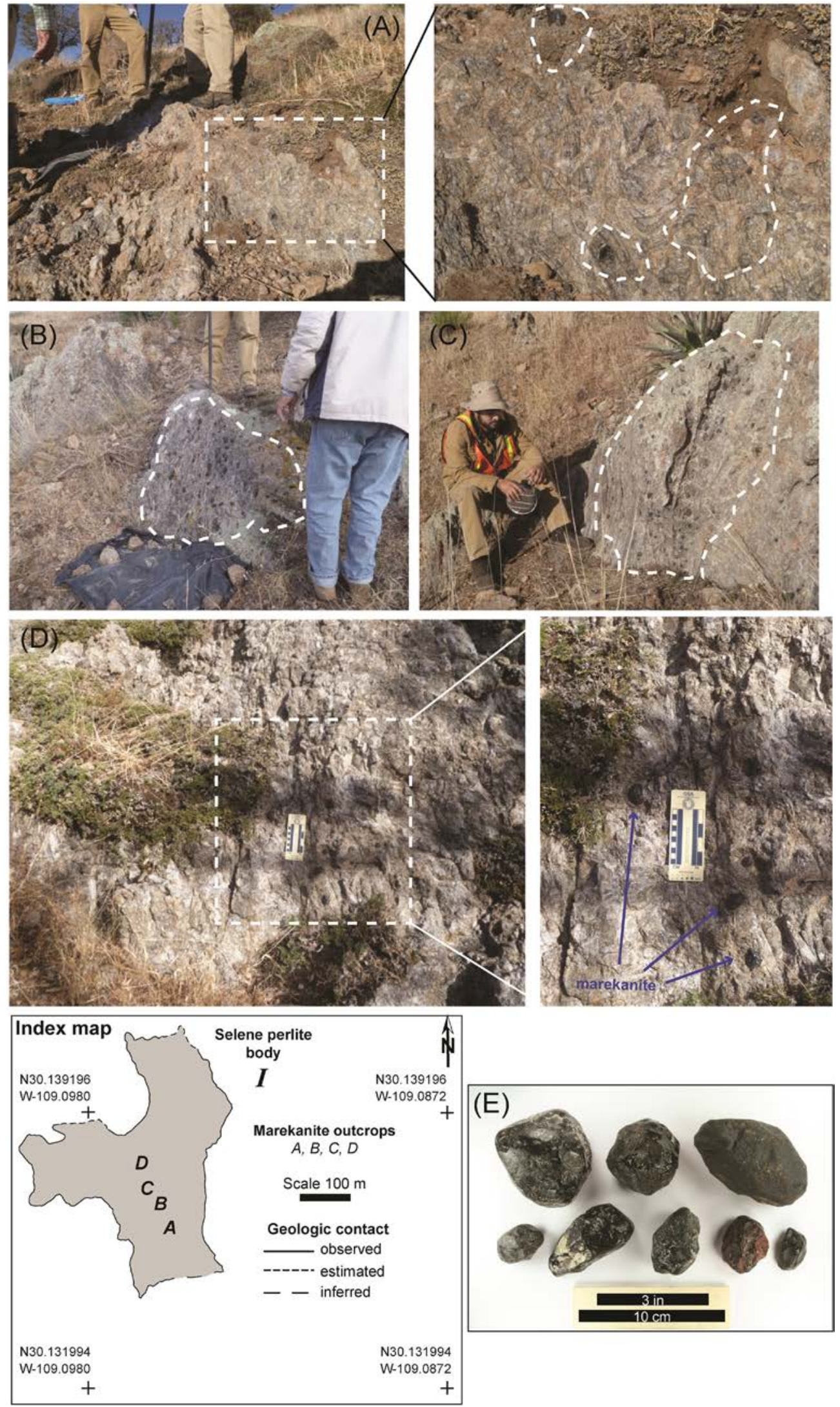

Figure 10. Representative field photographs of marekanite outcrops (A-D) within perlite ore body $I$ and extracted marekanite samples (E) to highlight color, size, and shape. Outcrop A is characterized by marekanites floating in a mildly perlitic texture (A) dominated by contorted bands of fine-grained rhyolitic composition that indicates less hydration compared to adjacent outcrops B, C, and D which show marekanites embedded in a well-defined perlitic texture in turn suggesting more hydration. 
underground characterization of the perlite flow and a precise quantification of perlite reserves.

Huepari basalt: This mafic unit overlies the Selene perlite flow, the flow-banded rhyolite lava flow, and the Babidanchic rhyolitic ignimbrite along an erosional unconformity (Figures 4, 5 B-C, and 6). This stratigraphic evolution - from silicic to mafic volcanics - is typical of the northern SMO silicic large igneous province (Cameron et al., 1989; Ferrari et al., 2007). The Huepari basalt is defined as a reddish-brown to dark-brown or dark-gray, medium- to coarse-grained plagioclase-pyroxene-olivine basaltic lava flow. The Huepari basalt is faulted and uplifted, and eroded cobbles and boulders dot the valley between the perlite prospect and Aribabi village. The basalt is also
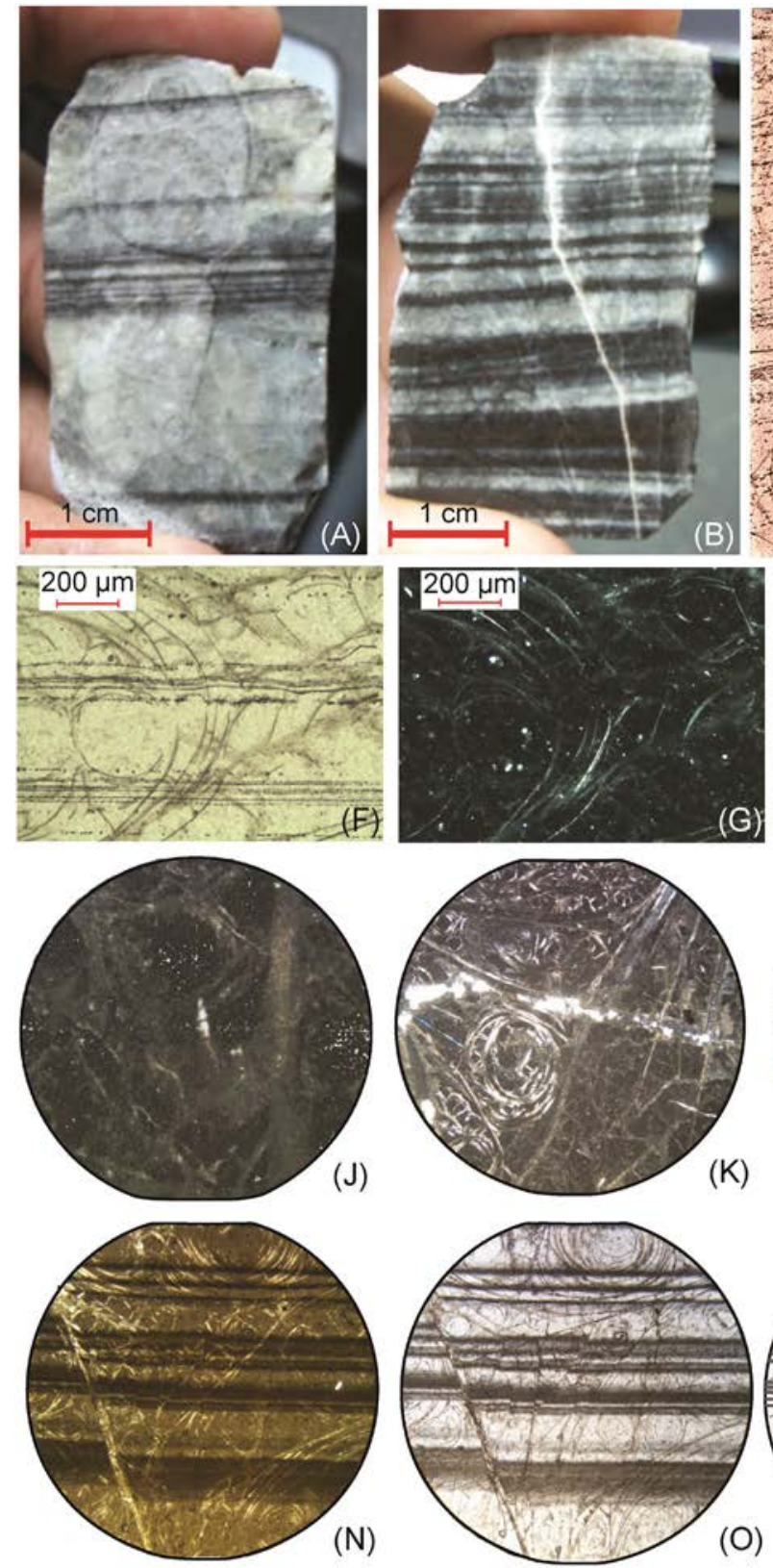
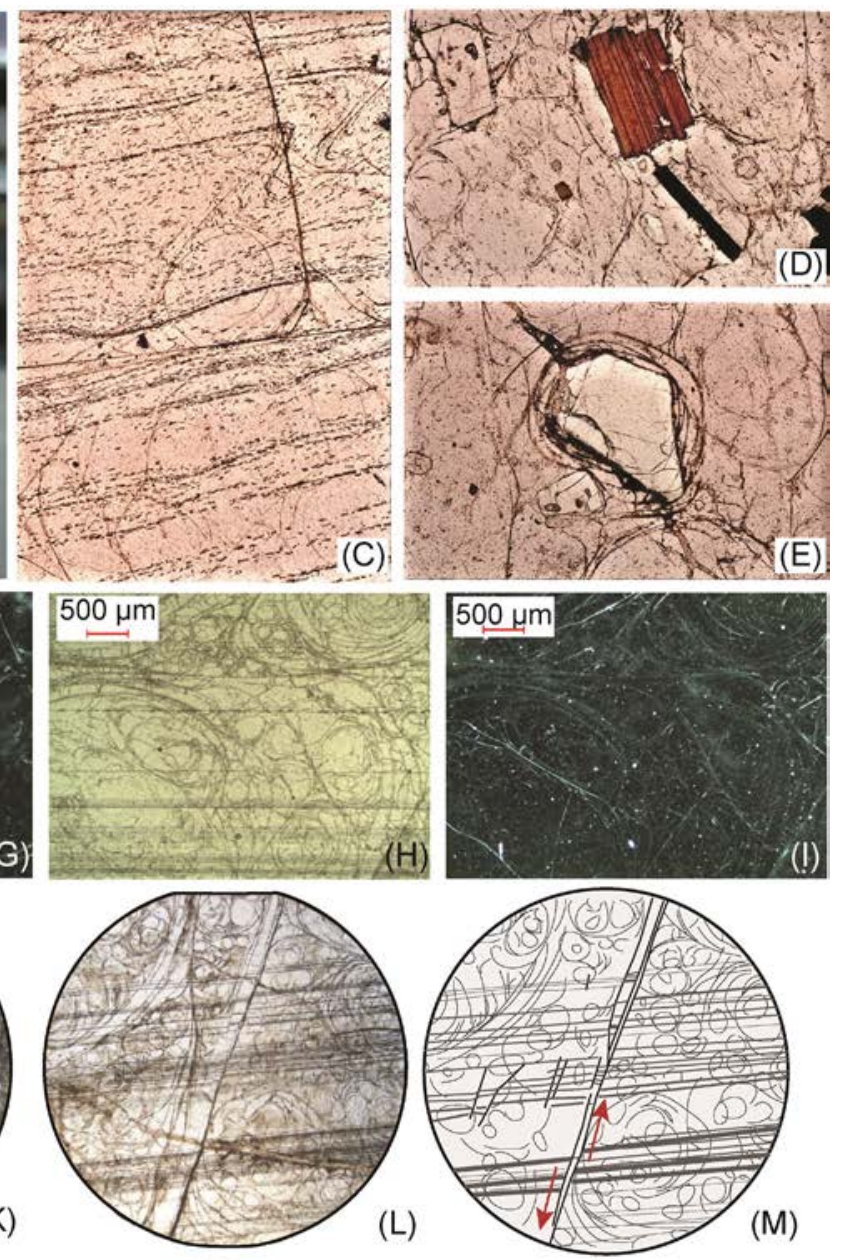

(M)

Figure 11. Thin sliver cut from a hand sample of the Selene perlite showing two types of obsidian banding flow (A and B). Poorly developed perlitic fracture in a contorted flow texture marked by fluid inclusions (C); plane polarized light and a $5 \times$ objective. Photomicrograph showing a mineralogical association of alkaline feldspar, biotite and quartz in a glassy matrix of incipient perlitic texture (D); plane polarized light and a $5 \times$ objective. Fractured quartz phenocryst as a core of the perlitic fracture development, $5 \times$ objective, natural light $(\mathrm{E})$. Thin-sections show that the perlitic glass contains abundant microphenocrysts and bands that are defined by varying concentrations of aligned microlites; polarized light (F, H) and crossed nicols (G, I). Perlitic fractures filled by secondary minerals ( $\mathrm{J}, \mathrm{K}$ and $\mathrm{N}$ and a $10 \times, 2.5 \times$ and $2.5 \times$ objective, respectively); crossed nicols. Normal micro-faults in Selene perlite (L); plane polarized light, $2.5 \times$ objective. Structural interpretation of L (M). Same view as N in natural light (O) and a $2.5 \times$ objective. Structural interpretation of $\mathrm{O}(\mathrm{P})$. 


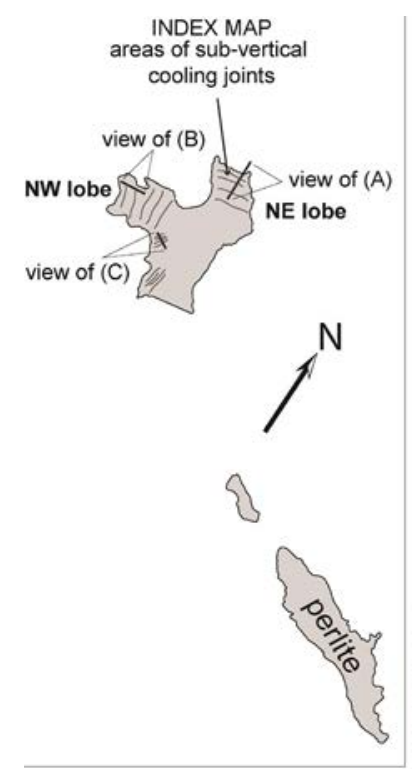

(B) NW-SE profile of NW lobe

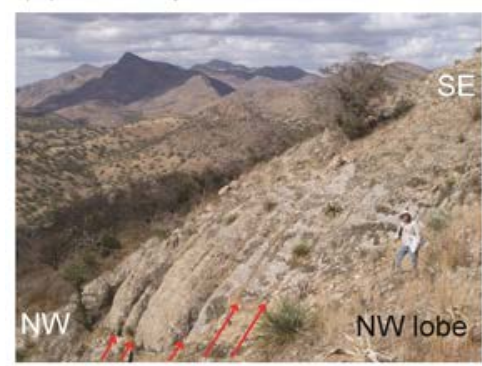

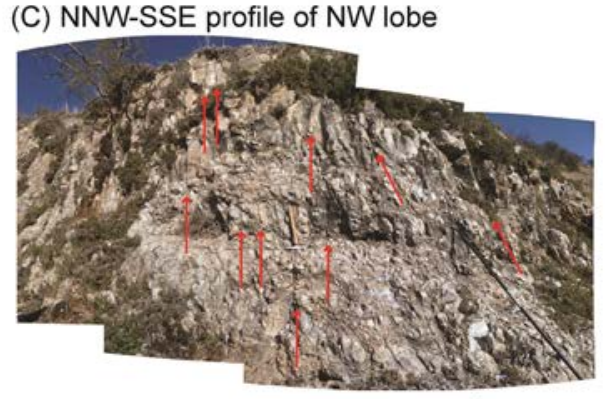

vertical-to-subvertical joints $=\uparrow$
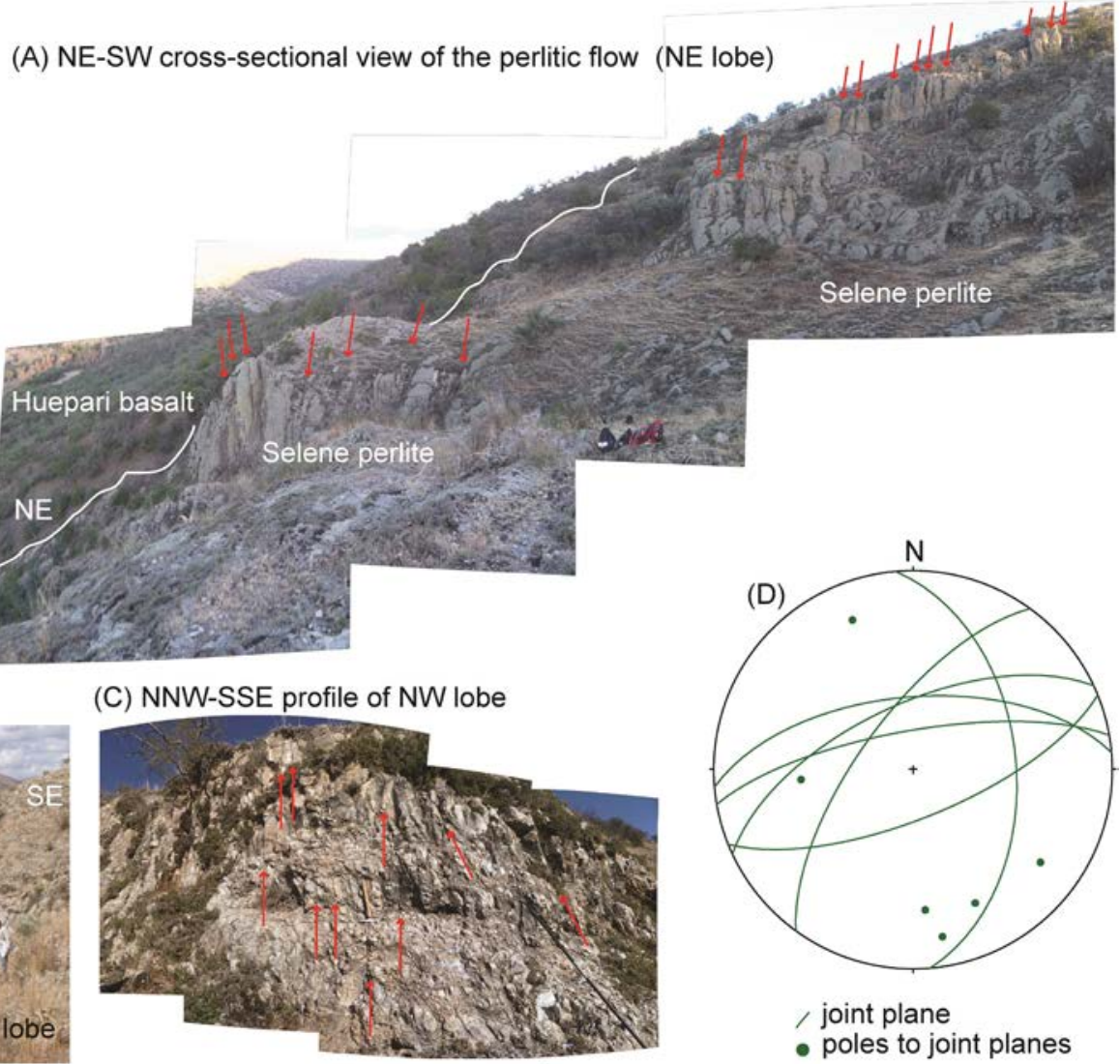

Figure 12. Representative field photographs of vertical to sub-vertical cooling joints in perlite ore body $I$ with very-wide ( $>2 \mathrm{~m})$ (A, backpacks in the middle of the photo for scale) to extremely- close $(<20 \mathrm{~mm})(\mathrm{C}, 2 \mathrm{~m}$ - long iron bar in the lower right-corner of the photo for scale) joint spacing. Stereonet of equal-area lower-hemisphere projection of joint planes trending EW and NS, dipping steeply towards the N, S, E, and W. Inset map depicts perlite ore bodies $I, V$, and $V I$.

well-exposed between the perlite prospect and the village in the form of horizontal to gently ENE-dipping $\left(25^{\circ}\right)$ lava flows that dominate the landscape south and east of the prospect (SPP, 1987; Palafox-Reyes et al., 1998). Deposition of coarse- to very coarse-grained basaltic clasts occurs in the perennial streams. The basalt also strongly supports the growth of vegetation when compared to the underlying silicic volcanics, and creates the jagged topography south and east of the prospect (Figures $6 \mathrm{~A}-\mathrm{C}$ ). The basaltic lavas around the Selene perlite prospect have been variously assigned a Quaternary emplacement age (SPP, 1987), a Late Oligocene-Early Miocene age (Almazán-Holguín and Trelles-Monge, 1986), and a Late Oligocene age (PalafoxReyes et al., 1998). The Late Oligocene age is currently the widely accepted age for these basaltic lavas.

The Huepari basalt within the mapped area is strongly amygdaloidal at the top and porphyritic at the base; however, amygdules $(1-4 \mathrm{~mm})$ occur locally throughout (Figure 13A). The flow is best exposed in a $\sim 77 \mathrm{~m}$ - thick package immediately west of the perlite ore body I (Figure 4). Here, reddish-brown and white calcite (along with zeolite and apophyllite) fills the amygdules, typical of hydrothermal activity or vapor phase alteration (AlmazánHolguín and Trelles-Monge, 1986). The porphyritic basalt exists at higher stratigraphic levels as an unweathered to weathered, NW-striking, ENE-dipping $\left(25^{\circ}\right), 3-13 \mathrm{~m}$ thick lava flow (Figures 4, 5 B-C). It is dark-gray on a fresh surface and contains oxidized olivine crystals, $1-3 \mathrm{~mm}$ in diameter (Figure 13B), with occasional mm-scale fractures. Amygdules are uncommon and lack secondary mineral fillings (i.e., calcite), suggesting that fluids may have not reached higher stratigraphic levels within the flow or that the amygdaloidal horizon existed but has been eroded, likely due to uplift related to the normal faulting. Petrographic analyses (Almazán-Holguín and Trelles-Monge, 1986; this study) reveal a porphyritic-glomeroporphyritic texture with plagioclase, clinopyroxene, orthopyroxene and olivine as the main phenocryst phases in a pilotaxitic to microcrystalline matrix of the same mineralogical assemblage (Figures 13 $\mathrm{C}-\mathrm{H}$ ). Fe-Ti oxides and calcite-filled amygdules constitute the accessory and secondary minerals, respectively. The olivine crystals are oxidized as seen in thin section (Figures 

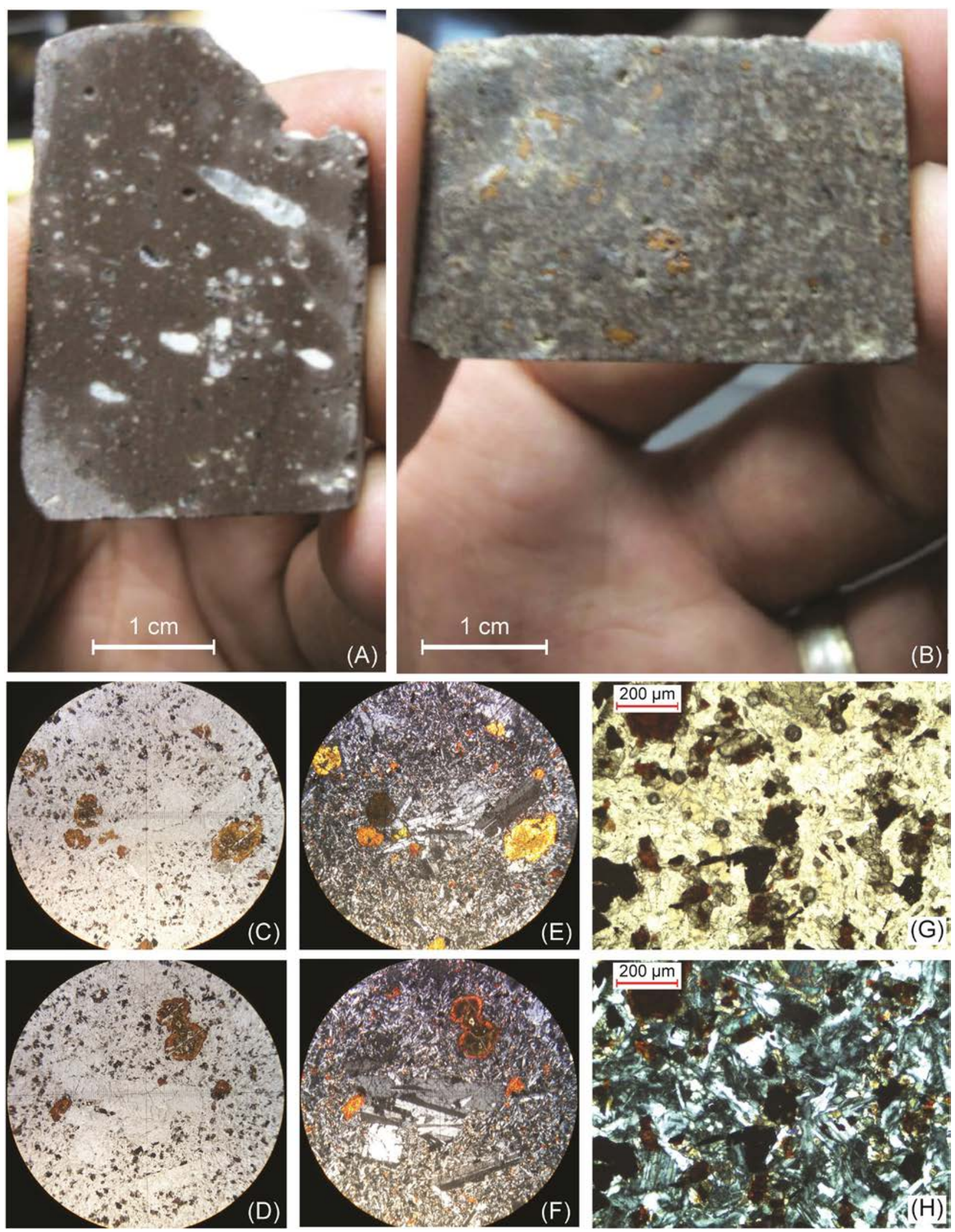

Figure 13. Thin slivers cut from a hand sample of the Huepari basalt and petrographic photographs. Slices show lenticular calcite-filled amygdules (A) and a porphyritic texture comprising plagioclase and oxidized olivine phenocrysts (B). Glomeroporphyritic texture with iddingsite olivine and plagioclase phenocrysts (C-F); $2.5 \times$ objective, plane polarized light and crossed nicols. Intergranular micro-crystalline matrix composed of plagioclase, olivine, clinopyroxene and Fe-Ti oxides; plane polarized light $(\mathrm{G})$ and crossed nicols $(\mathrm{H})$. 
13 B-H) and in outcrop.

The western edge of the Huepari basalt is cut by both the newly found Babidanchic and Selene faults (Figure 4). The faults and associated fractures/fissures likely functioned as a vertical-subvertical conduit for the rising mafic magma. This eruption pattern is common throughout the Nacozari Mining District (SPP, 1987; Palafox-Reyes et al., 1998), and has been well-documented and dated in the northern (Ferrari et al., 2007; Murray et al., 2013, 2014; Murray and Busby, 2015) and southern SMO (Aguirre-Díaz and McDowell, 1993). No cross-cutting dikes, sills, and/ or hypabyssal intrusions were observed in the Huepari basalt. The higher stratigraphic position and assigned Late Oligocene emplacement age also imply that the Huepari basalt most likely belongs to the Early Oligocene to Early Miocene Southern Cordillera basaltic andesite province (SCORBA) of Cameron et al. (1989), which erupted intermittently across the northern SMO silicic large igneous province (McDowell and Keizer, 1977; Cameron et al., 1989; Demant et al., 1989; Ferrari et al., 2007). The mafic rocks of the SCORBA province represent magmatism linked to the onset of crustal extension across the region (Cameron et al., 1989; McDowell et al., 1997; González-León et al., 2000; Ferrari et al., 2007).

We interpret the Huepari basalt as a proximal lava flow facies deposit from a normal-fault-controlled fissurevent system within an intracaldera-graben volcanic complex; however, the continuing extensional deformation widespread across Sonora has eroded the caldera structure.

\subsubsection{Volcaniclastic Aribabi unit}

The volcaniclastic Aribabi unit was deposited in a small $(3.5 \times 8 \mathrm{~km})$, NNW-SSE-trending valley drained by tributary streams that join the Babidanchic River (Figure 4). From now on we informally refer to this valley as the Aribabi valley (after the Aribabi village) (Figures 2 and 3 A-B). The Aribabi unit is well-exposed along the gravelly braided Aribabi and Babidanchic streams, between the Las Pilas Ranch and the Selene perlite prospect. Older geologic maps have referred to the rocks in the Aribabi valley as Quaternary alluvium and basaltic lavas (SPP, 1987) and as Oligocene basaltic lavas covered by Quaternary alluvium (Palafox-Reyes et al., 1998). A detail mapping and stratigraphic analysis of the Aribabi unit was beyond the scope of this study because it occurs outside the limits of the Selene perlite prospect (Figures 3 A-B); however, a noticeable clast population of perlitic pebbles and cobbles (likely from the adjacent Selene perlite flow) was found in the Las Pilas polymictic conglomerate during our mapping season implying a petrologic link to the immediate Selene perlite flow. Yet, the abundance of perlite clasts is of low economic proportions. Therefore, a preliminary description of the Aribabi unit is necessary; consequently, only the northwestern portion of the Aribabi valley was mapped.

The Aribabi unit is bounded to the west by the silicic to mafic volcanic rocks of the Sierra El Chapulín. To the east, it is juxtaposed against the Late Oligocene bimodal volcanic units of the Selene perlite prospect along the $\sim$ NS-trending Babidanchic fault (Figures $3 \mathrm{~A}-\mathrm{B}$, 4). Our geologic mapping shows that, at least near the Selene perlite prospect, the Aribabi unit does not comprise Quaternary alluvium and/ or Oligocene basaltic lavas; instead this volcaniclastic unit records continental clastic deposition of detritus probably derived from the uplifted and partly eroded silicic to mafic volcanic units of the adjacent Sierra El Chapulín and the Selene perlite prospect. The Aribabi unit is not faulted, overlies both the Babidanchic rhyolitic ignimbrite and the Huepari basalt in angular unconformity (Figure 6), and is comprised by three members: the basal fault breccia, the previously unrecognized middle thin quartz-arenite bed, and the upper Las Pilas polymictic conglomerate, all shown in Figure 14. Dykes, sills, and/or hypabyssal intrusions were not observed in any of the sedimentary members. Based on the aforementioned structural and stratigraphic relationships and the volcaniclastic material contained in its members, the deposition of the Aribabi unit is inferred to be no older than Early Miocene (Figure 6).

Fault breccia: The fault breccia crops out in the Babidanchic stream immediately northwest of the Selene perlite ore body $I$ next to the Babidanchic normal fault (Figures 4 and $14 \mathrm{C}-\mathrm{D}$ ). The fault breccia occurs in the hanging wall of the Babidanchic normal fault (Figures 5 and 14). Outcrop observations indicate that this clastic member is a non-foliated heterolithic, very poorly sorted, angular to very angular, clast-supported, chaotic fault breccia with a fine-grained matrix, following the definition of Woodcock and Mort (2008). Both the sorting of the clast and the bedding are very poor. The grain size ranges from pebbles to boulders; however cobbles and boulders dominate the clast population ( $60 \%$ ) characterized by randomly oriented fragments of rhyolitic ignimbrite, basaltic lavas, and lesser andesitic lavas (Figures $14 \mathrm{C}$-D). The composition of fragments in the fault breccia is similar to that of the silicic and mafic lavas within the Selene perlite prospect, suggesting local provenance of transported eruptive products. No perlite clasts were observed in the fault breccia. The fault breccia overlies the Late Oligocene Huepari basalt and the Babidanchic rhyolitic ignimbrite in a moderate angular unconformity (Figure 6).

It is worth mentioning that Almazán-Holguín and Trelles-Monge (1986) have described the fault breccia as a heterolithic agglomerate composed of basaltic, rhyolitic, and pyroclastic clasts up to $50 \mathrm{~cm}$ in size floating in a matrix of calcite and tuffaceous sandy-muddy material deposited in response to the uplift and subsequent erosion of the bimodal volcanic sequence of the Selene perlite prospect. However, these authors did not report the existence of the Babidanchic fault, which runs parallel to the fault breccia (Figures 4 and 14).

Quartz-arenite bed: A $\sim 1 \mathrm{~m}$ - thick quartz-arenite bed occurs as two small patches: one in the hanging wall and another in the footwall of the Babidanchic fault (Figure 4). 


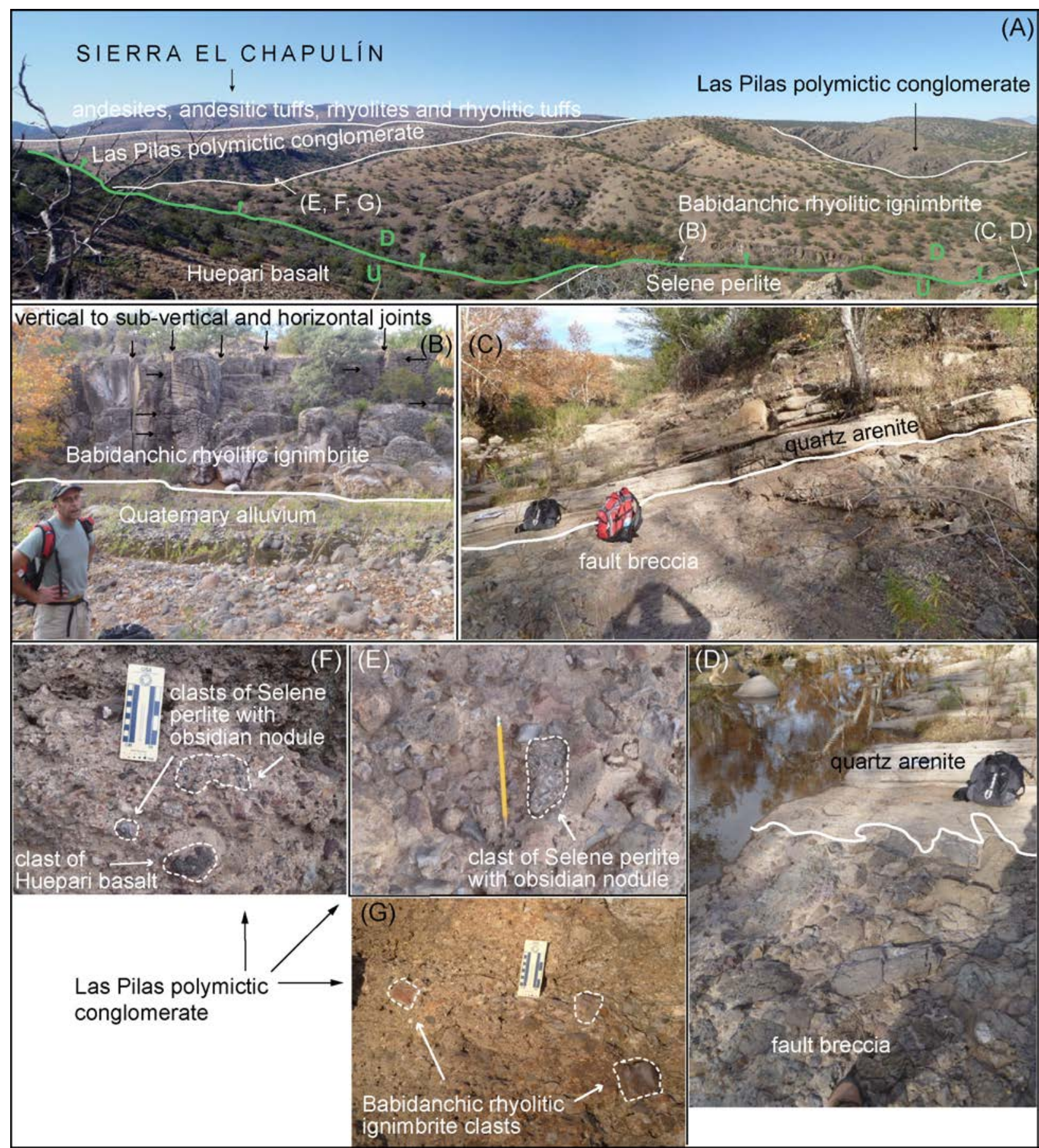

Figure 14. Representative panoramic photograph of the rocks west of the Selene perlite prospect viewing toward the west from the Selene perlite ore body $I$ (A). The trace of the $\sim$ NS-trending, W-dipping Babidanchic normal fault is drawn in (A). Fractured Babidanchic rhyolitic ignimbrite and Quaternary alluvium (B). Volcaniclastic Aribabi unit: basal fault breccia overlain by middle thin quartz-arenite (C-D), and upper Las Pilas polymictic conglomerate containing fragments of perlite, rhyolitic ignimbrites, and basaltic lavas (E-G). U-Upthrow block; D-Downthrow block.

The quartz arenite is defined as a medium to thickly planar bedded, coarse-grained, texturally mature, very light-brown quartz-arenite. Individual beds range from 15 to $40 \mathrm{~cm}$ - thick with sharp, parallel, and planar bed contacts (Figures 14 C-D). The bedding strikes E-W and dips shallowly towards the north $\left(285^{\circ} / 18 \mathrm{~N}\right)$ because it is gently folded into an open fold with a NE-SW-trending fold axis. The stratigraphic contact between the fault breccia and the quartz arenite is a sharp planar EW-striking disconformity. Only the quartz arenite crops out as a small patch, but thickens outside the Babidanchic stream where it overlays the Huepari basalt (off the dirt road) along a nonconformity (Figure 4). This may suggest that deposition may pre-date the Babidanchic normal fault. The quartz arenite is not observed under the 
Las Pilas polymictic conglomerate suggesting that it might be a small lenticular deposit (i.e., channel deposit) that pinches out toward the Las Pilas polymictic conglomerate.

Las Pilas polymictic conglomerate: This $\sim 100 \mathrm{~m}$ - thick clastic member crops out along the Aribabi stream and is well-exposed in front of the Las Pilas Ranch (Figure 4). The grain-size ranges from very-coarse sand to boulder $(5-300 \mathrm{~mm})$. The clasts have equant and their surface texture varies from rough to moderately smooth. The clast population is dominantly of igneous origin, consisting of vesicular basalt, medium-grained rhyolite, light-gray perlite and cm-scale marekanite with perlite coatings still retaining a bull's-eye texture (Figures $14 \mathrm{E}-\mathrm{G}$ ). The proportion of perlite clasts is less than $30 \%$, while the combined proportion of rhyolite and basalt clasts population is about $60 \%$. This clastic member is defined as a yellow to lightor dark-brown, clast-supported, poorly-sorted, subrounded to very angular, well-cemented, massive, parallel-bedded polymictic conglomerate with a calcite and tuffaceous sandy-muddy matrix (20\%). In terms of mining potential, the low proportion of perlite clasts is here considered of low economic value.

The Las Pilas polymictic conglomerate overlays the fault breccia in a disconformity. The clast composition and angular shapes strongly suggests uplift, erosion, and short transport of local eruptive silicic and mafic products. The nearest source candidates for the silicic and mafic material are the Late Oligocene silicic and mafic volcanic units of the Selene perlite prospect to the east and the Sierra El Chapulín to the west (Figures 2, 3 A-B, and 4). The stratigraphic position of the Las Pilas polymictic conglomerate and its proximity to the aforementioned volcanic sources unequivocally suggests that deposition must postdate the uplift of these nearby Late Oligocene bimodal volcanic rocks.

Moreover, nearby Miocene half-grabens that wrap around the SET also contain a polymictic conglomerate and sandstone (Figure 2) that are tentatively correlative with the conglomerate of the widespread Miocene Baucarit Formation deposited in various synextensional basins across Sonora (SPP, 1987; Palafox-Reyes et al., 1998). The texture, clast composition, stratigraphic position, and mode of deposition of the Las Pilas polymictic conglomerate resemble the conglomerate of the synextensional Baucarit Formation. Tentatively, we consider the Las Pilas polymictic conglomerate correlative with conglomerates of the Baucarit Formation. This interpretation suggests that the Las Pilas polymictic conglomerate was likely deposited during the Early-Middle Miocene and that the Aribabi valley might represent a small half-graben that formed in a still extending continental crust. Active crustal extension in this region is strongly supported by various lines of evidence including historical records of seismicity (Suter, 2001, 2006), instrumentally recorded extensional earthquakes (Castro et al., 2010; Villalobos-Escobar and Castro, 2015), and both detailed structural field data (Suter, 2008a, 2008b, 2015) and coseismic deformation modeling (Suter and Contreras, 2002) of active normal faults.

The members of the volcaniclastic Aribabi unit neither show interstratification or mixture with any of the silicic and/or mafic volcanic units of the Selene perlite prospect (i.e., peperites), nor intrusion by dykes, sills, or hypabyssal rocks. At least at the prospect scale, our field observations demonstrate that deposition of the volcaniclastic Aribabi unit begun after the eruption and uplift of the Late Oligocene Huepari basalt. Therefore, we suggest that deposition in the adjacent Aribabi half-graben likely began in Early Miocene, was probably synextensional but not synvolcanic, and was controlled mainly by the bounding Sierra El Chapulín topographic high (to the west) and the bounding Babidanchic and Selene normal faults (to the east; see section 1.2).

\subsection{Extensional faulting and veining}

A $\sim 5 \mathrm{~km}$ - long, $\sim$ NS-striking fault occurs west of the Selene perlite prospect (Figure 4), here informally named the Babidanchic fault. Although the fault scarp was not observed in the study area, several lines of evidence suggest this is a fault. Evidence includes the local jagged geomorphology (Figures $3 \mathrm{~A}-\mathrm{B}, 5 \mathrm{~A}$ ), the occurrence of the fault breccia (Aribabi unit) in the Babidanchic stream (Figure 14), the displaced volcanic units of the Selene perlite prospect (Figures 4 and 6), and the nearby active normal faults responsible for the long-lasting and still active crustal extensional history of the area (Figures 1 C-D) (Suter, 2001, 2006, 2008a, 2008b, 2015; Suter and Contreras, 2002; Castro et al., 2010; Villalobos-Escobar and Castro, 2015). The west side (hanging wall) dropped a portion of the Babidanchic rhyolitic ignimbrite and the east side (footwall) lifted the entire bimodal volcanic sequence (i.e., the Babidanchic rhyolitic ignimbrite, flow-banded rhyolite, Selene perlite, and the Huepari basalt; Figures, 4 and 5). Therefore, the sense of motion indicates normal faulting most likely associated to EW-oriented extension of the Mexican BREP. Continued extensional deformation along the Babidanchic normal fault led to the uplift and later erosion of the bimodal volcanic sequence and the deposition of the Early Miocene Aribabi unit in the adjacent Aribabi half-graben.

A $~ 1.20 \mathrm{~km}$ - long fault here informally named the Selene fault cuts the Huepari basalt and the Selene perlite flow (Figures 4, 6, 15 A-C). A portion of the Selene fault is sub-parallel to the Babidanchic normal fault and is located between 35 to $50 \mathrm{~m}$ east of the Babidanchic normal fault (Figure 4). It is best exposed in a $\sim 130 \mathrm{~m}$ - long segment that cuts the NW lobe of perlite ore body $I$, were it strikes NNE-SSW and dips steeply $\left(60-70^{\circ}\right)$ towards the west (Figures $5 \mathrm{G}$ and $15 \mathrm{~A}-\mathrm{C}$ ). The fault extends tens of meters farther before it turns sharply $\left(\sim 90^{\circ}\right)$ to the right (Figure $5 G)$. The structural data of the Selene fault are plotted in stereonets of equal-area lower-hemisphere projection 
plots using the computer program of Allmendinger et al. (2013) (Figure 15A). The direction of movement of the hanging wall, revealed by the vertical slickenside lineations, slickenfibers, and the topography across the fault scarp (Figures 15 B-C), was downward; therefore, it is identified as a normal fault. The Selene normal fault also affects the NE perlite lobe of ore body $I$, but because the fault scarp is not preserved, it is inferred to occur along the steep cliff (Figure 5G). Petrographic examinations of perlitic samples collected east of the Selene normal fault plane reveal microfaults consistent with normal dip-slip motion that displaced two generations of perlitic texture (Figures 11 L-P). The Babidanchic and Selene normal faults are aligned with nearby, active, $\mathrm{N}-\mathrm{S}$-trending, and steeply $\mathrm{W}$-dipping normal faults of the Mexican BREP. These active faults correspond to the Pitáycachi, Teras, Otates, Villa Hidalgo, and Granados normal faults that occur north and south the Selene perlite prospect (Suter, 2001, 2008a, 2008b, 2015; Castro et al., 2010; Villalobos-Escobar and Castro, 2015) (Figures $1 \mathrm{~B}-\mathrm{D}$ and 2). The geometric similarity between the Selene, Teras and Otates normal faults, shown in Figure $15 \mathrm{~A}$, suggests that the Selene normal fault might be an additional normal fault segment associated to the rupture of the Bavispe $M_{\mathrm{w}} 7.4$ earthquake on 3 May 1887; however, more structural mapping is required to support this idea particularly between the northern tip of the Selene normal fault and the southern tip of the Otates normal fault. The lack of a fault scarp along the Babidanchic normal fault prohibits direct structural comparisons with the Selene, Teras (Suter, 2008a), Otates (Suter, 2008b), and Pitáycachi (Suter, 2015) normal faults. However, we infer that both the Babidanchic and Selene normal faults are structurally linked to the still active $\sim$ EW-oriented extensional stress field affecting northeastern Sonora, though, the levels of extensional seismicity in the Selene perlite prospect area are rather low relative to its surroundings (e.g., Pitáycachi, Teras, Otates, Villa Hidalgo, and Granados active normal faults) (Suter, 2001; Castro et al., 2010; Villalobos-Escobar and Castro, 2015).

Finally, white botryoidal chalcedony and rare occurrences of both rose chalcedony and white jasper exist in the form of veins in joint planes located near and along the Selene normal fault plane (Figures $15 \mathrm{C}$ and $16 \mathrm{~A}-\mathrm{D})$. The chalcedony veins are 0.5 to $70 \mathrm{~mm}$ - thick and $15 \mathrm{~mm}$ - to $2 \mathrm{~m}$ - long, while the jasper veins vary from 15 to $35 \mathrm{~mm}$ thick and present a blocky texture. All the chalcedony veins strike NNW-SSE and dip steeply towards the SW, whereas a jasper vein strikes NS and dips in the same direction (Figure 16D). The strike and dip of the veins is coplanar relative to the Selene normal fault plane. The vertical orientation of the veins implies that they filled in discontinuity planes that opened due to approximately EW-oriented horizontal tensile principal stresses likely associated with the crustal extension along the Selene normal fault. Together, the vertical orientation of the chalcedony veins, their proximity, and geometric relationship (i.e., parallel orientation and similar dip) relative to the Selene normal fault suggests that they are either syn- or postkinematic extensional veins that filled in joints near the normal fault plane. The presence of veins reveals that hydrothermal fluids migrated towards areas of lower lithostatic pressure during a localized extensional faulting event. This can explain the absence of macroscopic subvertical veins in other lithologies or in undeformed zones within the Selene perlite prospect. Petrographic and field observations of perlitic samples indicate that calcite and quartz filled tensional microcracks, forming microveinlets (Figures 11B and 11K). Further, from the economic point of view, the expansion index of
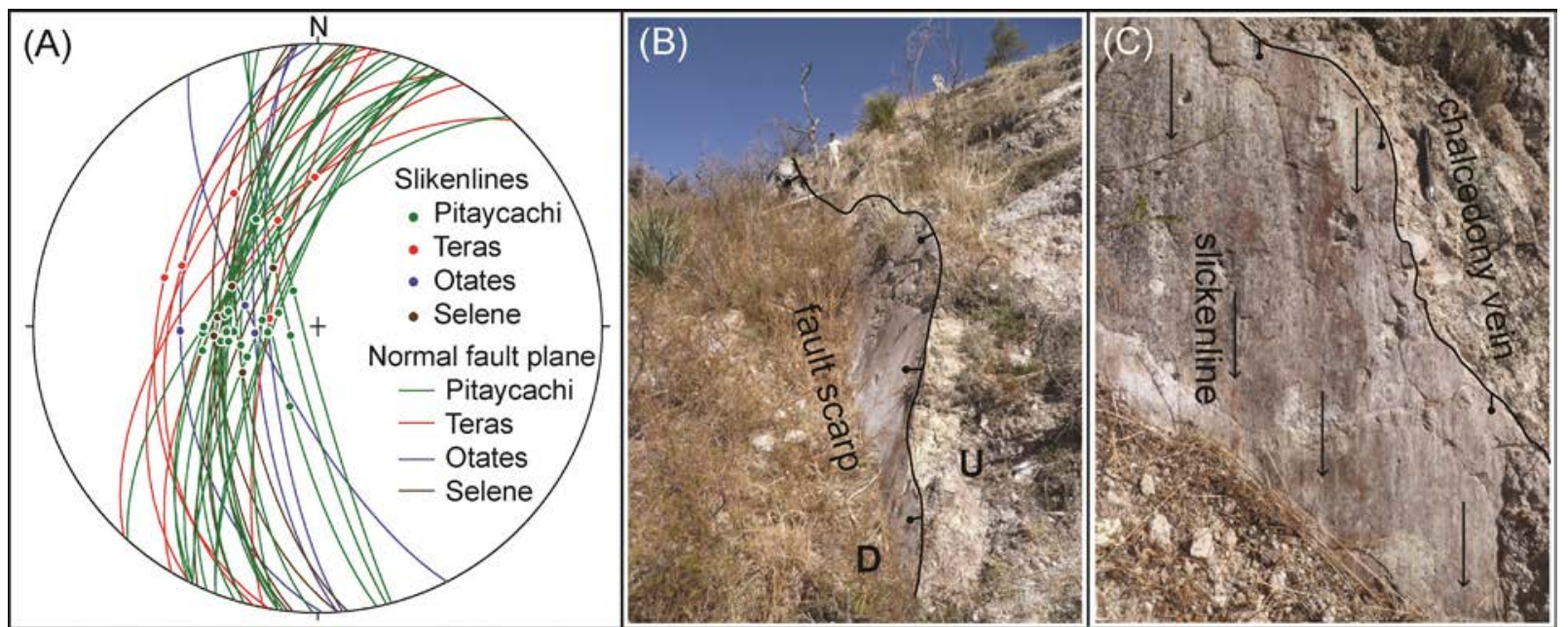

Figure 15. Structural data and representative field photographs of the Selene normal fault scarp (this study) relative to the nearby Teras, Otates, and Pitáycachi active normal faults measured by Suter (2008a, 2008b, 2015, respectively). The Selene normal fault plane and slickenlines plotted in stereonet of equal-area lower-hemisphere projection showing a clear coplanar geometry relative to the Teras, Otates, and Pitáycachi active normal faults (A). Side and frontal views of the Selene normal fault scarp (B and C, respectively). Note chalcedony vein coplanar with the fault plane. Persons in the background of (B) and pen (13.5 cm- long) in (C) for scale. U-Upthrow block; D-Downthrow block. 


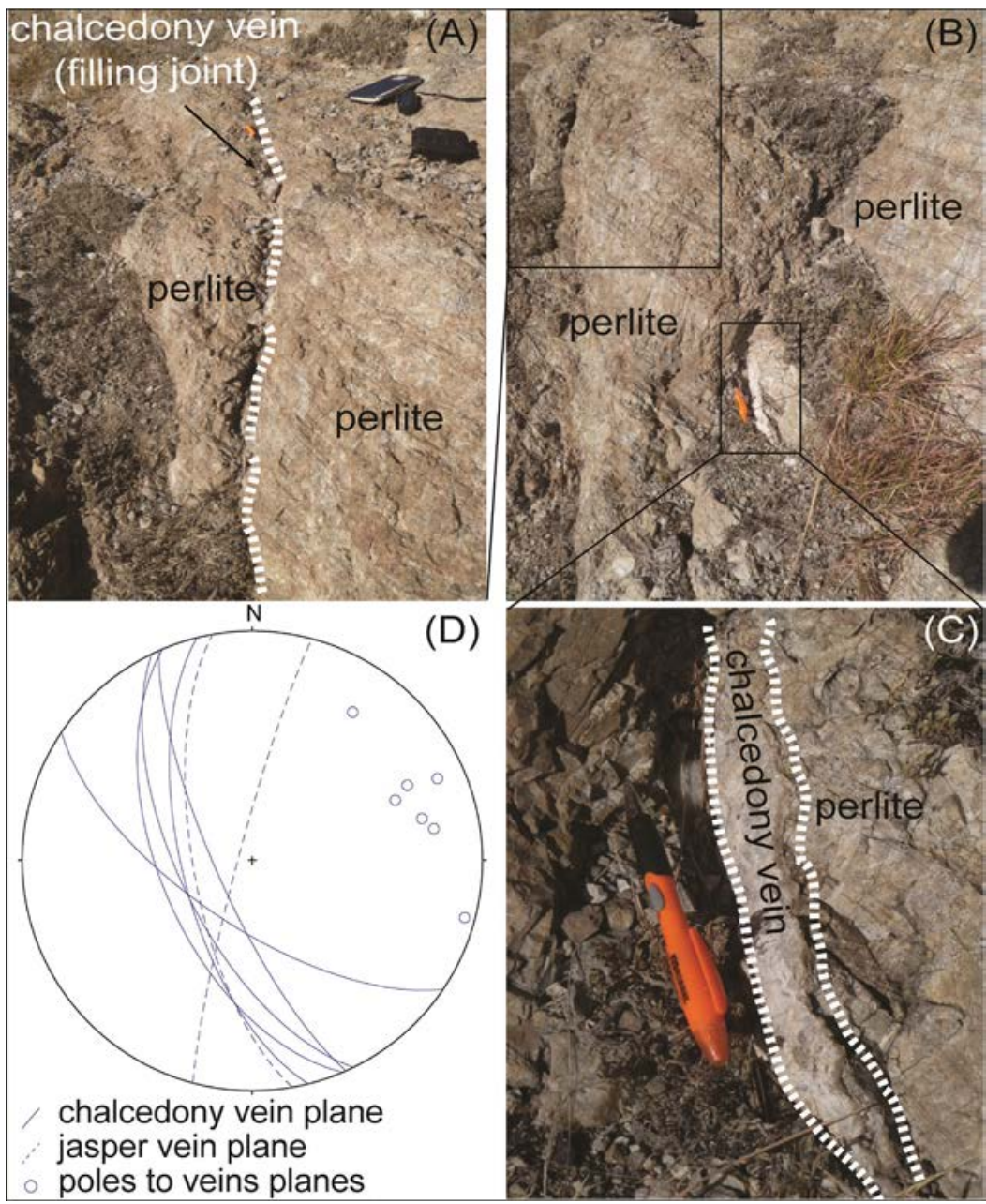

Figure 16. Representative field photographs of botryoidal chalcedony veins cutting the perlitic rocks of perlite ore body $I$ (A-C); and structural data of chalcedony veins plotted in stereonet plot of equal-area lower-hemisphere projection (D). Chalcedony veins strike NNW and dip steeply towards the SW. Some chalcedony veins fill in joints oblique to the Selene normal fault plane and others are coplanar to the fault plane suggesting syn- or postkinematic nature.

the Selene perlite ore is likely to be relatively lower (but only) in zones containing localized chalcedony and calcite macro and microveins, marekanite, red obsidian lenses, and the alteration mineralogy found in small patches.

5.3. Spatial distribution of lithofacies and facies model of the Selene perlite ore deposit

The Babidanchic rhyolitic ignimbrite, the flow-banded rhyolitic lava flow and related (Selene) perlite domecoulee, and the Huepari basalt crop out in the footwall of the Babidanchic normal fault; however, a small resistant portion of the Babidanchic rhyolitic ignimbrite crops out in the hanging wall (Figure 4). This bimodal volcanic sequence dips moderately to the ENE, is next to the NStrending Babidanchic normal fault, and is cut again by the Selene normal fault. Contrariwise, the flat laying terrigenous volcaniclastic Aribabi unit only occurs in the hanging wall of Babidanchic fault and east of the Sierra El Chapulín.

The Selene perlite prospect and surroundings contain material commonly linked to volcanic vent facies deposits including rhyolitic ignimbrites, rhyolitic to basaltic lava flows, and andesitic and rhyolitic tuffs (Almazán-Holguín and Trelles-Monge, 1986; SPP, 1987; CRM, 1994; PalafoxReyes et al., 1998). The rhyolitic ignimbrites represent the explosive products of large silicic vents that lay $(\geq 10 \mathrm{~km})$ outside the Selene perlite prospect. The overlying volcanic facies represent effusive silicic to mafic products sourced at vents that were probably closer to the area of the Selene perlite prospect and controlled by pre-existing normal faults and related fissures (Figure $17 \mathrm{~A}-\mathrm{C}$ ). The ignimbrites commonly covered up vents located near the Selene perlite prospect (Figures 2 and $3 \mathrm{~B}-\mathrm{C}$ ). Lack of interstratified terrigenous volcaniclastic sediments and other pyroclastic deposits suggests neither topographic low nor a typical stratovolcano but rather a moderately elevated volcanic vent complex (controlled by pre-existing normal faults).

The size of the volcanic vents, the eruptive products of which constitute the Selene perlite prospect, cannot be determined precisely but certain estimations can be made. 


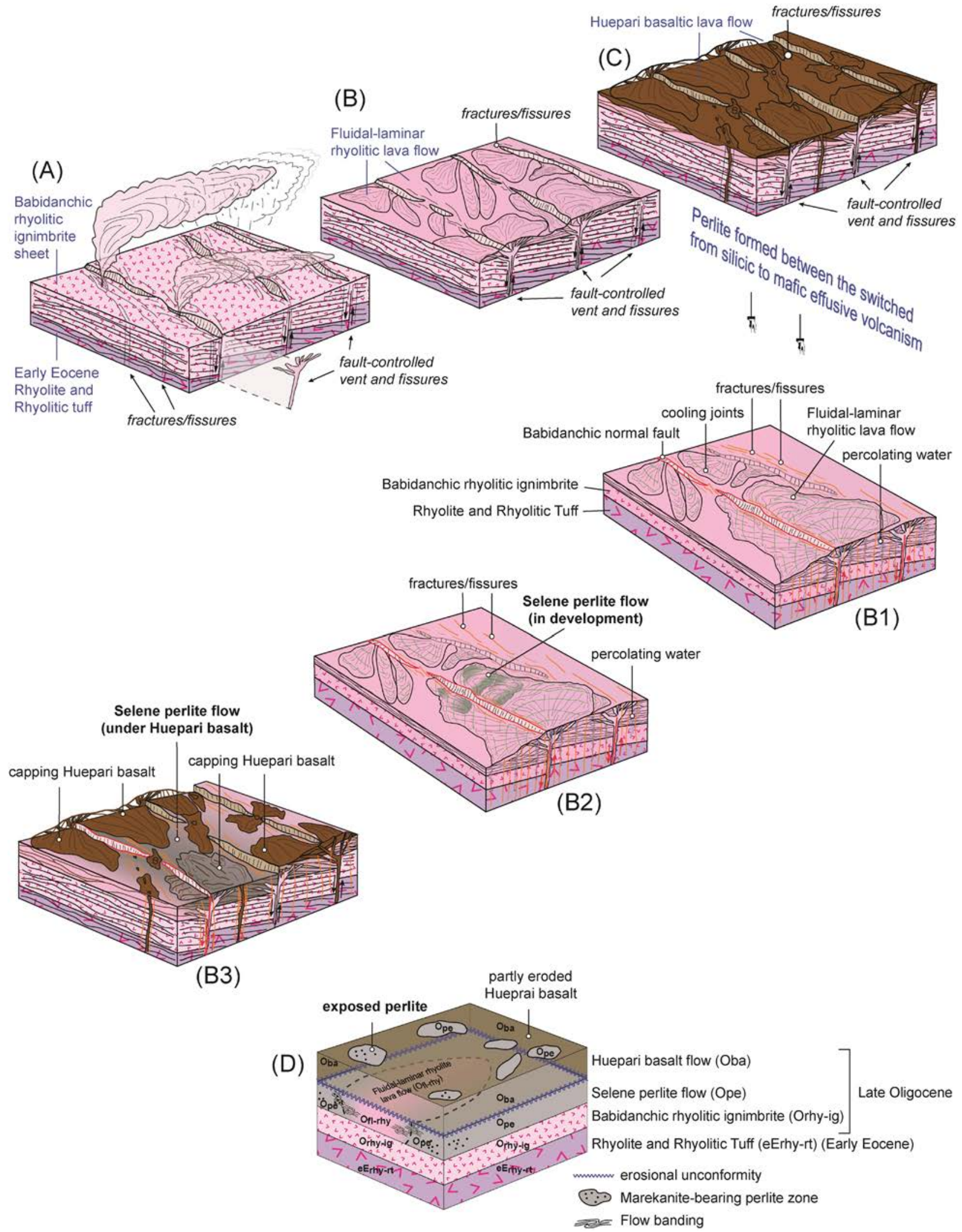

Figure 17. Volcanic facies model illustrating the volcanic evolution in the region around the Selene perlite prospect during the Late Oligocene. Eruption of the Babidanchic rhyolitic ignimbrite from proximal-distal vent sources (A). Eruption of the flow-banded rhyolitic lava flow from near vent sources (B). Eruption of the Huepari basalt from proximal sources (C). Pre-existing normal faults and related fissures controlled the silicic and mafic volcanic vents. Perlite development occurred between the switch from effusive silicic volcanism of rhyolitic composition (e.g., flow-banded rhyolitic lava flow) to effusive mafic volcanism of basaltic composition (e.g., Huepari basalt) (B1-B3). Interpreted volcano-stratigraphic and morphologic current situation of the Selene perlite ore deposit (D). 
The source vents of silicic and mafic lava flows near the Selene perlite prospect were unlikely to exceed the size of the controlling normal faults and fissures $(5-10 \mathrm{~km}$ - long) and were part of a regional volcanic vent complex. Multiple source vents in the Selene perlite prospect are suggested by the vertical and continuous succession of distal ignimbrites, near-vent lava dome-flow facies, proximal basaltic lava flows, and the existence of numerous normal faults and fissures next to silicic and mafic lava flows (Figure 4). None of these volcanic facies are intruded by vent-related hypabyssal bodies, at least within the mapped area.

From bottom to top, the Late Oligocene bimodal volcanic sequence in the Selene perlite prospect records a silicic explosive phase, followed by a silicic effusive phase, and in turn by a waning mafic volcanic phase, all presumably within a synextensional volcanic setting. The continental crust in this region is still extending (e.g., Castro et al., 2010; Villalobos-Escobar and Castro, 2015; Suter, 2015). The Aribabi half-graben clearly records the transition from bimodal volcanism to terrigenous deposition of volcaniclastic material (Aribabi unit) derived from surrounding and uplifted eruptive products. Our volcanic facies model of the Selene perlite prospect shows the potential participation of multiple normal-fault-controlled vents within the southern tip of the SET with contributions likely from outlying silicic vents, caldera or calderas (Figures 1 C-D to 4). Smaller normal-fault-controlled vents might have been within few kilometers $(\leq 10 \mathrm{~km})$ of one another, as suggested by a great abundance of volcanic units of rhyolitic, andesitic, and mafic composition juxtaposed against map-scale normal faults and related fractures scattered throughout the Nacozari Mining District (Figure 2) (Palafox-Reyes et al., 1998).

\subsection{Geologic evolution of the Selene perlite ore prospect}

The geologic evolution of the Selene perlite ore deposit is summarized as follows. The (i) Babidanchic rhyolitic ignimbrite sheet erupted during the Late Oligocene from a vent(s) located outside $(10-20 \mathrm{~km})$ the Selene perlite prospect. The vent(s) was controlled by pre-existing NStrending, steeply dipping normal faults and fissures related to the Mexican BREP; followed by (ii) the eruption of the flow-banded rhyolitic lava flow and domes from a normalfault-controlled vent(s) and its subsequent progressive hydration leading to the formation of marekanites, thin bands of obsidian, and huge amounts of (iii) perlite (i.e., Selene perlite flow); (iv) eruption of the plagioclaseolivine-rich Huepari basalt also through pre-existing normal-fault-controlled vents and/or fissures towards the end of the Late Oligocene or beginning of the Miocene and its deposition over the underlying silicic volcanic units along an erosional unconformity. (v) Normal faulting of this Late Oligocene bimodal volcanic sequence along the NS-trending Babidanchic normal fault probably in the Early Miocene led to the subsequent uplift, partial exposure, and erosion of this bimodal volcanic sequence. This resulted in the formation of the adjacent Aribabi half-graben filled by the (vi) volcaniclastic Aribabi unit no earlier than the Early Miocene. Finally, a (vii) second, but smaller, normal faulting episode along the coplanar Selene normal fault in the post-Early Miocene that hosts syn- or postkinematic chalcedony and calcite veins.

\section{Discussion}

The bimodal volcanic sequence that makes up the Selene perlite prospect, comprised of the lower Babidanchic rhyolitic ignimbrite, the middle flow-banded rhyolitic lava flow and Selene perlite dome-coulee, and the upper Huepari basalt (Figures 4 and 6), is of inferred Late Oligocene age and is part of a widespread silicic to mafic volcanic phase in the Nacozari Mining District (Palafox-Reyes et al., 1998). These volcanic units belong to the Eocene-Early Miocene Upper Volcanic Supergroup of the northern SMO composed mainly of silicic ignimbrites, lavas, intrusions, and subordinate intermediate to mafic lavas (e.g., McDowell and Keizer, 1977; Ferrari et al., 2007; McDowell, 2007).

The inferred Late Oligocene age for the Selene perlite prospect still remains tentative. However, it is well-supported by local lithostratigraphic correlations, that we have made relative to previously directly dated silicic volcanic units that crop out near the Selene perlite prospect. For instance, the El Globo rhyolite crops out $\sim 50 \mathrm{~km}$ northwest of the Selene perlite prospect and $5 \mathrm{~km}$ north of the La Caridad Copper Porphyry Mine. Livingston (1973) obtained a K/Ar age of $24 \pm 0.4 \mathrm{Ma}$ (on biotite) for the El Globo rhyolite. For the same rhyolite, Worcester (1976) obtained a K/Ar age of 24 $\pm 0.5 \mathrm{Ma}$ (on biotite and sericite). Both workers interpreted the $\mathrm{K} / \mathrm{Ar}$ age as a Late Oligocene emplacement age. In the nearby Los Alisos Copper Porphyry prospect, located $\sim 55 \mathrm{~km}$ NW of the Selene perlite prospect, the El Globo rhyolite is sandwiched by a local ferric conglomerate at the bottom and an Early Miocene clastic sequence at the top composed of lower basaltic lavas and upper conglomerates and sandstones (Rascón-Heimpel et al., 2012). The ferric conglomerate unconformably overlies rhyolitic dome facies deposits of the Late Cretaceous-late Early Eocene (ca. 90 - $55 \mathrm{Ma}$ ) Tarahumara formation. West of the Selene perlite $(\leq 65 \mathrm{~km})$, rhyolitic ignimbrites yield one biotite and two hornblende ${ }^{40} \mathrm{Ar} /{ }^{39} \mathrm{Ar}$ plateau ages at $26.97 \pm 0.06$, $27.32 \pm 0.06$, and $27.25 \pm 0.09 \mathrm{Ma}$, respectively (GonzálezLeón et al., 2000, 2010). Rhyolitic ignimbrites $115 \mathrm{~km}$ south of Selene perlite prospect yielded a ${ }^{40} \mathrm{Ar} /{ }^{39} \mathrm{Ar}$ age of 33 Ma (sanidine: Gans, 1997), K/Ar ages of $33.5 \mathrm{Ma}$ (plagioclase) and 21.2 Ma (K-feldspar) (McDowell et al., 1997) all interpreted as ignimbritic and dome emplacement ages during the waning stages of extensive Late Oligocene silicic ignimbritic volcanism of the northern SMO. This emplacement age establishes a direct volcanogenic link with the Eocene-Early Miocene Upper Volcanic Supergroup. 
These directly dated silicic volcanic units of rhyolitic composition and their contemporaneous nature relative to the silicic volcanic units of the Selene perlite prospect provide an estimate of the timing of silicic volcanism across northeastern Sonora which has also overlapped with crustal thinning since the middle Tertiary linked to the BREP (Suter, 2008a, 2008b, 2015). Extensional deformation is still active in northeastern Sonora along NS-trending, steeply W-dipping, active normal faults that occur immediately north (i.e., Otates, Teras, and Pitáycachi faults) and south (i.e., Villa Hidalgo and Granados faults) of the Selene perlite prospect (Figure 1) (Suter, 2001, 2015; Castro et al., 2010; Villalobos-Escobar and Castro, 2015). These major normal faults, along with smaller ones, define a $\sim 200 \mathrm{~km}$ - long by $\sim 150 \mathrm{~km}$ - wide extensional zone that affects the western flank of the northern SMO silicic large igneous province in contrast with its relatively unextended core (Figure 1) (see Villalobos-Escobar and Castro, 2015; Suter, 2015). Moreover, the upper basalts of the Oligocene-Miocene bimodal sequence, located at Yecora-Ocampo region ( $100 \mathrm{~km}$ south of the Selene perlite prospect), have been dated by K/Ar at 17 and 18.4 Ma (Cochemé and Demant, 1991; McDowell, 2007; respectively). This implies that the Selene perlite flow must have formed no earlier than the Late Oligocene ( $c a . \geq 28 \mathrm{Ma}$ ) in an already extending continental crust. Moreover, recent geologic mapping and U-Pb zircon ages in the Guazapares Mining District of southwestern Chihuahua (still in the northern SMO) document synextensional silicic- to- mafic volcanism between $c a$. 27.5 to $23 \mathrm{Ma}$ (Late Oligocene to Early Miocene) controlled by NNW-striking high-angle normal faults (Murray et al., 2013, 2014; Murray and Busby, 2015). Synextensional bimodal volcanism is also reported farther south within the extended portion of the SMO silicic large igneous province (Aguirre-Díaz and McDowell, 1993; Ferrari et al., 2013; Duque-Trujillo et al., 2014a, 2014b). Bryan et al. (2013) propose that the SMO silicic large igneous province corresponds to the pre- to syn-rift volcanic event to the Gulf of California rift. This is because from about $30 \mathrm{Ma}$ to $24 \mathrm{Ma}$, extension and SMO volcanism were overlapping spatially and temporally.

The rhyolitic and basaltic lithofacies of the Selene perlite prospect occur in the southern tip of the SET, which has been stretched by NW- and NS-trending normal faults linked to the Mexican BREP (Castro et al., 2010; VillalobosEscobar and Castro, 2015) since the Late Oligocene (ca. 28 m.y.) (Gans, 1997). The NS-trending Babidanchic and Selene normal faults line up with nearby NS-trending active normal faults (Figures 1 B-D and 2). We suggest that the formation, preservation, and exposure of the Selene perlite deposit (and probably other perlite deposits in the region) were influenced by the pervasive normal faulting across the region. The tectonic history and seismic activity led to the formation of faults and fractures/fissures across the region. First, normal faulting and related fractures/ fissures controlled the location of silicic volcanism and later waning mafic volcanism, as documented in other regions of the SMO (Bryan et al., 2013; Murray et al., 2013; Duque-Trujillo et al., 2014a, 2014b; Murray et al., 2015; Murray and Busby, 2015). These structural discontinuities promoted pathways that channelized both rising magmas and gases of effusive rhyolitic domes and lava flows and later basaltic lavas (proximal and vent volcanic facies) as well as percolating meteoric waters. The interactions between rapidly cooling rhyolitic lava flows with circulating near-surface or underground water led to the hydration of rhyolitic lava flows (i.e., the flow-banded rhyolitic lava flow), obsidian, and large amounts of perlite prior to the eruption of the capping Huepari basalt directly on the Selene perlite. Yet, hydration of the rhyolitic rocks may have continued after the eruption of the Huepari basalt. Second, the Huepari basalt preserved the Selene perlite flow from later devitrification and total erosion because it sealed it. Third, regional crustal thinning, but in particular normal faulting along both the Babidanchic and Selene normal faults, was responsible for the uplift, subsequent partial erosion, and exposure of the Selene perlite flow (and overburden) to its present topographic conditions (favoring open-pit mining operations). Figures 17 B1-B3 illustrate schematically the progressive development of the Selene perlite ore deposit prior to the eruption of the overlying Huepari basalt. Figure 17D depicts the interpreted volcanostratigraphic and morphologic situation of the Selene perlite flow based upon the available geologic data.

The lack of direct dates of both the flow-banded rhyolitic lava flow (i.e., parent rock of the Selene perlite) and the capping Huepari basalt hamper the estimation of the time of perlite formation. Our petrographic observations indicate that the alkali feldspar found in the flow-banded rhyolitic lava flow and the plagioclase found in the capping Huepari basalt can bracket the age of perlite formation if directly dated with either the ${ }^{40} \mathrm{Ar} /{ }^{39} \mathrm{Ar}$ or K/Ar method. Alternatively, the approximate timing of perlite development can be estimated by dating the glassy groundmass with either dating technique. Finally, the same normal faults and related fractures/fissures that provided conduits for the ascent of rhyolitic magmas and circulation of meteoric waters in the subsurface also allowed the circulation and precipitation of the observed hydrothermal fluids (i.e., hematite, calcite, and chalcedony) that affect the bimodal volcanic sequence (Figures 4 and $16 \mathrm{~A}-\mathrm{C}$ ).

The proposed geologic model of the Selene perlite flowdome explains the close spatial and temporal proximity that exists between perlites and extensional structures across Sonora, Chihuahua, and Durango where synvolcanic extensional faulting is well-documented (e.g., AguirreDíaz and McDowell, 1993; Murray et al., 2013, 2014; Murray and Busby, 2015). The small proportions of gangue minerals and obsidian found in the Selene perlite prospect represent impurities that affect (decrease) the expansion index of the Selene perlite ore. Previous work (AlmazánHolguín and Trelles-Monge, 1986) and also our own 
laboratory expandability tests performed in two commercial laboratories (Silbrico Corporation and the Perlite Testing Laboratory of the New Mexico Bureau of Geology \& Mineral Resources) indicate that the Selene perlite ore is of commercial quality with applications including acoustic, lightweight aggregate, construction, ambient and low- and high-temperature insulation, and cryogenics (Vidal-Solano et al., 2014b).

The Sierra El Chapulín and both the NS-trending Babidanchic and Selene normal faults bound the west and east sides of the Aribabi valley, respectively (Figures 2 and 3). The Sierra El Chapulín is an intermediate-mafic volcanic edifice composed mainly of andesitic lavas, andesitic tuffs with lesser rhyolitic lavas, rhyolitic tuffs, and basalts of inferred Oligocene age (Palafox-Reyes et al., 1998). The Aribabi half-graben and its bounding normal faults occur within the aforementioned ( $200 \times \sim 150 \mathrm{~km}$ ) extensional zone (Figures 1 B-C) and controlled the deposition of the Early Miocene volcaniclastic Aribabi unit and Quaternary alluvium (Figures 3 and 4). This supports the idea that the Babidanchic and Selene normal faults are likely controlled by the same EW-oriented extensional stress field that controls the outlying NS-trending active normal faults (Figures 1 B-C). Further, the Aribabi half-graben might have begun to form coevally with the onset of the nearby Pitáycachi, Teras, Otates, Villa Hidalgo, and Granados active normal faults; however, the geomorphologic expression of the Aribabi half-graben is not as obvious as it is along these active normal faults. This might be due to the low levels of extensional seismicity documented within the Selene perlite prospect and the Aribabi half-graben region (Suter, 2001; Castro et al., 2010; Villalobos-Escobar and Castro, 2015). The sedimentologic nature, stratigraphic position, geomorphologic setting, and the proximity of the Las Pilas polymictic conglomerate with respect to normal faults resemble the nearby Miocene polymictic conglomerates and sandstones flanking the SET (Palafox-Reyes et al., 1998). Map and geologic data are currently insufficient to demonstrate synextensional deposition of the Aribabi unit; however, this possibility is not excluded given the extensional history across Sonora. Both the here proposed volcanic facies model and geologic evolution of the Selene perlite prospect support the idea of Late Oligocene-Early Miocene synextensional volcanism in the study area. This scenario is similar to what has been well-documented in other regions of the SMO silicic large igneous province (e.g., Aguirre-Díaz and Labarthe-Hernández, 2003; Murray et al., 2013, 2014; Duque-Trujillo et al., 2014a, 2014b; Murray and Busby, 2015). Currently, such widespread synextensional volcanism is interpreted as the pre- to syn-rift volcanic event to the active Gulf of California rift (Bryan et al., 2013; Duque-Trujillo et al., 2014a, 2014b). Numerous perlite occurrences formed near or in an extensional setting related to either the Mexican BREP or the proto-Gulf of California rift (Vidal-Solano et al., 2014a).

\section{Conclusions}

The State of Sonora, Mexico holds several poorly geologically understood and under-studied volcanogenicrelated perlite ore deposits, of which probable reserves and expansion indexes remain known only on a preliminary basis. Many of these perlite ore deposits exist in tectonically extended areas traversing from coastal to eastern Sonora. Our geologic mapping of the Selene perlite ore deposit, formerly Babidanchic perlite, covers an area of $16 \mathrm{~km}^{2}$ and documents four additional mappable perlite outcrops proximal to the already known ones. Therefore, the amount of potential perlite reserves in the Selene perlite prospect has increased significantly; however, a formal estimation of the reserves is expected. The flow-banded rhyolitic lava flow of inferred Late Oligocene age is the only silicic unit that hosts perlites. The (Selene) perlite dome-coulee formed prior to the eruption of the capping Huepari basalt, which was deposited along an erosional unconformity. In general, all the mapped perlite bodies occur near normal faults and related fractures/fissures, the surface expressions of which are now tributary streams, gullies, and rivers. Normal faulting in the region, including the Babidanchic and Selene normal faults, linked to the Mexican BREP, strongly influenced the formation, preservation, and exposure of the Selene perlite flow. In addition to promoting volcanic fissure vent silicic and mafic magmatism across the region, these structural discontinuities increased the permeability of the subsurface, and channeled percolating meteoric waters and rising gases through a network of interconnected fissures. The water-lava interactions led to the hydration of the flow-banded rhyolitic lava flow and later formation of huge amounts of perlite. The Selene perlite flow was partly preserved by the capping Huepari basalt, but continued normal faulting and subsequent erosion exposed it to its present topographic conditions. Normal faulting across the region also developed the Aribabi half-graben, filled by the Early Miocene volcaniclastic Aribabi unit. Deposition of the Aribabi unit sharply marks the end of Late Oligocene bimodal volcanism and the onset of (synextensional?) terrigenous clastic deposition in a NS-oriented structural basin, at least across the Selene perlite prospect region.

The Late Oligocene-Miocene bimodal volcanic sequence of the Selene perlite prospect belongs to the Eocene to Early Miocene Upper Volcanic Supergroup of the northern SMO silicic large igneous province. We infer that the eruption of explosive silicic volcanism and effusive silicic and mafic lavas in the Selene perlite prospect were part of a regional synextensional volcanic event, previously well-documented in the northern (Demant et al., 1989; Cochemé and Demant, 1991; Aguirre-Díaz and McDowell, 1993; Ferrari et al., 2007; McDowell, 2007; Bryan et al., 2013; Murray et al., 2013, 2014; Murray and Busby, 2015), central (DuqueTrujillo et al., 2014a, 2014b), and southern SMO silicic large igneous province (Aguirre-Díaz and Labarthe-Hernández, 
2003; Ferrari et al., 2013). Synextensional silicic volcanism and water availability were essential elements that favor the generation of perlite ore deposits in Sonora, and likely in other regions across the SMO silicic large igneous province. Therefore, the interaction of meteoric and/or underground water, rising gases, and Late Oligocene age and/or younger synextensional silicic volcanism near normal faults and related fractures/fissures are important features for a perlite exploration model in Sonora and other regions within the SMO. This geologic model explains the spatial-temporal proximity between perlites and extensional structures across Sonora. Although the geologic evolution of the Selene perlite ore deposit is interpreted to be linked to a synextensional volcanic setting (i.e., Mexican BREP), this does not mean that perlites are diagnostic extrusive rocks of syntectonic silicic volcanism. Finally, both our volcanic facies model and the evolutionary geologic model of the Selene perlite ore deposit are in accord with the idea that extensional deformation controlled the locus of magmatism in the SMO silicic large igneous province rather than the other way around (Aguirre-Díaz and Labarthe-Hernández, 2003; Bryan et al., 2013; Duque-Trujillo et al., 2014a).

\section{Acknowledgements}

We thank Bryan Scott and Luca Ferrari for their constructive reviews and comments and two other anonymous reviewers (TM and ECG), which improved the early version of the manuscript. The comments of Damian Nance also improved the quality of the manuscript. Research Grant \#180784 from Consejo Nacional de Ciencia y Tecnología (CONACYT) to Jesús Roberto Vidal Solano. We thank Jorge A. Hinojosa-Prieto who assisted during the fieldwork, and Mariano Vazquez Coronado ("Chano") and other locals for their hospitality and for showing us useful trails.

\section{References}

Acuña, R.A., Bonachela, S., Magán, J.J., Marfà, O., Hernández, J.H., Cáceres, R., 2013, Reuse of rockwool slabs and perlite grow-bags in a low-cost greenhouse: Substrates physical properties and crop production: Scientia Horticulturae, 160, 139-147.

Aguirre-Díaz, G.J., Labarthe-Hernández, G., 2003, Fissure ignimbrites: Fissure-source origin for voluminous ignimbrites of the Sierra Madre Occidental and its relationships with Basin and Range faulting: Geology, 31, 773-776.

Aguirre-Díaz, G.J., McDowell, F.W., 1991, The Volcanic section at Nazas, Durango, Mexico, and the possibility of widespread Eocene volcanism within the Sierra Madre Occidental: Journal of Geophysical Research, 96, 13373-13388.

Aguirre-Díaz, G.J., McDowell, F.W., 1993, Nature and timing of faulting and synextensional magmatism in the southern Basin and Range, central-eastern Durango, Mexico: Geological Society of America Bulletin, 105, 1435-1444.

Akkaya, R., 2012, Removal of radio nuclides of the U- and Th- series from aqueous solutions by adsorption onto Polyacryamide-expanded perlite: Effects of $\mathrm{pH}$, concentration and temperature: Nuclear Instruments and Methods in Physics Research A, 688, 80-83.

Allen, S.R., McPhie, J., 2002, The Eucarro Rhyolite, Gawler Range Volcanics, South Australia: A> $675 \mathrm{~km}^{3}$, compositionally zoned lava of Mesoproterozoic age: Geological Society of America Bulletin, 114, 1592-1609.

Allmendinger, R.W., Cardozo, N.C., Fisher, D., 2013, Structural Geology Algorithms: Vectors and Tensors: Cambridge, England, Cambridge University Press, 289 p.

Almazán-Holguín, O.F., Trelles-Monge, S.A., 1986, Geología de los depósitos de perlita del municipio de Huachinera, Sonora: Hermosillo, Sonora, México, Universidad de Sonora, tesis de licenciatura, $64 \mathrm{p}$.

Armstrong, R.L., Ward, P., 1991, Evolving geographic patterns of Cenozoic magmatism in the North American Cordillera: The temporal and spatial association of magmatism and metamorphic core complexes: Journal of Geophysical Research, 96, 13201-13224.

Arriaga-Meléndez, H., López-Escalona, J., López Reyes, J.E., TeránOrtega, L.A., Castro-Escárrega, J.J., Díaz-Salgado, C., Espinoza Beltrán, C.C., Vázquez Mendoza, R., 2008, Carta geológico-minera Estado de Sonora, 1:250000: Pachuca, Hidalgo, México, Servicio Geológico Mexicano, 1 mapa.

Asaduzzamana, M., Kobayashi, Y., Mondal, Md.F., Ban, T., Matsubara, H., Adachi, F., Asao, T., 2013, Growing carrots hydroponically using perlite substrates: Scientia Horticulturae, 159, 113-121.

Atwater, T., 1970, Implications of plate tectonics for the Cenozoic tectonic evolution of western North America: Geological Society of America Bulletin, 81, 3513-3536.

Atwater, T., Stock, J., 1998, Pacific-North America Plate tectonics of the Neogene southwestern United States; an update, in Ernst, W.G., Nelson, C.A. (eds.), Integrated Earth and environmental evolution of the southwestern United States: The Clarence A. Hall, Jr. volume: Columbia, Bellwether Publishing, 393-420.

Austin, G.S., Barker, J.M., 1998, Commercial perlite deposits of New Mexico and North America, in $49^{\text {th }}$ field conference: Las Cruces Country New Mexico, USA, New Mexico geological society guidebook, 271-277.

Bennett, S.E.K., Oskin, M.E., 2014, Oblique rifting ruptures continents: Example from the Gulf of California shear zone: Geology, 42, 215-218.

Bide, T., Brown, T.J., Hobbs, S.F., Idoine, N., 2014, United Kingdom Minerals Yearbook 2013: London, UK, British Geological Survey, Open-Report OR/14/036, 91 p.

Bolen, W.P., 2000, Mineral Commodity Summaries Annual Publication: Perlite, available online at <http://minerals.usgs.gov/minerals/pubs/ commodity/perlite/520400.pdf $>$, last visited on 8 February 2016.

Bolen, W.P., 2011a, 2009 Minerals Yearbook Perlite [Advance Release], U.S. Geological Survey (USGS) Minerals Yearbook, available online at <http://minerals.usgs.gov/minerals/pubs/commodity/perlite/ myb1-2009-perli.pdf $>$ last visited on 8 February 2016.

Bolen, W.P., 2011b, 2010 Minerals Yearbook Perlite [Advance Release], U.S. Geological Survey (USGS) Minerals Yearbook, available online at <http://minerals.usgs.gov/minerals/pubs/commodity/perlite/ myb1-2010-perli.pdf $>$, last visited on 8 February 2016.

Bolen, W.P., 2014, 2012 Minerals Yearbook Perlite [Advance Release], U.S. Geological Survey (USGS) Minerals Yearbook, available online at <http://minerals.usgs.gov/minerals/pubs/commodity/perlite/ myb1-2012-perli.pdf $>$, last visited on 8 February 2016.

Bolen, W.P., 2015, Mineral Commodity Summaries Annual Publication: Perlite, available online at <http://minerals.usgs.gov/minerals/ pubs/commodity/perlite/mcs-2015-perli.pdf $>$, last visited on 8 February 2016.

British Geological Survey (BGS), 2004, World mineral production 19982002: production: exports: imports: Keyworth, Nottingham, UK, British Geological Survey, Mineral Programme Publication No. 16, $111 \mathrm{p}$.

British Geological Survey (BGS), 2007, World mineral production 2001-05: Keyworth, Nottingham, UK, British Geological Survey, Technical Document, 81 p. 
British Geological Survey (BGS), 2010, World mineral production 20042008: Keyworth, Nottingham, UK, British Geological Survey, Technical Document, $111 \mathrm{p}$.

Bryan, S.E., Ferrari, L., 2013, Large igneous provinces and silicic large igneous provinces: Progress in our understanding over the last 25 years: Geological Society of America Bulletin, 125, 1053-1078.

Bryan, S.E., Ferrari, L., Reiners, P.W., Allen, C.M., Petrone, C.M., Ramos-Rosique, A., Campbell, I.H., 2008, New Insights into Crustal Contributions to Large-volume Rhyolite Generation in the midTertiary Sierra Madre Occidental Province, Mexico, Revealed by U-Pb Geochronology: Journal of Petrology, 49, 47-77.

Bryan, S.E., Orozco-Esquivel, T., Ferrari, L., López-Martínez, M., 2013, Pulling apart the mid to late Cenozoic magmatic record of the Gulf of California: Is there a Comondú arc?, in Gomez-Tuena, A., Straub, S.M., Zellmer, G.F. (eds.), Orogenic Andesites and Crustal Growth: Geological Society of London Special Publication 385, 389-407.

Bustillo-Sáynez, G., Gómez-Gutiérrez, E., 1965, Yacimiento de Perlita "El Tigre”, Municipio de Guaymas, Sonora: Hermosillo, Sonora, México, Consejo de Recursos Naturales No Renovables, Archivo Técnico SIGMA-CRM TI 260015-3, 8 p.

Calmus, T., Pallares, C., Maury, R.C., Aguillón-Robles, A., Bellon, H., Benoit, M., Michaud, F., 2011, Volcanic Markers of the PostSubduction Evolution of Baja California and Sonora, Mexico: Slab Tearing Versus Lithospheric Rupture of the Gulf of California: Pure and Applied Geophysics, 168, 1303-1330.

Cameron, K.L., Nimz, G.J., Kuentz, D., Niemeyer, S., Gunn, S., 1989, Southern Cordilleran basaltic andesite suite, southern Chihuahua, Mexico: a link between Tertiary continental arc and flood basalt magmatism in North America: Journal of Geophysical Research, 94, 7817-7840.

Cameron, M., Bagby, W.C., Cameron, K.L., 1980, Petrogenesis of voluminous mid-Tertiary ignimbrites of the Sierra Madre Occidental: Contributions to Mineralogy and Petrology, 74, 271-284.

Castro, R.R., Shearer, P.M., Astiz, L., Suter, M., Jacques-Ayala, C., Vernon, F., 2010, The long-lasting aftershock series of the 3 May $1887 \mathrm{Mw}$ 7.5 Sonora earthquake in the Mexican Basin and Range Province: Bulletin of the Seismological Society of America, 100, 1153-1164.

Celik, A.G., Depci, T., Kilic, A.M., 2014, New lightweight colemaniteadded perlite brick and comparison of its physicomechanical properties with other commercial lightweight materials: Construction and Building Materials, 62, 59-66.

Chakir, A., Bessiere, J., Kacemi, K.E.L., Marouf, B., 2002, A comparative study of the removal of trivalent chromium from aqueous solutions by bentonite and expanded perlite: Journal of Hazardous Materials, B95, 29-46.

Cobo-Rivera, J.M., Valdez-Salas, B., Carrillo-Beltrán, M., 2010, Minerales Industriales del Estado Peninsular de Baja California, Mexico: Revista Electrónica INTEC, 1, 3-14.

Cochemé, J.J., Demant, A., 1991, Geology of the Yécora area, northern Sierra Madre Occidental, Mexico, in Pérez-Segura, E., JacquesAyala, C., eds., Studies of Sonoran Geology: Geological Society of America Special Paper 254, 81-94.

Consejo de Recursos Minerales (CRM), 1994, Geological-Mining Monograph of the State of Sonora: Pachuca, Hidalgo, México. Monograph, $220 \mathrm{p}$.

Corral-Gastélum, R., Ruíz-Romo, T., Hernández-Rábago, P.I., 1999, Carta geológico-minera San Felipe H11-3 Baja California y Sonora, 1:250000: Pachuca, Hidalgo, México, Servicio Geológico Mexicano, 1 mapa.

Davis, B.K., McPhie, J., 1996, Spherulites, quench fractures and relict perlite in a Late. Devonian rhyolite dyke, Queensland, Australia: Journal of Volcanology and Geothermal Research, 71, 1-11.

Daza, A., Santamaría, C., Rodríguez-Navarro, C.D., Camacho, M., Orive, R., Temprano, F., 2000, Perlite as a carrier for bacterial inoculants: Soil Biology and Biochemistry, 32, 567-572.

Demant, A., Cochemé, J.J., Delpretti, P., Piguet, P., 1989, Geology and petrology of the Tertiary volcanics of the northwestern Sierra Madre Occidental, Mexico: Bulletin Societe Géologique France, 8, 737-748.
Denton, J.S., Tuffen, H., Gilbert, J.S., Odling, N., 2009, The hydration and alteration of perlite and rhyolite: Journal of the Geological Society, London, 166, 895-904.

Denton, J.S., Tuffen, H., Gilbert, J.S., 2012, Variations in hydration within perlitised rhyolitic lavas-evidence from Torfajökull, Iceland: Journal of Volcanology and Geothermal Research, 223/224, 64-73.

Dickinson, W.R., 2002, The Basin and Range Province as a Composite Extensional Domain: International Geology Review, 44, 1-38.

Doğan, M., Alkan, M., 2004, Some physicochemical properties of perlite as an absorbent: Fresenius Environmental Bulletin, 13, 251-257.

Duque-Trujillo, J., Ferrari, L., Norini, G., López-Martínez, M., 2014a, Miocene faulting in the southwestern Sierra Madre Occidental, Nayarit, Mexico: kinematics and segmentation during the initial rifting of the southern Gulf of California: Revista Mexicana de Ciencias Geológicas, 31, 283-302.

Duque-Trujillo, J., Ferrari, L., Orozco-Esquivel, T., López-Martínez, M., Lonsdale, P., Bryan, S.E., Kluesner, J., Piñero-Lajas, D., Solari, L., 2014b, Timing of rifting in the southern Gulf of California and its conjugate margins: Insights from the plutonic record: Geological Society of America Bulletin, published online as doi:10.1130/ B31008.1.

Ennis, D.J., 2011, Perlite mining and reclamation in the no aqua peaks, Taos County, New Mexico, in 62nd Field Conference Geology of the Tusas Mountains-Ojo Caliente: New, Mexico, USA, New Mexico Geological Society Guidebook, 409-418.

Ferrari, L., Valencia-Moreno, M., Bryan, S., 2007, Magmatism and tectonics of the Sierra Madre Occidental and its relation with the evolution of the western margin of North America, in AlanizÁlvarez, S.A., Nieto-Samaniego, Á.F. (eds.), Geology of Mexico: Celebrating the Centenary of the Geological Society of México: Geological Society of America Special Paper 422, 1-39.

Ferrari, L., López-Martínez, M., Orozco-Esquivel, T., Bryan, S.E., Duque-Trujillo, J., Lonsdale, P., Solari, L.A., 2013, Late Oligocene to Middle Miocene rifting and synextensional magmatism in the southwestern Sierra Madre Occidental, Mexico: The beginning of the Gulf of California rift: Geosphere, 9, 1161-1200.

Friedman, I., Long, W., 1984, Volcanic glasses, their origins and alteration processes: Journal of Non-Crystalline Solids, 67, 127-133.

Friedman, I.I., Long, W.D., Smith, R.L., 1963, Viscosity and water content of rhyolite glass: Geophysical Research, 68, 6523-6535.

Gans, P.B., 1997, Large-magnitude Oligo-Miocene extension in southern Sonora: Implications for the tectonic evolution of northwest Mexico: Tectonics, 16, 388-408.

García-Martínez, D., Stanley, R., Garza, M., Roldán-Quintana, J., Mendívil-Quijada, H., 2014, Ca. 13 Ma strike-slip deformation in coastal Sonora from a large-scale, en-echelon, brittle-ductile, dextral shear indicator: implications for the evolution of the California rift: Geofísica Internacional, 53-4, 435-456.

González-León, C., McIntosh, W.C., Lozano-Santacruz, R., ValenciaMoreno, M., Amaya-Martínez, R., Rodríguez-Castañeda, J.L., 2000, Cretaceous and Tertiary sedimentary, magmatic, and tectonics evolution of north-central Sonora (Arizpe and Bacanuchi quadrangles), northwest Mexico: Geological Society of America Bulletin, 112, 600-611.

González-León, C.M., Valencia, V.A., López-Martínez, M., Bellon, H., Valencia-Moreno, M., Calmus, T., 2010, Arizpe sub-basin: A sedimentary and volcanic record of Basin and Range extension in north-central Sonora, Mexico: Revista Mexicana de Ciencias Geológicas, 27, 292-312.

González-León, C.M., Solari, L., Solé, J., Ducea, M.N., Lawton, T.F., Bernal, J.P., González Becuar, E., Gray, F., López Martínez, M., Lozano Santacruz, R., 2011, Stratigraphy, geochronology, and geochemistry of the Laramide magmatic arc in north-central Sonora, Mexico: Geosphere, 7, 1392-1418.

Gutarowska, B., Matusiak, K., Borowski, S., Rajkowska, A., Brycki, B., 2014, Removal of odorous compounds from poultry manure by microorganisms on perlite-bentonite carrier: Journal of Environmental Management 141, 70-76. 
Haines, S.H., van der Pluijm, B., 2008, Clay quantification and Ar-Ar dating of synthetic and natural gouge: Application to the Miocene Sierra Mazatán detachment fault, Sonora, Mexico: Journal of Structural Geology, 30, 525-538.

Haines, S.H., van der Pluijm, B.A., 2012, Patterns of mineral transformations in clay gouge, with examples from low-angle normal fault rocks in the western USA: Journal of Structural Geology, 43, 2-32.

Henry, C.D., Aranda-Gómez, J.J., 1992, The real southern Basin and Range: Mid-to-late Cenozoic extension in Mexico: Geology, 20, 701-704.

Hernández-Ávila, J.A., 2000, Asesoría geológica al fundo Minero "La Eva" Municipio de Madera, Chihuahua: Chihuahua, Chihuahua, México, Consejo de Recursos Minerales, Archivo Técnico 080689, 21 p.

Humphreys, E.D., 1995, Post-Laramide removal of the Farallon slab, western United States: Geology, 23, 987-990.

Huntting, M.T., 1949, Perlite and other volcanic glass occurrences in Washington: Olympia, Washington, Department of Conservation and Development, Division of Mines and Geology, Report of Investigations $17,78 \mathrm{p}$.

Instituto Nacional de Estadística, Geografía e Informática (INEGI), 2005, Carta topográfica Villa Hidalgo H12-B86, escala 1:50000: Aguascalientes, Aguascalientes, México, Instituto Nacional de Geografía e Informática, 1 mapa.

Jaster, M.C., 1956, Perlite Resources of the United States: A Contribution to Economic Geology: Washington, D.C., USA, Geological Survey Bulletin No. 1027-I, 403 p.

Koukouzas, N., Dunham, A., 1994, Genesis of a volcanic industrial rock, trachilas perlite deposit, Milos Island, Greece: Bulletin of the Geological Society of Greece, 30/3, 333-340.

Lagarda-Lagarda, I., 1983, Evaluación geológico-económica de los depósitos de perlita en la Sierra Santa Úrsula, Guaymas, Sonora: Hermosillo, Sonora, México, Universidad de Sonora, tesis profesional, $53 \mathrm{p}$.

Livingston, D.E., 1973, Geology, K-Ar ages and Sr isotopy at La Caridad, Nacozari district, Sonora, Mexico: Tucson, Arizona, USA, University of Arizona, Master thesis, $31 \mathrm{p}$.

Lofgren, G., 1970, Experimental Devitrification Rate of Rhyolite Glass: Geological Society of America Bulletin, 81, 553-560.

Lonsdale, P., 1991, Structural pattern of the pacific floor offshore peninsular California, in Dauphin, J.P., Simoneit, B.R.T. (eds.), The Gulf and the Peninsular Province of the Californias, American Association of Petroleum Geologists, Memoir 47, 87-125.

Marshall, R.R., 1961, Devitrification of natural glass: Geological Society of America Bulletin, 72, 1493-1520.

Maxim, L.D., Niebo, R., McConnell, E.E., 2014, Perlite toxicology and epidemiology - a review: Inhalation Toxicology: International Forum for Respiratory Research, 26, 259-270.

McArthur, A.N., Cas, R.A.F., Orton, G.J., 1998, Distribution and significance of crystalline, perlitic and vesicular textures in the Ordovician Garth Tuff (Wales): Bulletin of Volcanology, 60, 260285.

McDowell, F.W., compiler, 2007, Geologic transect across the northern Sierra Madre Occidental volcanic field, Chihuahua and Sonora, Mexico: Geological Society of America Digital Map and Chart series $6,70 \mathrm{p}$.

McDowell, F.W., Keizer, R.P., 1977, Timing of Mid Tertiary volcanism in the Sierra Madre Occidental between Durango City and Mazatlán, Mexico: Geological Society of America Bulletin, 88, 1479-1487.

McDowell, F.W., Clabaugh, S.E., 1979, Ignimbrites of the Sierra Madre Occidental and their relation to the tectonic history of western Mexico, in Chapin, C.E., Elston, W.E. (eds.), Ash-Flow Tuffs: Geological Society of America Special Paper 180, 113-124.

McDowell, F.W., Roldán-Quintana, J., Amaya-Martínez, R., 1997, Interrelationship of sedimentary and volcanic deposits associated with Tertiary extension in Sonora, Mexico: Geological Society of America Bulletin, 109, 1349-1360.

McDowell, F.W., Roldan-Quintana, J., Connelly, J.N., 2001, Duration of Late Cretaceous-early Tertiary magmatism in east-central Sonora, Mexico: Geological Society of America Bulletin, 113, 521-531.
McQuarrie, N., Wernicke, B.P., 2005, An animated tectonic reconstruction of southwestern North America since $36 \mathrm{Ma}$ : Geosphere, 1, 147-172.

Mendoza-Cordova, A., Bon-Aguilar, C.R., Quevedo-León, A., NevarezDel Castillo, L., 1989, Exploración Preliminar sobre los recursos de minerales no metálicos en el estado de Sinaloa: Culiacán, Sinaloa, Mexico, Consejo de Recursos Minerales, Archivo Técnico, SIGMACRM 250339, 79 p.

Murray, B.P., Busby, C. J., 2015, Epithermal mineralization controlled by synextensional magmatism in the Guazapares Mining District of the Sierra Madre Occidental silicic large igneous province, Mexico: Journal of South American Earth Sciences, 58, 1-18.

Murray, B.P., Busby, C.J., Ferrari, L., Solari, L.A., 2013, Synvolcanic crustal extension during the mid-Cenozoic ignimbrite flare-up in the northern Sierra Madre Occidental, Mexico: Evidence from the Guazapares Mining District region, western Chihuahua: Geosphere, 9, 1-35.

Murray, B.P., Busby, C.J., Verde-Ramírez, M.A., 2015, Extension and magmatism in the Cerocahui basin, northern Sierra Madre Occidental, western Chihuahua, Mexico: International Geology Review, 57, 893-918.

Nourse, J.A., Anderson, T.H., Silver, L.T., 1994, Tertiary metamorphic core complexes in Sonora, northwestern Mexico: Tectonics, 13, 1161-1182.

Orth, K., McPhie, J., 2003, Textures formed during emplacement and cooling of a Palaeoproterozoic, small-volume rhyolitic sill: Journal of Volcanology and Geothermal Research, 128, 341-362.

Palafox-Reyes, J.J., Minjáres-Sosa, I., Monreal-Saavedra, R., AlmazánVázquez, E., Ochoa-Landin, L.H., Rodríguez-Torres, R., RiveraEnríquez, B., Castro-Escárrega, J.J., Zamora-Tovar, R.E., 1998, Carta geológico-minera Nacozari H12-6 Sonora y Chihuahua, 1:250000: Pachuca, Hidalgo, México, Servicio Geológico Mexicano, 1 mapa.

Perlite.org, Perlite Institute: A Worldwide Association of Perlite Professionals. Website: https://perlite.org//, last visited in 02/ February/2016.

Rascón-Heimpel, M.A., Valencia-Moreno, M., Ochoa-Landín, L., Calmus, T., 2012, Geología y geoquímica del pórfido cuprífero Los Alisos, distrito minero de La Caridad, Sonora, México: Revista Mexicana de Ciencias Geológicas, 29, 355-383.

Rodríguez, E., 1961, Informe sobre el Resultado de las Exploraciones por Estaño Diseminado en Coneto de Comonfort, Durango: Mexico D.F., Consejo de Recursos Naturales No Renovables, Archivo Técnico, SIGMA-CRM TI 100002, $23 \mathrm{p}$.

Ross, C.S., Smith, R.L., 1955. Water and other volatiles in volcanic glasses: American Mineralogist, 40, 1071-1089.

Rotella, M., Simandl, G.J., 2004, Marilla Perlite-Volcanic glass occurrence, British Columbia, Canada, in Industrial Minerals with emphasis on Western North America, in Simandl, G.J., McMillan, W.J., Robinson, N. (eds.), British Columbia Ministry of Energy Mines and Petroleum Resources, Paper 2004-2, 265-272.

Sánchez-González, J.A., Ramírez-Evangelista, J.Jr., 1996, Informe Final de la Visita de Reconocimiento al Lote Minero “7 Muro” Municipio de Etzatlan, Jalisco: Guadalajara, Jalisco, Mexico, Consejo de Recursos Minerales, Archivo Técnico 140384, 30 p.

Sánchez-González, J.A., Ramírez-Evangelista, J.Jr., 1997, Informe Final de la Visita de Reconocimiento al Lote "Coyote" Municipio de Zapopan, en el Estado de Jalisco: Guadalajara, Jalisco, Mexico, Consejo de Recursos Minerales, Archivo Técnico 140385, 24 p.

Schmitter, E., 1951, Estudio Preliminar de un Yacimiento de Perlita Uranífera, en la Piedad, Michoacán: Mexico D.F., Instituto de Geología, Laboratorio de mineralogía y Petrografía, Universidad Nacional Autónoma de Mexico, Archivo Técnico SIGMA-CRM TI 160012, $271 \mathrm{p}$.

Secretaria de Programación y Presupuesto (SPP), 1987, Carta Geológica Nacozari H12-6, escala 1:250000: México D.F., Secretaria de Programación y Presupuesto, Coordinación General de los Servicios Nacionales de Estadística, Geografía e Informática, Dirección General de Geografía, 1 mapa. 
Sengul, O., Azizi, S., Karaosmanoglu, F., Tasdemir, M.A., 2011, Effect of expanded perlite on the mechanical properties and thermal conductivity of lightweight concrete: Energy and Buildings 43, 671-676.

Solis-Vorrath, J., 1984, Reconocimiento preliminar al fundo de manganeso y cobre "La Palmita", y al deposito de perlita en el Ejido de Navajas, Municipio de Tala, Estado de Jalisco: Guadalajara, Jalisco, México, Consejo de Recursos Minerales, Archivo Técnico SIGMA-CRM TI 140159, $21 \mathrm{p}$

Staude, G.J.M., Barton, M.D., 2001, Jurassic to Holocene tectonics, magmatism, and metallogeny of northwestern Mexico: Geological Society of America Bulletin, 113, 1357-1374.

Suter, M., 2001, The historical seismicity of northeastern Sonora and northwestern Chihuahua, Mexico $\left(28-32^{\circ} \mathrm{N}, 106-111^{\circ} \mathrm{W}\right)$ : Journal of South American Earth Sciences, 14, 521-532.

Suter, M., 2006, Contemporary studies of the 3 May 1887 Mw 7.5 Sonora, Mexico, Basin and Range Province. Earthquake: Seismological Research Letters, 77, 134-147.

Suter, M., 2008a, Structural configuration of the Teras Fault (Southern Basin and Range Province) and its rupture in the 3 May 1887 MW 7.5 Sonora, Mexico, Earthquake: Revista Mexicana de Ciencias Geológicas, 25, 179-195.

Suter, M., 2008b, Structural configuration of the Otates Fault (Southern Basin and Range Province) and Its Rupture in the 3 May 1887 MW 7.5 Sonora, Mexico, Earthquake: Bulleting of the Seismological Society of America, 98, 2879-2893.

Suter, M., 2015, Rupture of the Pitáycachi Fault in the 1887 Mw 7.5 Sonora, Mexico earthquake (southern Basin-and-Range Province): Rupture kinematics and epicenter inferred from rupture branching patterns: Journal of Geophysical Research Solid Earth, 120, 617-641.

Suter, M., Contreras, J., 2002, Active Tectonics of Northeastern Sonora, Mexico (Southern Basin and Range Province) and the 3 May $1887 M_{\mathrm{w}}$ 7.4 Earthquake: Bulletin of the Seismological Society of America, 92, 581-589.

Tait, M.A, Cas, R.A.F., Viramonte, J.G., 2009, The origin of an unusual tuff ring of perlitic rhyolite pyroclasts: The last explosive phase of the Ramadas Volcanic Centre, Andean Puna, Salta, NW Argentina: Journal of Volcanology and Geothermal Research, 183, 1-16.

Topçu, İ.B., Işikdağ, B., 2007, Manufacture of high heat conductivity resistant clay bricks containing perlite: Building and Environment, 42, 3540-3546.

Topçu, İ.B., Işikdağ, B., 2008, Effect of expanded perlite aggregates on the properties of lightweight concrete: Journal of Material Processing Technology, 204, 34-38.

Torab-Mostaedi, M., Ghaemi, A., Ghassabzadeh, H., Ghannadi-Maraghen, M., 2011, Removal of Strontium and Barium from aqueous solutions by adsorption onto expanded perlite: The Canadian Journal of Chemical Engineering, 89, 1247-1254.

Tuffen, H., Castro, J.M., 2009, The emplacement of an obsidian dyke through thin ice: Hrafntinnuhryggur, Krafla Iceland: Journal of Volcanology and Geothermal Research, 185, 352-366.

Ugalde, H., 1970, Reconocimiento Geológico Evaluatorio del Yacimiento de Perlita El Cerro Pinto Mpo. De Tepeyahualco, Edo. De Puebla: Puebla, Puebla, México, Consejo de Recursos Naturales No Renovables, Archivo Técnico 210131, 9 p.

Ugalde, H., 1975, Aprovechamiento de Rocas Silíceas: Puebla, Puebla, México, Consejo de Recursos Naturales No Renovables, Archivo Técnico SIGMA-CRM TI 210031-1, 16 p.

U.S. Geological Survey (USGS), 2005, Perlite statistics, in Kelly, T.D., Matos, G.R., Historical statistics for mineral and material commodities in the United States: U.S. Geological Survey Data Series 140, available online at <http://minerals.usgs.gov/minerals/ pubs/historical-statistics/perlite-use.pdf $>$, last visited on 8 February 2016.

Valencia-Moreno, M., Ruiz, J., Barton, M.D., Patchett, P.J., Zürcher, L., Hodkinson, D., Roldan-Quintana, J., 2001, A chemical and isotopic study of the Laramide granitic belt of northwestern Mexico: Identification of the southern edge of the North American
Precambrian basement: Geological Society of America Bulletin, 113, 1409-1422.

Vaou, V., Panias, D., 2010, Thermal insulating foamy geopolymers from perlite: Minerals Engineering, 23, 1146-1151.

Vega-Granillo, R., Calmus, T., 2003, Mazatán metamorphic core complex (Sonora, Mexico): structures along the detachment fault ant its exhumation evolution: Journal of South American Earth Sciences, $16,193-204$.

Velasco-Hernández, J., 1976, Yacimientos Minerales del Estado de Michoacán: Michoacán, Michoacán, México, Consejo de Recursos Minerales, Archivo Técnico SIGMA-CRM TI 160107, 254 p.

Vidal-Solano, J.R., Paz-Moreno, F.A., Iriondo, A, Demant, A., Cochemé, J.J., 2005, Middle Miocene peralkaline ignimbrites in the Hermosillo region Sonora, Mexico: Geodynamic implications: C. R. Geoscience, 337, 1421-1430.

Vidal-Solano, J.R., Paz-Moreno, F.A., Demant, A., López-Martínez, M., 2007, Ignimbritas hiperalcalinas del Mioceno medio en Sonora Central: revaluación de la estratigrafía y significado del volcanismo terciario: Revista Mexicana de Ciencias Geológicas, 24, 47-67.

Vidal-Solano, J.R., Demant, A., Paz-Moreno, F.A., Lapierre, H., OrtegaRivera, M.A., Lee, J.K.W, 2008a, Insight into the tectonomagmatic evolution of NW Mexico: geochronology and petrochemistry of the Miocene volcanic sequences from the Pinacate area, Sonora: Geological Society of America Bulletin, 120, 691-708.

Vidal-Solano, J.R., Lapierre, H., Stock, J.M, Demant, A., Paz-Moreno, F.A., Bosch, D., Brunet, P., Amortegui, A, 2008b, Isotope geochemistry and petrogenesis of peralkaline Middle Miocene ignimbrites from central Sonora: relationship with continental break-up and the birth of the Gulf of California: Bulletin de la Société Géologique de France, 179, 453-464.

Vidal-Solano, J.R., Lozano Santa-Cruz, R., Zamora, O., Mendoza-Cordova, A., Stock J.M., 2013, Geochemistry of the extensive peralkaline pyroclastic flow deposit of NW Mexico, based on conventional and handheld X-ray fluorescence. Implications in a regional context: Journal of Iberian Geology, 39, 121-130.

Vidal-Solano, J.R., Hinojosa-García, H., Hinojosa-Prieto, H., 2014a, Caracterización petrológica de las riolitas con perlita y obsidiana en Sonora, México: Implicaciones geológicas para su formación: Geos, 34, 333.

Vidal-Solano, J.R., Reyna, M., Gastelum, J., Hinojosa-García, H., PerezTello, M., Hinojosa-Prieto, H., Escareño-Márquez, P., 2014b, Characterization petrographic, geochemical and thermal gravimetric on some perlite Oligocene deposits in the State of Sonora, Mexico: Contribution to the study of the metallurgical process of expansion: Advances in Minerals and Materials Engineering, 1, 330-344.

Villalobos-Escobar, G.P., Castro, R.R., 2015, Estimation of Local Magnitude in Northeastern Sonora, Mexico, Using Empirical Relations Based on Recorded Duration: Seismological Research Letters, 86, 870-875.

Vivanco-Flores, E., 1978, Exploración Geológico-Geoquímico, en Loma El Cristo Municipio de San Felipe del Progreso, Estado de México: Michoacán, Michoacán, México, Consejo de Recursos Minerales, Archivo Técnico SIGMA-CRM TI 150187, 20 p.

White, M.J., McPhie, J, 1997, A submarine welded ignimbrite-crystalrich sandstone facies association in the Cambrian Tyndall Group, western Tasmania, Australia: Journal of Volcanology and Geothermal Research, 76, 277-295.

Wilson, J.L., Emmons, D.L., 1985, The Tucker Hill perlite deposit, Lake County, Oregon: Mining Engineering, Technical Papers, 1301-1308.

Wong, M.S., Gans, P.B., Scheier, J., 2010, The ${ }^{40} \mathrm{Ar} /{ }^{39} \mathrm{Ar}$ thermochronology of core complexes and other basement rocks in Sonora, Mexico: Implications for Cenozoic tectonic evolution of northwestern Mexico. Journal of Geophysical Research, 115, B07414, 1-19.

Woodcock, N.H., Mort, K., 2008, Classification of fault breccias and related fault rocks: Geological Magazine (Rapid Communication), $145,435-440$.

Worcester, P., 1976, Geology of northern part of the Nacozari mining district, Nacozari, Sonora, Mexico: Oxford, Ohio, USA, The Miami 
University of Ohio, PhD thesis, $242 \mathrm{p}$.

Yamagishi, H., Dimroth, E., 1985, A comparison of Miocene and Archean Rhyolite hyaloclastites: Evidence for a hot and fluid rhyolite lava: Journal of Volcanology and Geothermal Research, 23, 337-355.

Zielinski, R.A., 1978, Uranium abundances and distribution in associated glassy and crystalline rhyolites of the western United States: Geological Society of America Bulletin, 89, 409-414.
Zukowski, M., Haese, G., 2010, Experimental and numerical investigation of a hollow brick filled with perlite insulation: Energy and Buildings, 42, 1402-1408.

Manuscript received: October 10, 2014

Corrected manuscript received: August 6, 2015

Manuscript accepted: August 8, 2015

\section{Supplementary Figures}

\section{Applications of Perlite}

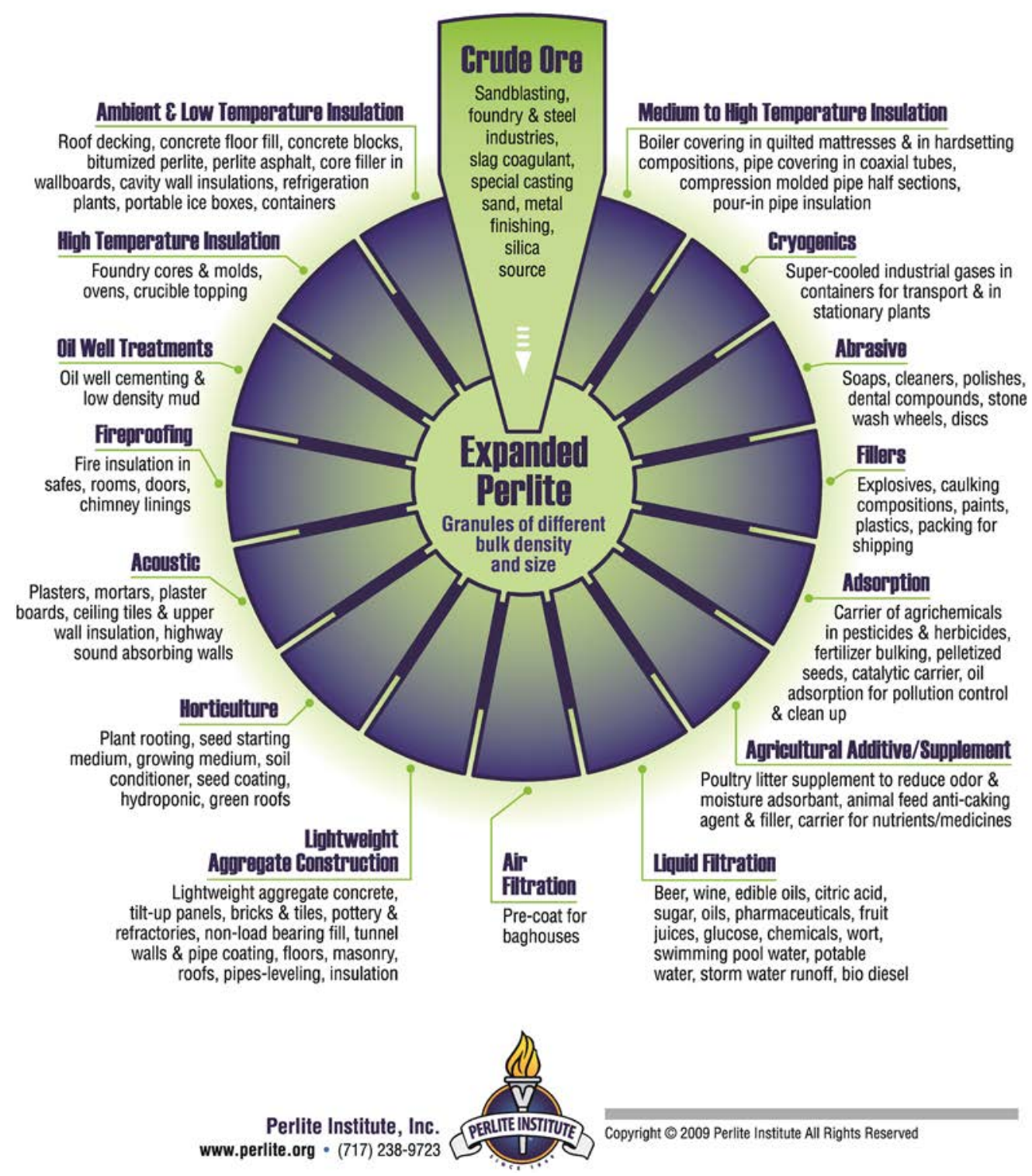

Figure S.1. Industrial applications of expanded perlite. Printed with permission from the Perlite Institute, Inc. (available at https://perlite.org/libraryperlite-info/general-info/PerliteWheel.pdf). 
(A)
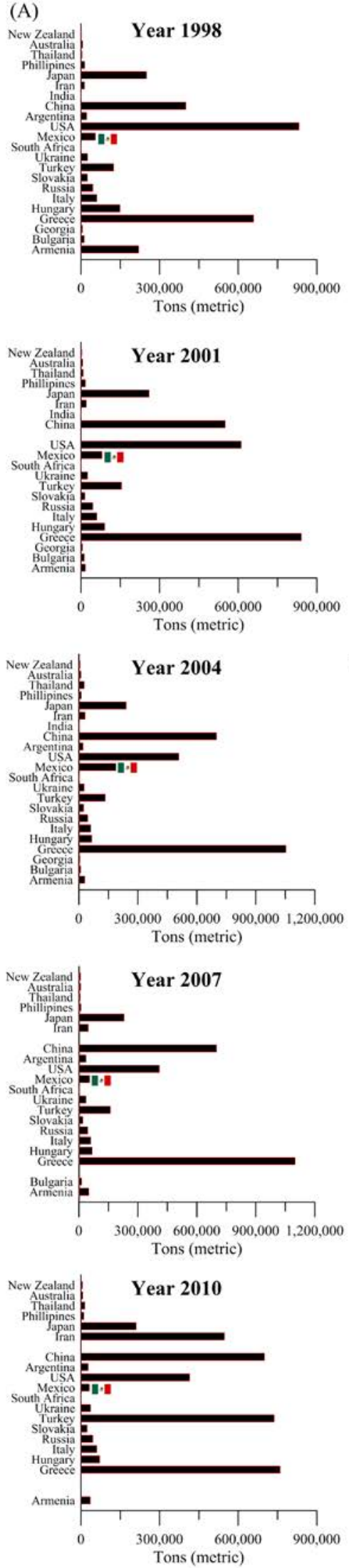
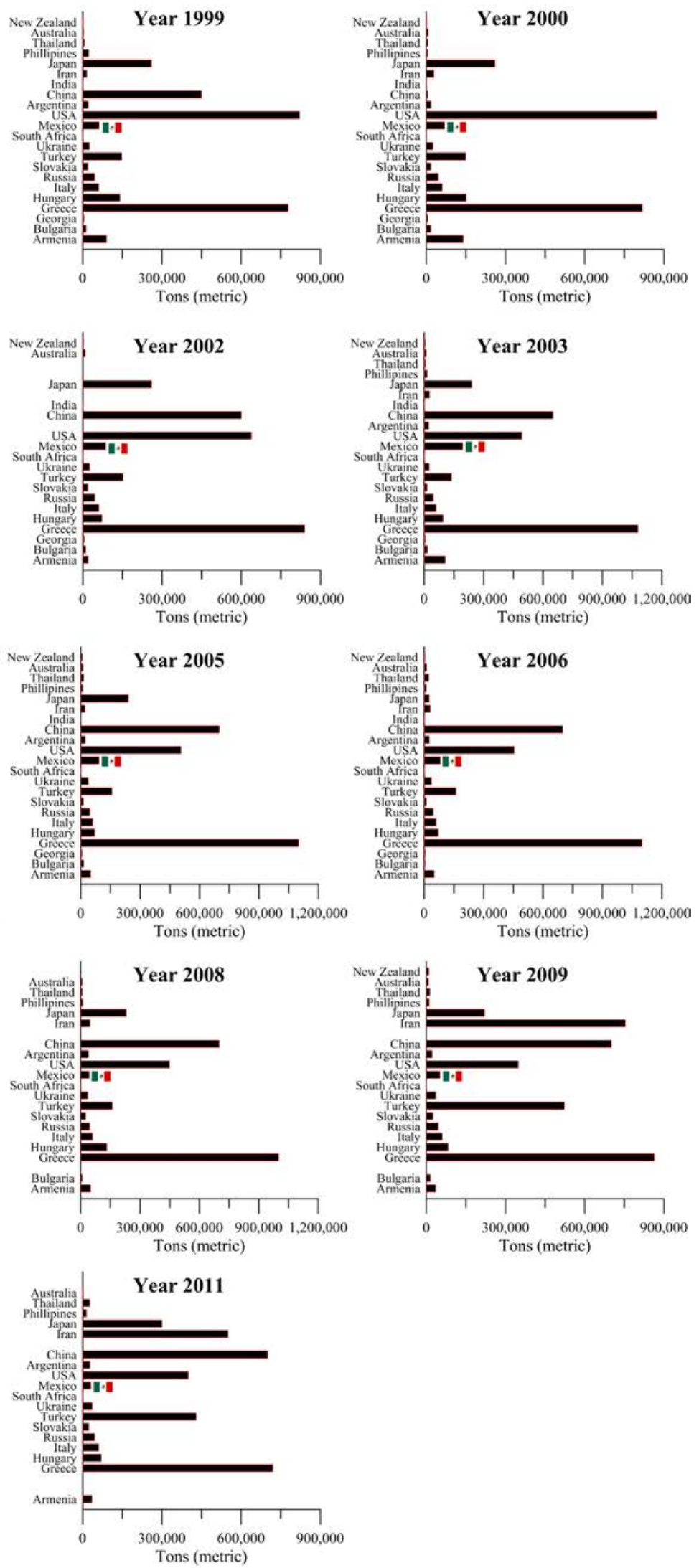

Figure S.2.A. World production of expanded perlite (in metric Tons) according to the British Geological Survey (BGS, 2004, 2007, 2010) and Bide et al. (2014) at the BGS for the years 1998 to 2011 (A) and the U.S. Geological Survey (USGS, 2005) and Bolen (2000, 2011a, 2011b, 2014, 2015) at the USGS for the years 1996 to 2014 (B). 

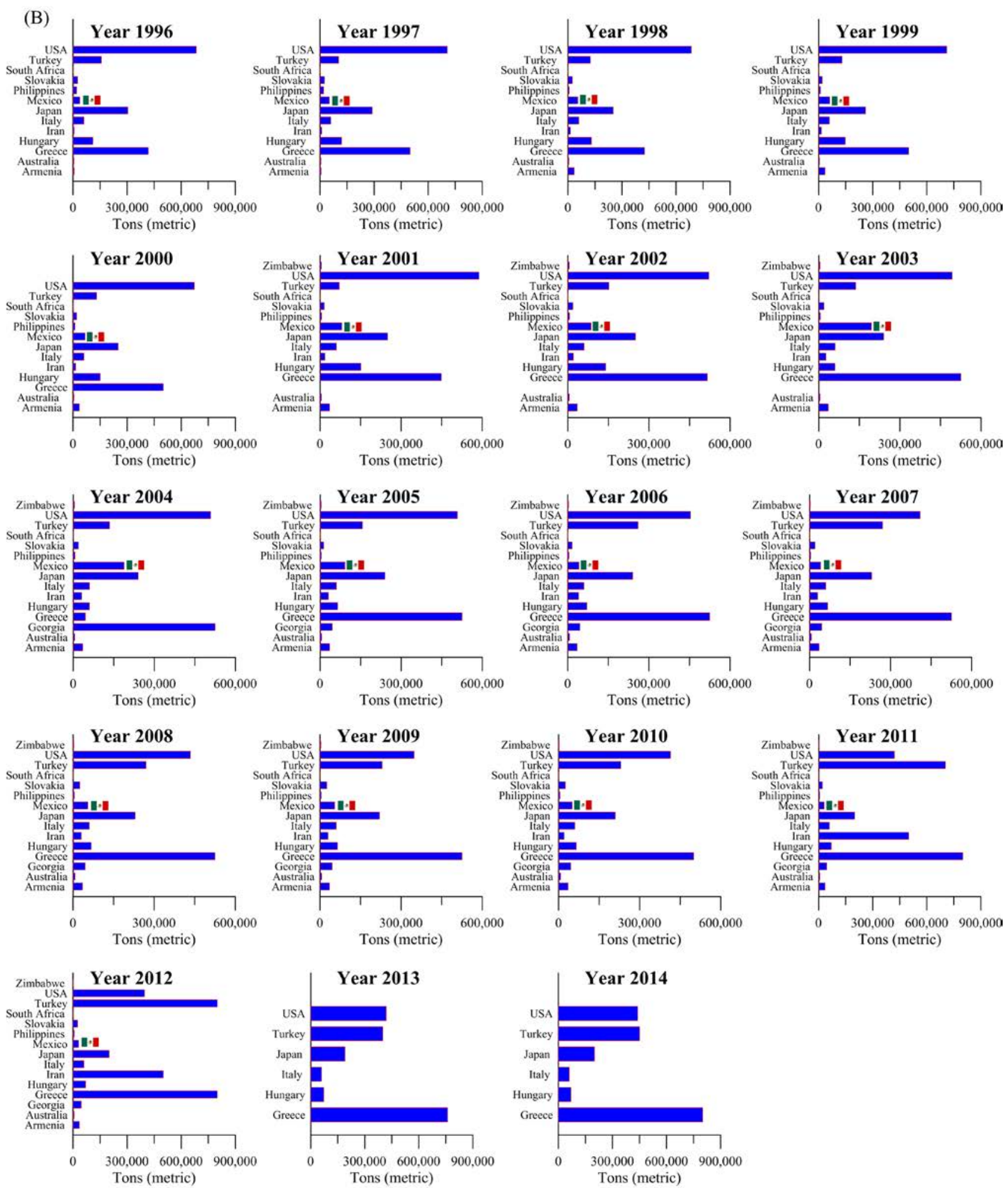

Figure S.2.B. World production of expanded perlite (in metric Tons) according to the British Geological Survey (BGS, 2004, 2007, 2010) and Bide et al. (2014) at the BGS for the years 1998 to 2011 (A) and the U.S. Geological Survey (USGS, 2005) and Bolen (2000, 2011a, 2011b, 2014, 2015) at the USGS for the years 1996 to 2014 (B). 


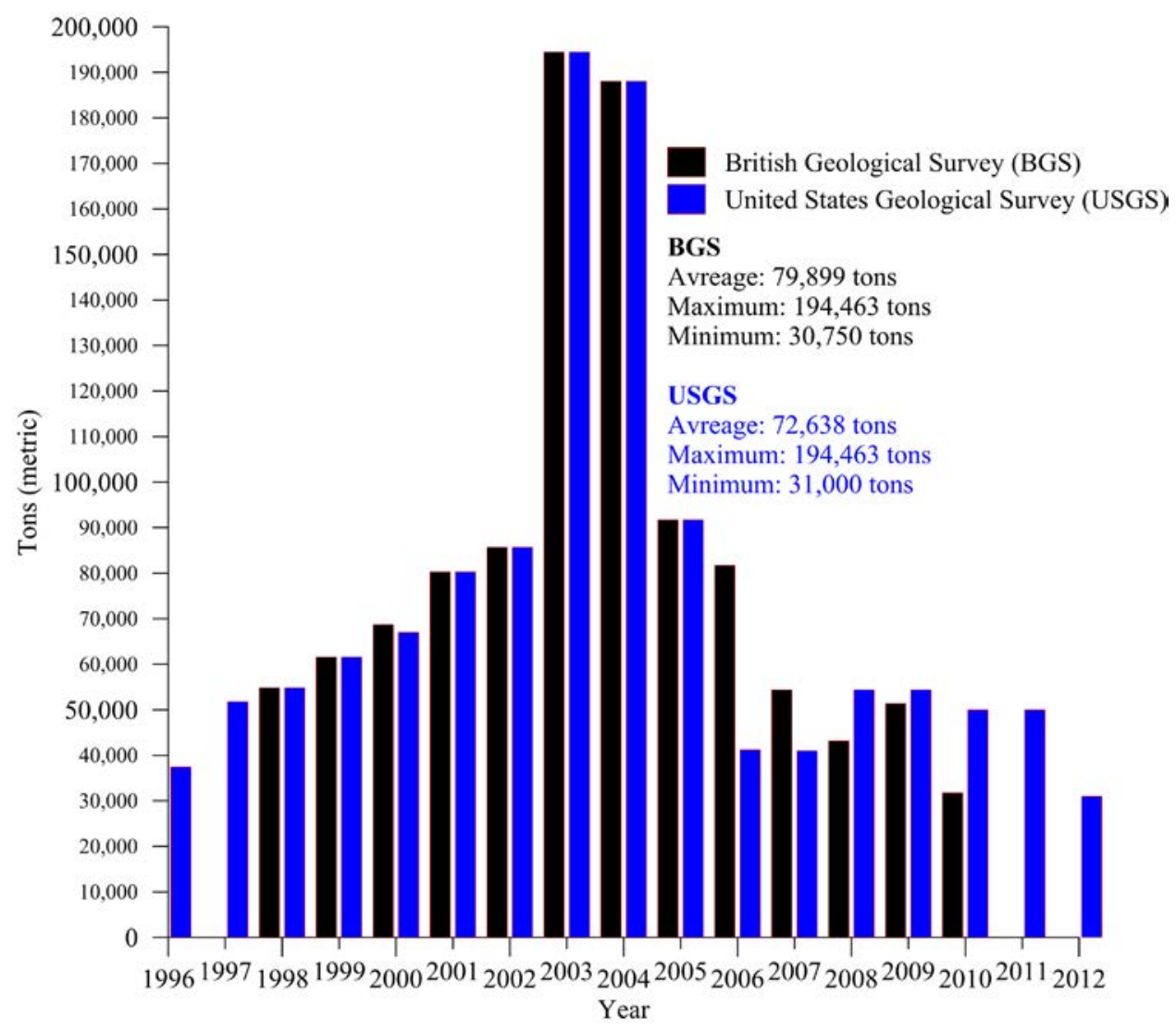

Figure S.3. Mexican production of expanded perlite (in metric Tons) according to the British Geological Survey (BGS, 2004, 2007, 2010) and Bide et al. (2014) at the BGS for the years 1998 to 2010, and the U.S. Geological Survey (USGS, 2005) and Bolen (2000, 2011a, 2011b, 2014, 2015) at the USGS for the years 1996 to 2012 . 